\title{
Effect of the Cedar River on the Quality of the Ground-Water Supply for Cedar Rapids, lowa
}

\section{By PETER M. SCHULMEYER}

U.S. GEOLOGICAL SURVEY

Water-Resources Investigations Report 94-4211

Prepared in cooperation with the

CITY OF CEDAR RAPIDS, IOWA

lowa City, lowa

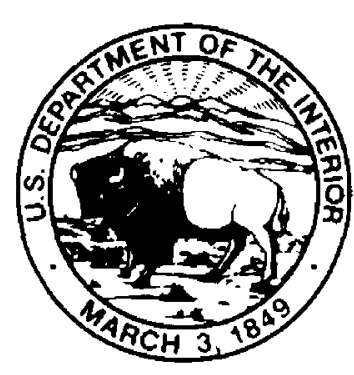

1995 


\title{
U.S. DEPARTMENT OF THE INTERIOR \\ BRUCE BABBITT, Secretary
}

\author{
U.S. GEOLOGICAL SURVEY \\ GORDON P. EATON, Director
}

For additional information write to:

Copies of this report can be purchased from:

U.S. Geological Survey

Earth Science Information Center

District Chief

U.S. Geological Survey

Open-File Reports Section

P.O. Box 1230

Box 25286, MS 517

lowa City, lowa 52240

Denver Federal Center

Denver, Colorado 80225 


\section{CONTENTS}

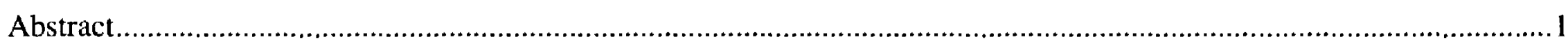

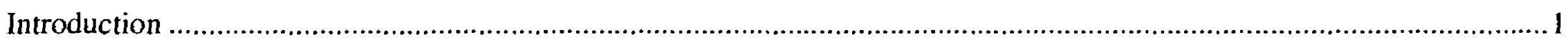

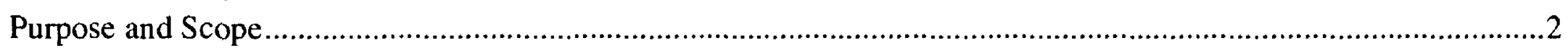

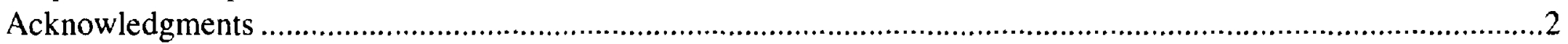

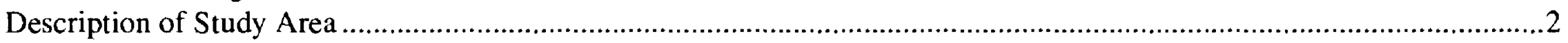

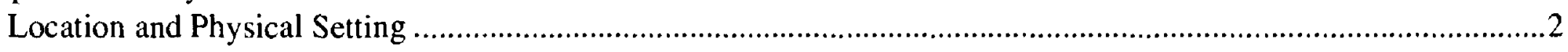

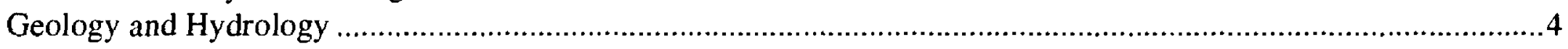

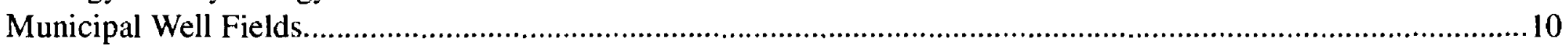

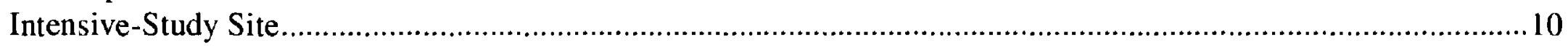

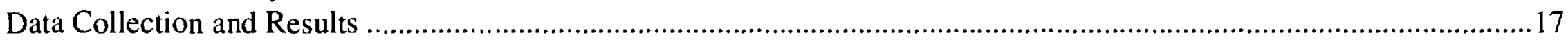

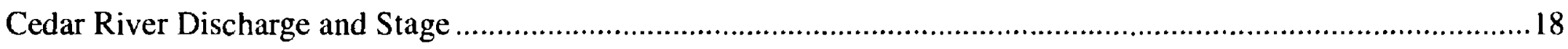

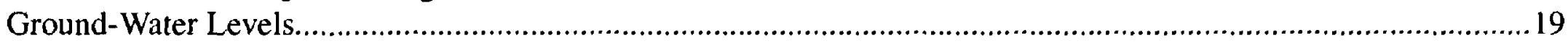

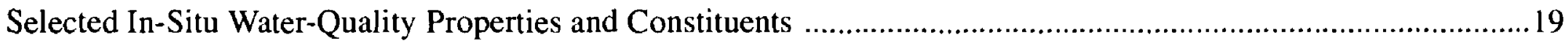

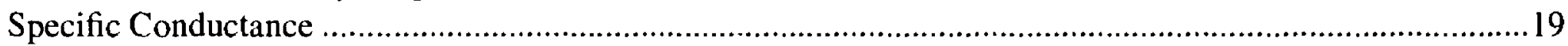

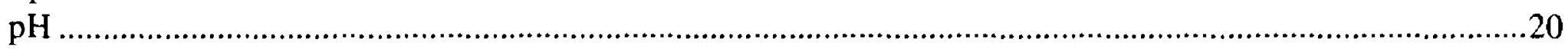

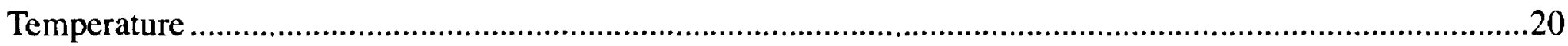

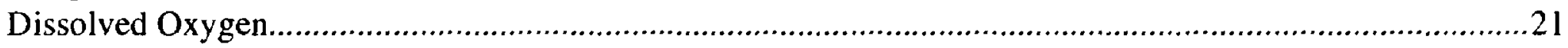

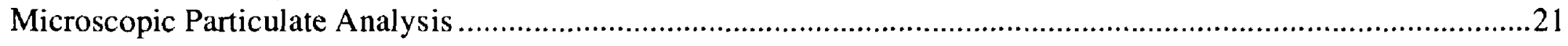

Effect of the Cedar River on Selected Water-Quality Properties and Constituents of the Alluvial Aquifer......................24

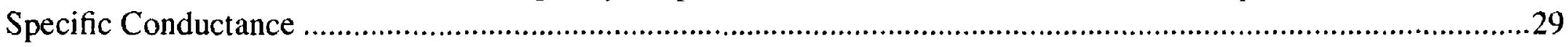

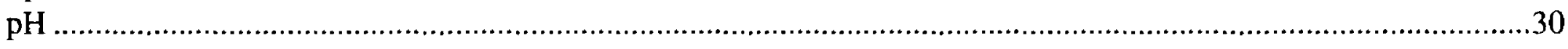

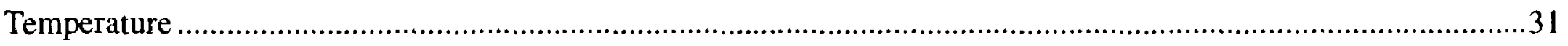

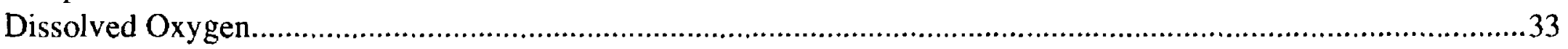

Assessment of Relative Risk of Alluvial Aquifer to Contamination by Pathogens .....................................................36

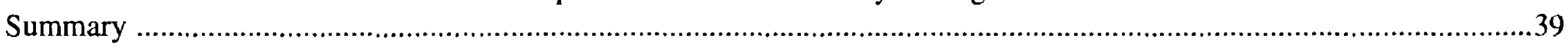

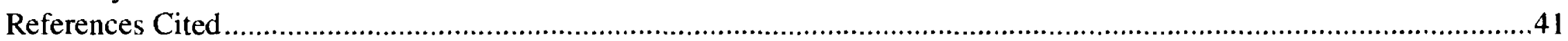

\section{FIGURES}

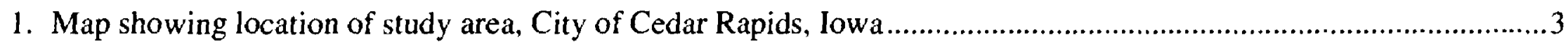

2-5. Lithologic section:

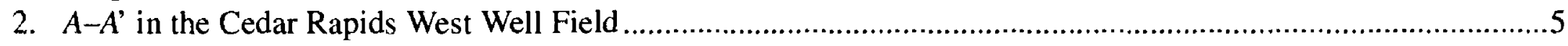

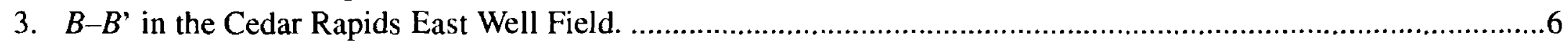

4. $C-C^{\prime}$ in the Cedar Rapids Seminole Well Field....................................................................................

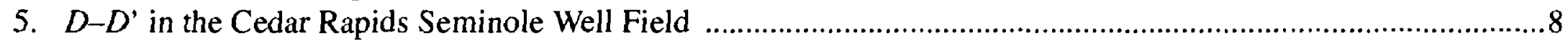

6-7. Maps showing:

6. Location of municipal wells and traces of lithologic sections $A-A^{\prime}$ and $B-B^{\prime}$ in the Cedar Rapids East and West Well Fields ...............................................................................................................

7. Location of municipal wells and traces of lithologic sections $C-C^{\prime}$ and $D-D$ ' in Cedar Rapids Seminole

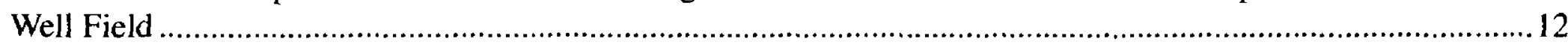

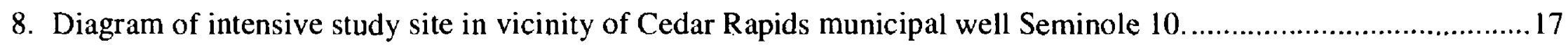

9. Daily mean discharge of the Cedar River at Cedar Rapids and collection dates of samples for microscopic particulate analysis, October 1992 through January 1994.

10-20. Graphs showing:

10. Water levels in the Cedar River, Cedar Rapids municipal well Seminole 10, and observation wells CRM-3 and CRM-4, February 1, 1993, through January 31, 1994.

11. Specific conductance and discharge for the Cedar River at Cedar Rapids gaging station from February 20 through April 29 and June 25 through August 30, 1993. 


\section{FIGURES-Continued}

12. $\mathrm{pH}$ and discharge of the Cedar River at Cedar Rapids gaging station from February 20 through April 29, 1993

13. Dissolved oxygen and discharge of the Cedar River at Cedar Rapids gaging station from February 20 through April 30 and June 25 through August 30, 1993

14. Specific conductance of water from the Cedar River, observation well CRM-4, and Cedar Rapids municipal well Seminole 10, and estimated traveltimes of water from the river to observation well CRM-4 and municipal well Seminole 10, February 1, 1993, through January 31, 1994 ...

15. Specific conductance of water from the Cedar River, observation well CRM-3, and the municipal watertreatment plant, February 1, 1993, through January 31, 1994

16. $\mathrm{pH}$ of water from the Cedar River, observation wells CRM-3 and CRM-4, and Cedar Rapids municipal well Seminole 10, February 1, 1993, through January 31, 1994

17. Temperature of water from the Cedar River, observation well CRM-4, and Cedar Rapids municipal well Seminole 10 , and estimated traveltimes of water from the river to observation well CRM-4 and municipal well Seminole 10, February 1, 1993, through January 31, 1994

18. Temperature of water from the Cedar River, observation well CRM-3, and the municipal water-treatment plant, and estimated traveltimes of water from the river to observation well CRM-3, February 1, 1993, through January 31, 1994

19. Concentrations of dissolved oxygen in water from the Cedar River, observation well CRM-4, and Cedar Rapids municipal well Seminole 10, and estimated traveltimes for water from the river to observation well CRM-4 and municipal well Seminole 10, February 1, 1993, through January 31, 1994

20. Concentrations of dissolved oxygen in water from the Cedar River, observation well CRM-3, and the Cedar Rapids municipal water-treatment plant, February 1, 1993, through January 31, 1994

\section{TABLES}

1. Hydraulic properties for alluvial aquifer into which Cedar Rapids municipal wells are completed

2. Construction information for municipal water wells, test holes, and observation wells in the vicinity of Cedar Rapids, Iowa

3. Results of microscopic particulate analysis for primary indicators in water from study area, December 1992 through November 1993

4. Results of microscopic particulate analysis for secondary indicators in water from study area, December 1992 through November 1993

5. Results of microscopic particulate analysis for selected water-quality properties and selected secondary indicators in water from study area, December 1992 through November 1993

6. Risk of surface-water contamination as determined by microscopic particulate analysis of water in the study area, December 1992 through November 1993

7. Filtration efficiency calculated as a log-reduction rate between the Cedar River and selected municipal wells and the Cedar Rapids municipal water-treatment plant, December 1992 through November 1993

8. Mean daily water levels in the Cedar River at the surface-water monitoring site, February 1, 1993, through January 31, 1994

9. Mean daily water levels in observation well CRM-4, February 1, 1993, through January 31, 1994.

10. Mean daily water levels in municipal well Seminole 10, February 1, 1993, through January 31, 1994.

11. Mean daily water levels in observation well CRM-3, February 1, 1993, through January 31, 1994.

12. Water-level measurements for observation wells CRM-3, CRM-4, and CRM-6, February 1993 through January 1994

13. Mean daily specific conductance of water from the Cedar River, surface-water monitoring site, February 1, 1993 , through January 31, 1994

14. Mean daily specific conductance of water from observation well CRM-4, February 1, 1993, through January 31,1994

15. Mean daily specific conductance of water from municipal well Seminole 10, February 1,1993, through January 31, 1994

16. Mean daily specific conductance of water from observation well CRM-3, February 1, 1993, through January 31, 1994 


\section{TABLES-Continued}

17. Mean daily specific conductance of water from the Cedar Rapids municipal water-treatment plant, February 1, 1993, through January 31, 1994 ...

18. Mean daily $\mathrm{pH}$ of water from the Cedar River, surface-water monitoring site, February 1, 1993, through January 31,1994

19. Mean daily $\mathrm{pH}$ of water from observation well CRM-4, February 1, 1993, through January 31, 1994....................54

20. Mean daily $\mathrm{pH}$ of water from municipal well Seminole 10, February 1,1993 , through January $31,1994 \ldots \ldots \ldots \ldots . . .55$

21. Mean daily $\mathrm{pH}$ of water from observation well CRM-3, February 1, 1993, through January 31, 1994.....................56

22. Mean daily $\mathrm{pH}$ of water from the Cedar Rapids municipal water-treatment plant, February 1, 1993, through January 31, 1994.

23. Mean daily temperature of water from the Cedar River, surface-water monitoring site, February 1, 1993, through January $31,1994 \ldots$

24. Mean daily temperature of water from observation well CRM-4, February 1, 1993, through January 31, $1994 \ldots . . . .59$

25. Mean daily temperature of water from municipal well Seminole 10, February 1, 1993, through January $31,1994 \ldots 60$

26. Mean daily temperature of water from observation well CRM-3, February 1, 1993, through January $31,1994 \ldots \ldots . .61$

27. Mean daily temperature of water from the Cedar Rapids municipal water-treatment plant, February 1, 1993, through January 31, 1994

28. Mean daily concentration of dissolved oxygen in water from the Cedar River, surface-water monitoring site, February 1, 1993, through January 31, 1994

29. Mean daily concentrations of dissolved oxygen in water from observation well CRM-4, February 1, 1993, through January 31, 1994

30. Mean daily concentration of dissolved oxygen in water from municipal well Seminole 10, February 1, 1993, through January 31, 1994

31. Mean daily concentrations of dissolved oxygen in water from observation well CRM-3, February 1, 1993, through January 31, 1994

32. Mean daily concentrations of dissolved oxygen in water from the Cedar Rapids municipal water-treatment plant, February 1, 1993, through January 31, 1994

33. Numerical range of each primary bio-indicator counted per 100 gallons of water.

34. Relative surface-water risk factors associated with scoring of primary bio-indicators present during microscopic particulate analysis of water from study area.

\section{CONVERSION FACTORS, ABBREVIATIONS, AND VERTICAL DATUM}

\begin{tabular}{rcl} 
Multiply & By & To obtain \\
\hline inch (in.) & 25.4 & millimeter \\
foot $(\mathrm{ft})$ & 0.3048 & meter \\
mile $(\mathrm{mi})$ & 1.609 & kilometer \\
square mile $\left(\mathrm{mi}^{2}\right)$ & 2.590 & square kilometer \\
gallon $(\mathrm{gal})$ & 3.785 & liter \\
million gallons $(\mathrm{Mgal})$ & 3,785 & cubic meter \\
million gallons per day $(\mathrm{Mgal} / \mathrm{d})$ & 3,785 & cubic meter per day \\
gallon per minute $(\mathrm{gal} / \mathrm{min})$ & 0.00006309 & cubic meter per second \\
foot per day $(\mathrm{ft} / \mathrm{d})$ & 0.3048 & meter per day \\
foot squared per day $\left(\mathrm{ft}^{2} / \mathrm{d}\right)$ & 0.09290 & meter squared per day \\
cubic foot per second $\left(\mathrm{ft}^{3} / \mathrm{d}\right)$ & 0.02832 & cubic meter per second \\
gallon per day per foot $[(\mathrm{gal} / \mathrm{d}) / \mathrm{ft}]$ & 0.01242 & cubic meter per day per meter \\
gallon per minute per foot $[(\mathrm{gal} / \mathrm{min}) / \mathrm{ft})$ & 0.2070 & liter per second per meter
\end{tabular}

Temperature in degrees Fahrenheint $\left({ }^{\circ} \mathrm{F}\right)$ may be converted to degrees Celsius $\left({ }^{\circ} \mathrm{C}\right)$ as follows:

degree Fahrenheit $\left({ }^{\circ} \mathrm{F}\right) \quad \quad{ }^{\circ} \mathrm{C}=\left({ }^{\circ} \mathrm{F}-32\right) / 1.8 \quad$ degree Celsius $\left({ }^{\circ} \mathrm{C}\right)$

Sea level: In this report, "sea level" refers to the National Geodetic Vertical Datum of 1929 (NGVD of 1929)--a geodetic datum derived from a general adjustment of the firstorder level nets of both the United States and Canada, formerly called Sea Level Datum of 1929. 


\title{
Effect of the Cedar River on the Quality of the Ground-Water Supply for Cedar Rapids, lowa
}

\author{
By Peter M. Schulmeyer
}

\section{Abstract}

The Surface Water Treatment Rule under the 1986 Amendment to the Safe Drinking Water Act requires that public-water supplies be evaluated for susceptibility to surface-water effects. The alluvial aquifer adjacent to the Cedar River is evaluated for biogenic material and monitored for selected water-quality properties and constituents to determine the effect of surface water on the water supply for the City of Cedar Rapids, Iowa. Results from monitoring of selected water-quality properties and constituents showed an inverse relation to river stage or discharge. Water-quality properties and constituents of the alluvial aquifer changed as water flowed from the river to the municipal well as a result of drawdown. The values of specific conductance, $\mathrm{pH}$, temperature, and dissolved oxygen at observation well CRM- 4 and municipal well Seminole 10 generally follow the trends of values for the Cedar River. Values at observation well CRM-3 and the municipal water-treatment plant showed very little correlation with values from the river. The traveltime of water through the aquifer could be an indication of the susceptibility of the alluvial aquifer to surface-water effects. Estimated traveltimes from the Cedar River to municipal well Seminole 10 ranged from 7 to 17 days.

Above-normal streamflow and precipitation during the study could have increased the effect the river had on the alluvial aquifer and on the possibility of contamination by a pathogen. Microscopic particulate analysis of 29 samples found no Giardia cysts or Crytosporidium oocysts in water collected from municipal wells. Data also indicate that the aquifer is filtering out large numbers of algae, diatoms, rotifers, and nematodes as well as filtering out Cryptosporidium, Giardia, and other protozoa. The number of algae, diatoms, rotifers, protozoa, and vegetative debris for selected municipal wells tested showed at least a reduction to 1 per 1,000 of the number found in the river. A relative risk factor and a log-reduction rate were determined for the aquifer in the vicinity of selected wells. One municipal well had a high-risk factor, three other wells had a moderate-risk factor, and four wells had a low-risk factor. The filtering efficiency of the aquifer is equivalent to a 3 log-reduction rate or 99.99-percent reduction in particulates.

\section{INTRODUCTION}

Enactment of the 1986 Amendment to the Safe Drinking Water Act prompted a new regulation for public-water systems that use surface water or ground water that is directly affected by surface water and is referred to as "ground water under the direct influence of surface water (GWUDI)." This regulation, called the Surface Water Treatment Rule (SWTR) (U.S. Environmental Protection Agency, 1989), declares that States have primary responsibility for identifying GWUDI's and their risk pertaining to waterborne diseases such as giardiasis (Vasconcelos and Harris, 1992) or cryptosporidiosis. From January 1991 to December 1992 seven outbreaks of such diseases were caused by protozoan origin, as reported by Morbidity and Mortality Weekly Report (Last, 1994). Four outbreaks were caused by Giardia with 123 cases reported, and three outbreaks were caused by Cryptosporidium with 3,551 cases reported (Last, 
1994). Both Giardia and Cryptosporidium are protozoan parasites that can reside in the digestive tracks of vertebrates. These parasites may pass into surface water from the fecal material of animals or by surfacewater runoff washing this material into streams or pools. Ground water can become contaminated if these parasites move with the surface water into a ground-water flow system.

Alluvial aquifers adjacent to large streams are an important source of ground water for many municipalities as a source of drinking water. The alluvial aquifer adjacent to the Cedar River, used by Cedar Rapids, Iowa, as a source of water supply, has tentatively been evaluated as GWUDI. GWUDI is defined as any water beneath the surface of the ground with either a significant occurrence of insects, other microorganisms, algae, organic debris, or largediameter pathogens such as Giardia lamblia, or significant and relatively rapid changes in waterquality properties such as specific conductance, $\mathrm{pH}$, temperature, or turbidity that closely correlate to climatological or surface-water conditions (U.S. Environmental Protection Agency, 1989). A cooperative study between the City of Cedar Rapids, Iowa, and the U.S. Geological Survey (USGS) was undertaken to quantify the effect of the Cedar River on water quality of the adjacent alluvial aquifer. Results of this study will aid in an improved understanding of surface-water effects on ground water in alluvial systems.

Determining the effect that the Cedar River has on the alluvial aquifer required a review of departmental and public-water-system records; inspection of wells and their construction records; and an evaluation of the water source, which involved microscopic particulate analysis (MPA) and monitoring of selected water-quality properties and constituents. The MPA evaluates ground-water samples for surface-water indicators such as Giardia, coccidia, diatoms, algae, insects, rotifers, vegetative debris, amorphous debris, pollen, spores, nematodes, crustaceans, amoeba, and protozoa. Evaluation of selected water-quality properties and constituents involves measuring the specific conductance, $\mathrm{pH}$, temperature, and dissolved oxygen in the alluvial aquifer and the Cedar River. If similar changes occur in the alluvial aquifer adjacent to the Cedar River, this could indicate that the ground water is directly affected by surface water and, therefore, is GWUDI.

\section{Purpose and Scope}

This report describes the hydrologic and biogenic information collected from December 1992 through January 1994 to determine the effect of surface water from the Cedar River on water quality in the adjacent alluvial aquifer. Selected water-quality properties and constituents (specific conductance, $\mathrm{pH}$, temperature, and dissolved oxygen) of the Cedar River were compared with those measured in the alluvial aquifer and the Cedar Rapids municipal watertreatment plant, and the biogenic particulates in samples collected from the Cedar River were compared with samples collected from selected municipal wells in the alluvial aquifer and the water system as a whole.

\section{Acknowledgments}

The assistance of city officials and other personnel of the City of Cedar Rapids in well drilling, sample and data collection, and providing well information is here acknowledged and appreciated.

\section{DESCRIPTION OF STUDY AREA}

\section{Location and Physical Setting}

The study area is located in northwest Cedar Rapids, along the Cedar River in Linn County, eastcentral Iowa (fig. 1). The study area encompasses the East, Seminole, and West Well Fields that supply water to the City. There is a well-developed stream pattern that drains into the Cedar River, the largest tributary of the Iowa River. The river flows in a northwest-to-southeast direction through the study area (fig. 1). Approximately $1 \mathrm{mi}$ southeast of the East Well Field is a low-head dam (fig. 1). This is used for flood control, to generate hydroelectric power, and to maintain river stage to provide a source of additional recharge to the well fields, especially during periods of below-normal streamflow.

The Cedar River drainage basin upstream of the gage at Cedar Rapids has a surface area of $6,510 \mathrm{mi}^{2}$. Land use in the Cedar River Basin is predominantly agricultural ( 81 percent), with the major crops being corn and soybeans (U.S. Department of Agriculture, 1976). Annual precipitation ranges from 30 to 36 in., and seasonal temperatures vary from summer highs of 


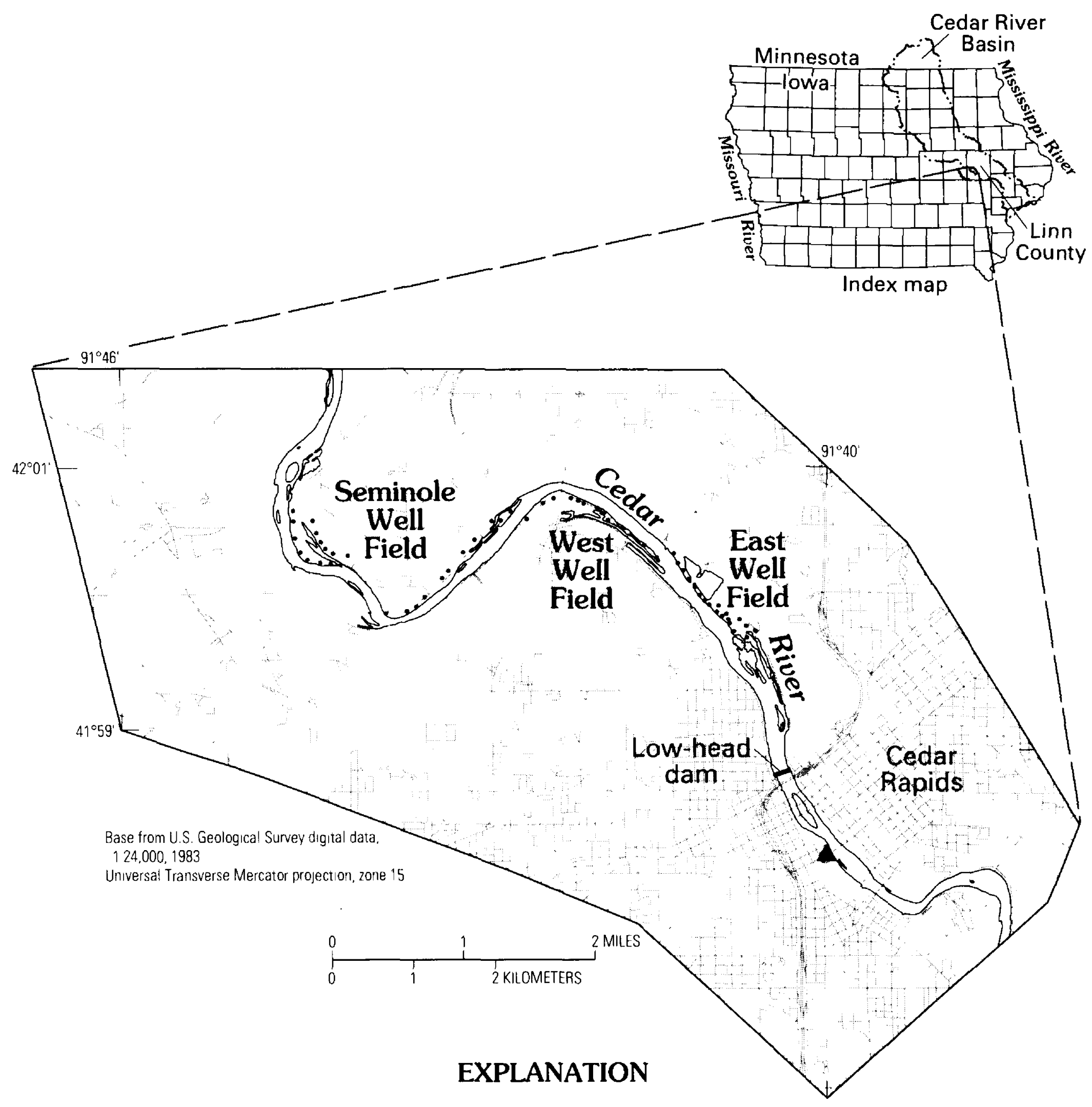

- Streamflow-gaging station

- Municipal well

Figure 1. Location of study area, city of Cedar Rapids, lowa. 
$100^{\circ} \mathrm{F}$ to winter lows of $-18^{\circ} \mathrm{F}$ (Iowa Department of Environmental Quality, 1976).

The City of Cedar Rapids had a population of 108,751 in 1990 and has a steadily increasing demand for water (Bob Glass, City of Cedar Rapids Water Department, oral commun., 1994). There are 53 municipal wells that provide water for public and industrial needs. Pumpage from municipal wells was $8,487 \mathrm{Mgal}$ in $1980,9,118 \mathrm{Mgal}$ in 1990 , and $10,385 \mathrm{Mgal}$ in 1992 ; the reporting period is from July 1 of the previous year through June 30 of the reporting year (Bob Glass, City of Cedar Rapids Water Department, oral commun., 1994).

\section{Geology and Hydrology}

Carbonate rock of Silurian and Devonian age comprise the bedrock aquifer, which is the most widely used aquifer in Linn County for industrial and domestic supply (Hansen, 1970). Overlying the bedrock is a layer of unconsolidated glacial till, loess, and alluvium. The thickness of this layer is variable, with a maximum thickness of $86 \mathrm{ft}$ in the study area as interpreted from seismic refraction information. The alluvial deposits that underlie the flood plain and terraces of the Cedar River form the principal alluvial aquifer in the county. For a more detailed discussion of the geology of the area refer to Hansen (1970) and Prior (1991).

The Cedar River is a meandering stream that has cut into the bedrock surface, exposing steep valley walls in the study area. The flood plain is approximately 3,500 ft wide near the Seminole Well Field and narrows to $1,200 \mathrm{ft}$ near the West Well Field. The fluvial deposits in the study area show typical pointbar sedimentation. Tabular deposits of alluvial material commonly have resulted from the lateral migration of the channel across the flood plain. Deposits of this type typically have an upward diminution of grain size (Reading, 1978). Driller's logs for most of the 53 municipal wells confirm this upward fining of material in the alluvial aquifer. Coarse-grained sand and gravel are found at the base of the alluvium. These grade into coarse- to fine-grained sand in the middle of the unit, with fine-grained sand, silt, and clay near the top. Cobbles and boulders are most prevalent at the East Well Field as noted in drillers logs.

Lithologic sections for the alluvial aquifer were developed using drillers logs (figs. 2, 3, 4, and 5) and show a typical vertical succession of grain size from coarse sand and gravel at the base of the section to fine sand, silt, and clay at the top. Coarse sand and gravel are the most permeable of the materials present in the alluvial aquifer and, where they are thick, can provide the greatest potential for large yields of water (Hansen, 1970).

The alluvial aquifer is hydraulically connected to the Cedar River, bedrock, and upland areas in the study area. Recharge to the alluvial aquifer occurs as infiltration of precipitation, seepage from adjacent aquifers, and from the river when the stage is higher than the ground-water level (Wahl and Bunker, 1986). Normally, the alluvial aquifer receives enough recharge to maintain the water table above the stage of the river (Hansen, 1970). When the river stage is lower than the water table, the aquifer discharges into the river. The Cedar River can receive as much as 80 percent of its annual discharge from ground-water contribution (Squillace, Liszewski, and Thurman, 1993).

Alluvial aquifers can have large transmissivities and hydraulic conductivities, which makes them very desirable for water supplies because large amounts of water can be withdrawn. Hansen (1970) reported a maximum transmissivity of $150,000(\mathrm{gal} / \mathrm{d}) / \mathrm{ft}$ for a storage coefficient of 0.1 for the alluvial aquifer of the East and West Well Fields. The hydraulic conductivity for sand and gravel generally ranges from 2.8 to $2,834 \mathrm{ft} / \mathrm{d}$ (Freeze and Cherry, 1979). Single-well hydraulic tests performed on the alluvial aquifer south of Cedar Rapids produced results ranging from 2.0 to $174.0 \mathrm{ft} / \mathrm{d}$ (Paul Squillace, USGS, written commun., 1994).

Specific capacity depends on both the hydraulic characteristics of the aquifer and construction of the well. Specific capacities for municipal wells, reported by the City of Cedar Rapids, are presented in table 1. Using a modified Theis equation, transmissivity can be calculated using the specific capacity of a well (Heath, 1987). Transmissivities for the alluvial aquifer in the vicinity of municipal well locations were calculated using this method and range from 1,543 to $19,240 \mathrm{ft}^{2} / \mathrm{d}$ (table 1). Hydraulic conductivities at each well location (table 1) were calculated by dividing the transmissivity by the thickness of saturated material and range from 21.3 to $315.2 \mathrm{ft} / \mathrm{d}$.

Fifteen wells are completed in a portion of the alluvial aquifer that has a transmissivity greater than $10,000 \mathrm{ft}^{2} / \mathrm{d}$. All of the wells are set close to the river. Except for municipal wells Seminole 9 and 10, West 9 , 


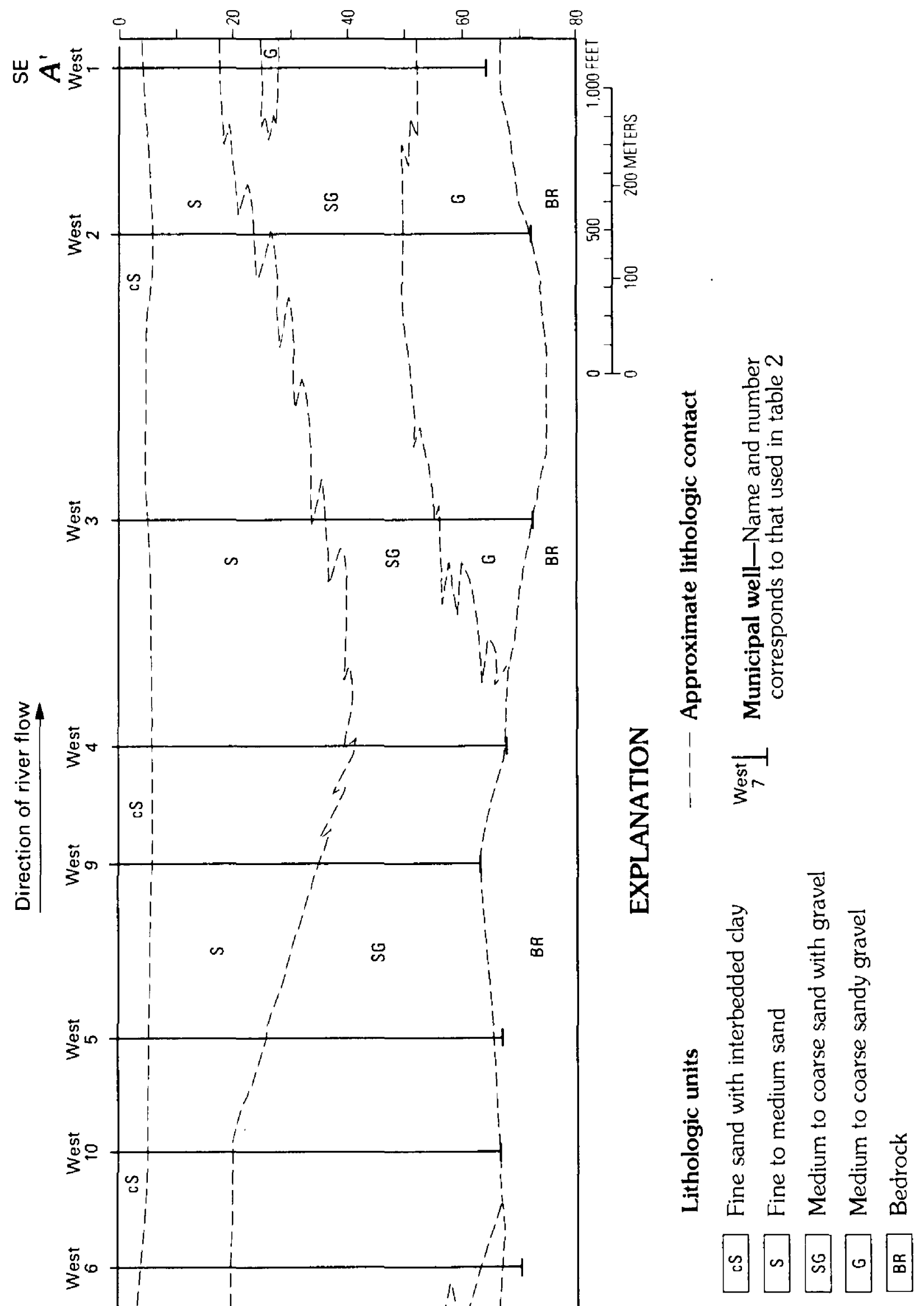

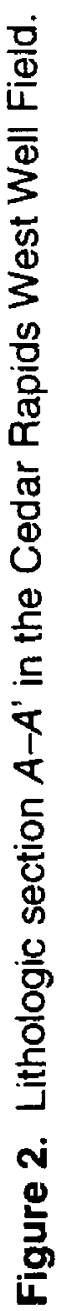




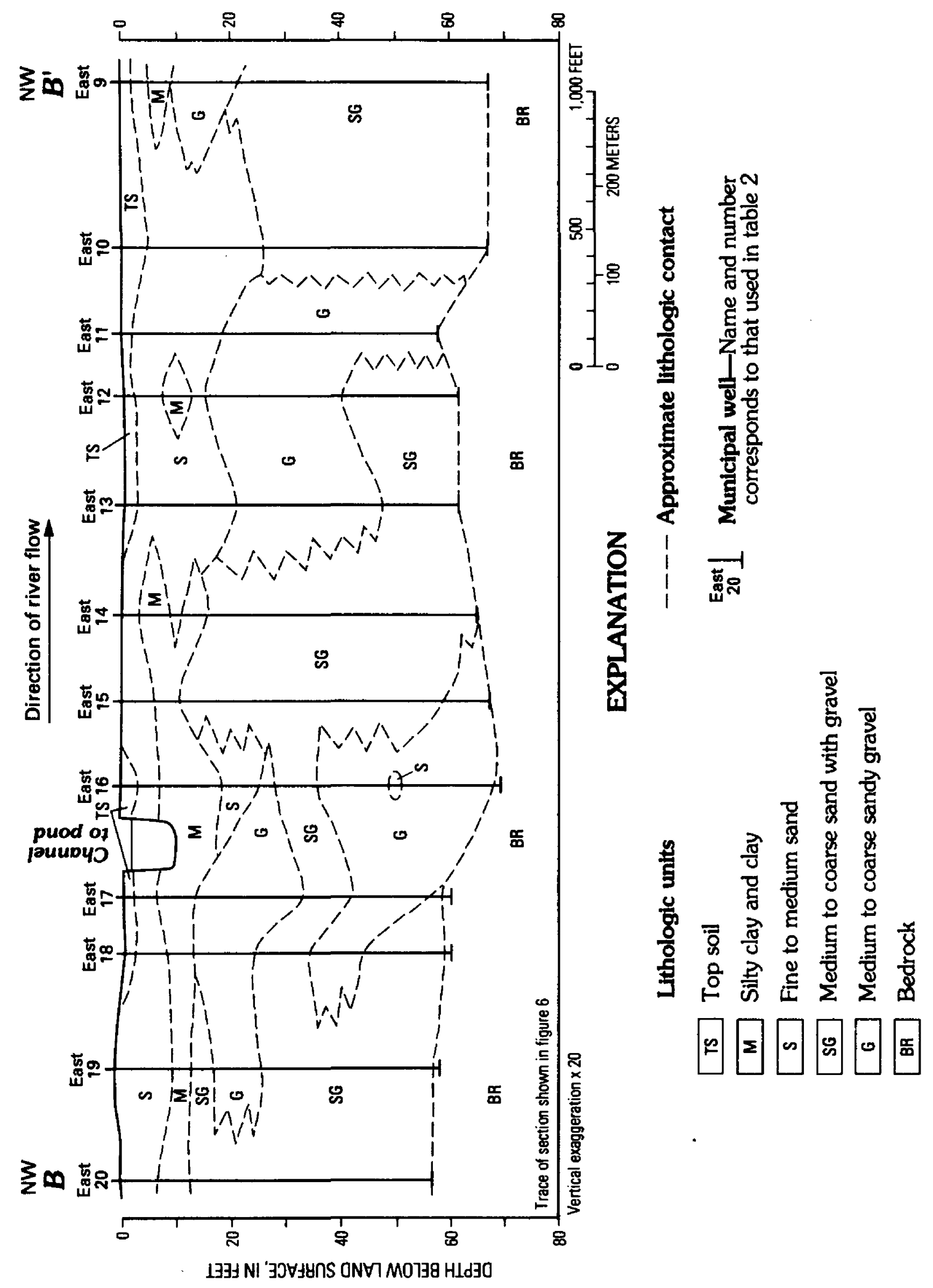

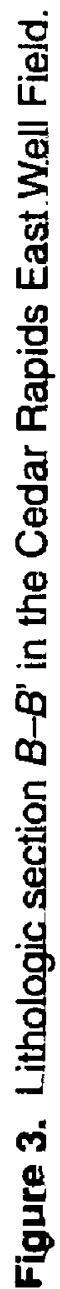



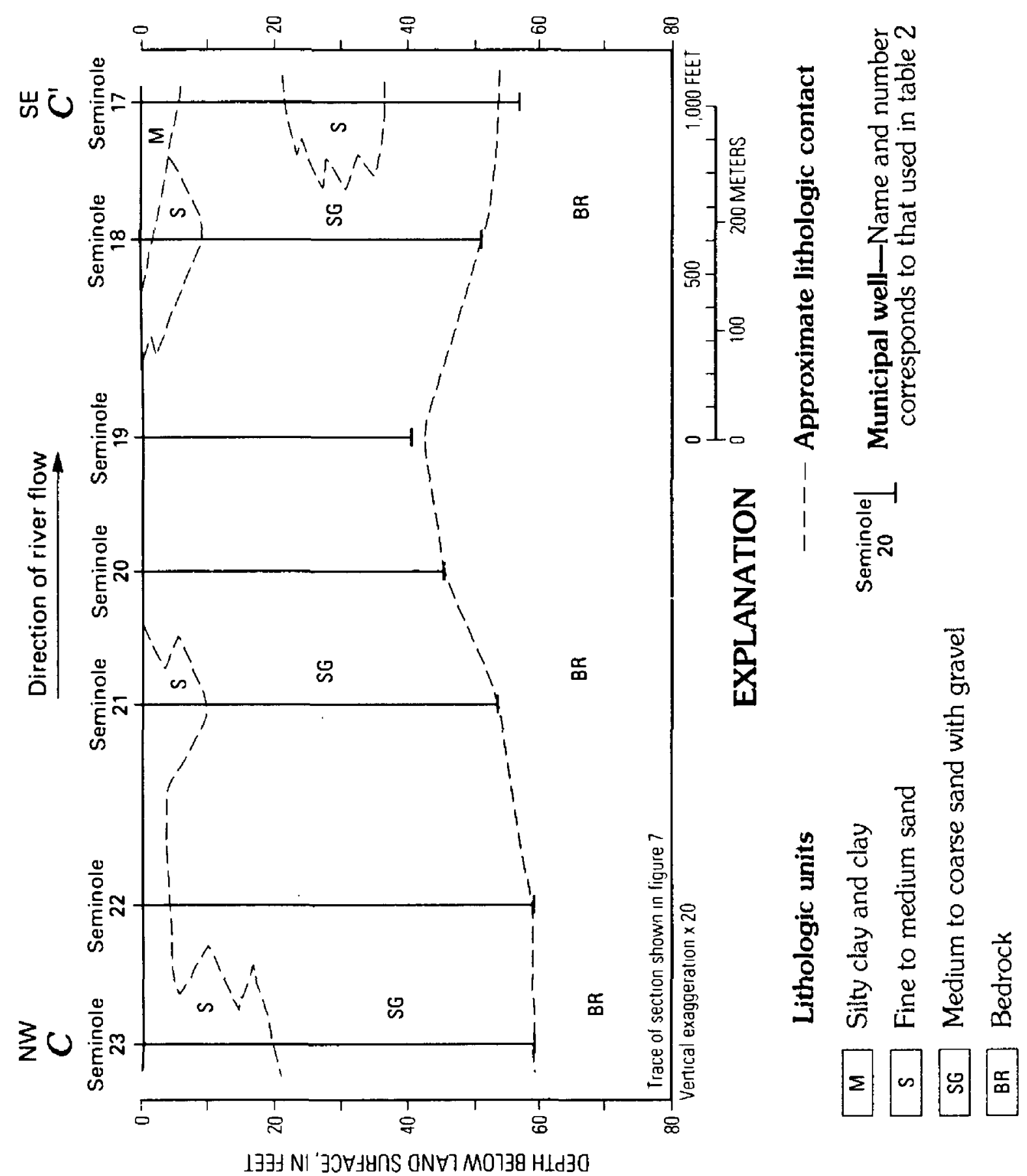

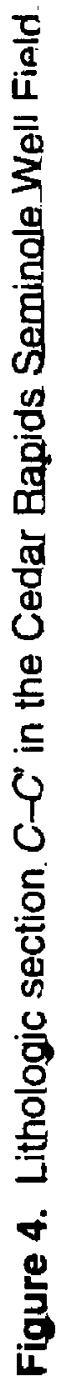



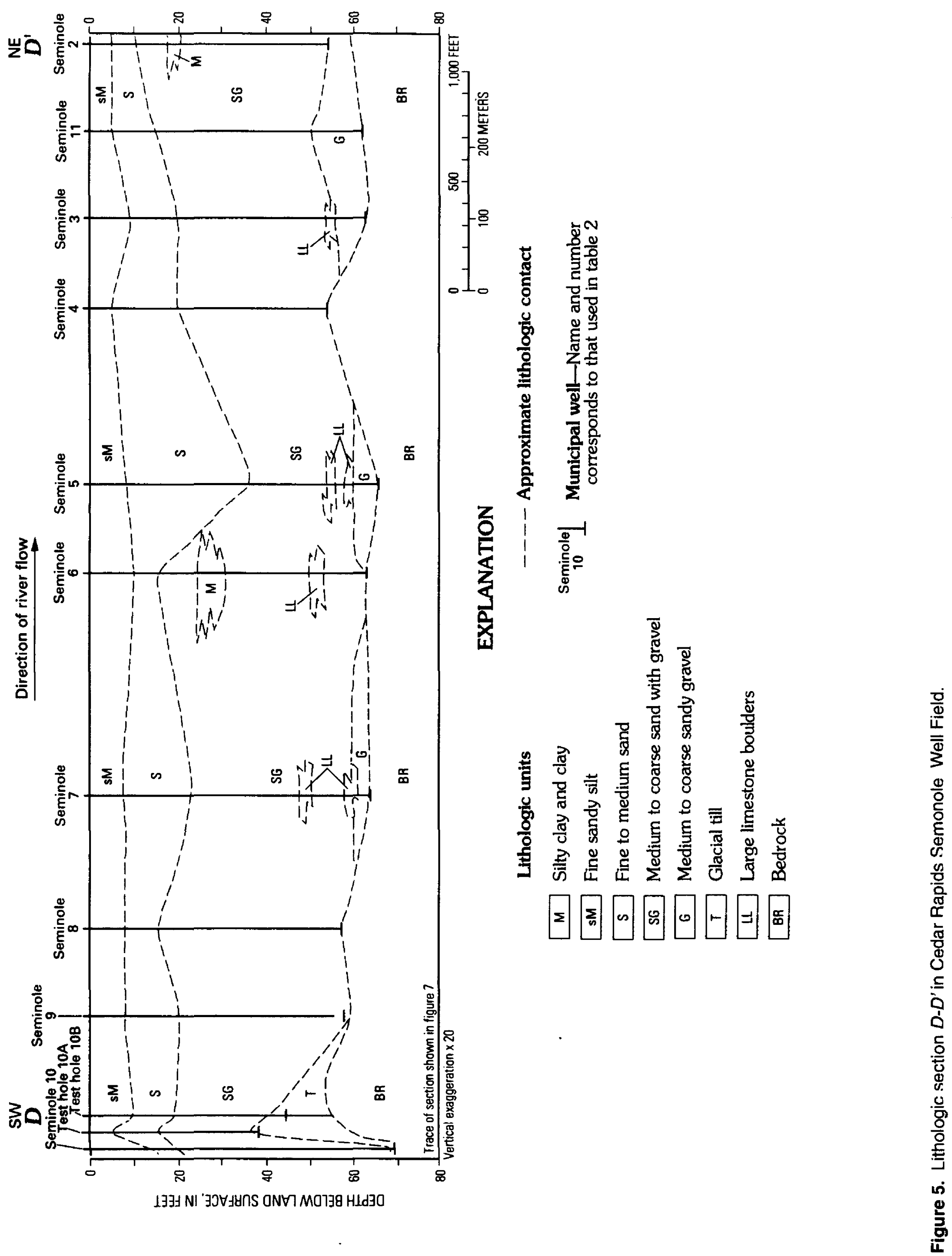
Table 1. Hydraulic properties for alluvial aquifer in which Cedar Rapids municipal wells are completed [(gal/min)/ft, gallons per minute per foot of drawdown; $\mathrm{ft}^{2} / \mathrm{d}$, foot squared per day; ft/d, foot per day; NR, no record]

\begin{tabular}{|c|c|c|c|c|c|c|c|}
\hline $\begin{array}{l}\text { Well name } \\
\text { and number } \\
\text { (figs. 6-7) }\end{array}$ & $\begin{array}{c}\text { Specific } \\
\text { capacity } \\
{[(\text { gal/min })} \\
/ f t]\end{array}$ & $\begin{array}{c}\text { Trans- } \\
\text { miss- } \\
\text { ivity } \\
\left(\text { ft }^{2} / \text { d) }\right.\end{array}$ & $\begin{array}{l}\text { Hydraulic } \\
\text { con- } \\
\text { ductivity } \\
\text { (ft/d) }\end{array}$ & $\begin{array}{c}\text { Well name and } \\
\text { number } \\
\text { (figs. 6-7) }\end{array}$ & $\begin{array}{c}\text { Specific } \\
\text { capacity } \\
{[(\text { gal/min })} \\
/ f t]\end{array}$ & $\begin{array}{c}\text { Trans- } \\
\text { miss- } \\
\text { ivlty } \\
\left(\mathrm{ft}^{2} / \mathrm{d}\right)\end{array}$ & $\begin{array}{l}\text { Hydraulic } \\
\text { con- } \\
\text { ductivity } \\
\text { (ft/d) }\end{array}$ \\
\hline East 1 & 21.1 & 2,706 & 38.7 & West 9 & 122.0 & 19,240 & 305.4 \\
\hline East 2 & 23.7 & 3,153 & 43.8 & West 10 & 63.6 & 9,354 & 139.6 \\
\hline East 3 & 42.9 & 6,156 & 85.5 & West 11 & 67.0 & 10,244 & 155.2 \\
\hline East 4 & 51.3 & 7,362 & 102.3 & Seminole 1 & 17.8 & 2,793 & 43.7 \\
\hline East 5 & 45.7 & 6,558 & 91.7 & Seminole 2 & 60.0 & 10,537 & 195.5 \\
\hline East 6 & 29.4 & 4,006 & 57.2 & Seminole 3 & 68.6 & 12,482 & 198.4 \\
\hline East 8 & 14.2 & 1,738 & 25.0 & Seminole 4 & 53.1 & 9,325 & 169.9 \\
\hline East 9 & 28.5 & 3,884 & 58.0 & Seminole 5 & 83.3 & 15,157 & 236.8 \\
\hline East 10 & 26.1 & 3,472 & 51.8 & Seminole 6 & 62.2 & 10,923 & 178.8 \\
\hline East 11 & 29.2 & 3,979 & 70.4 & Seminole 7 & 84.2 & 15,320 & 242.8 \\
\hline East 12 & 50.9 & 7,304 & 119.7 & Seminole 8 & 39.9 & 6,877 & 120.0 \\
\hline East 13 & 39.1 & 5,439 & 89.2 & Seminole 9 & 60.0 & 10,537 & 183.3 \\
\hline East 14 & 32.2 & 4,388 & 67.5 & Seminole 10 & 61.7 & 10,836 & 158.0 \\
\hline East 15 & 75.0 & 11,467 & 171.1 & Seminole 11 & 42.0 & 6,027 & 97.2 \\
\hline East 16 & 74.2 & 11,345 & 164.4 & Seminole 12 & 31.2 & 4,251 & 73.3 \\
\hline East 17 & 100.0 & 15,770 & 267.3 & Seminole 13 & 53.8 & 7,913 & 129.7 \\
\hline East 18 & 96.5 & 14,754 & 250.1 & Seminole 14 & 25.4 & 3,374 & 57.2 \\
\hline East 19 & 62.2 & 9,148 & 160.5 & Seminole 15 & 43.5 & 6,242 & 100.7 \\
\hline East 20 & 97.0 & 17,650 & 315.2 & Seminole 16 & 24.8 & 3,296 & 50.7 \\
\hline West 1 & 75.0 & 11,467 & 179.2 & Seminole 17 & 73.1 & 11,177 & 192.7 \\
\hline West 2 & 25.0 & 3,326 & 46.1 & Seminole 18 & NR & NR & NR \\
\hline West 3 & 12.6 & 1,543 & $21: 3$ & Seminole 19 & NR & NR & NR \\
\hline West 4 & 17.8 & 2,283 & 33.1 & Seminole 20 & NR & NR & NR \\
\hline West 5 & NR & NR & NR & Seminole 21 & NR & NR & NR \\
\hline West 6 & 39.5 & 5,597 & 78.9 & Seminole 22 & NR & NR & NR \\
\hline West 7 & 31.3 & 4,354 & 84.5 & Seminole 23 & NR & NR & NR \\
\hline West 8 & 24.1 & 3,206 & 51.9 & & & & \\
\hline
\end{tabular}


and East 20, these well are partially completed in a gravel lens of the alluvial aquifer (figs. 2, 3, and 5).

The Cedar River is the largest source of recharge available to the alluvial aquifer, and the rate of this recharge is dependent on the hydraulic conductivity of the aquifer, the hydraulic gradient between the river and the aquifer, and the infiltration capacity of the riverbed materials (Hansen, 1970). The withdrawal of water from a well constructed in the alluvial aquifer causes a depression of the water table surrounding the well called a "cone of depression." The withdrawal establishes a hydraulic gradient between the hydraulic head in the aquifer and the hydraulic head in the well, which causes water to flow from the surrounding aquifer towards the well. With large hydraulic conductivities and transmissivities (table 1), large volumes of water can move through the aquifer to the wells; for example, 37.1 Mgal/d was obtained on May 21, 1994, from the alluvial aquifer by the Cedar Rapids municipal wells (Bob Glass, City of Cedar Rapids Water Department, oral commun., 1994).

\section{Municipal Well Fields}

The City of Cedar Rapids has three well fields in operation along the Cedar River (figs. 1, 6, and 7). There are a total of 53 municipal wells (table 2), with 19 wells in the East Well Field, 11 in the West Well Field, and 23 in Seminole Well Field. Seminole wells 17 through 23 were not in use during the study. The well fields are located in the flood plain of the Cedar River, and the ground surface at some municipal well locations is inundated during river flood stage. The wells are installed in the alluvium at varying distances from the river (table 2) and drilled to the top of the bedrock. Well depths range from 40 to about $72 \mathrm{ft}$.

All municipal wells are of similar construction. A 42- or 52-in. diameter hole was drilled with a rotary auger. A 30-in. diameter casing was installed with a 10- to 20-ft stainless-steel screen that has 0.08 - to 0.10 -in. slots. Screens for all municipal wells are set close to or on top of the bedrock. Gravel was used to fill the annular space around the ssreen area. The remainder of the annular space was sealed with clay, such as bentonite, and cement from the top of the gravel to land surface. A berm was built-up around the well to cover the seal. Well-construction information is presented in table 2 .

\section{Intensive-Study Site}

The three well fields of the City of Cedar Rapids all have a similar lithologic sequence and hydraulic properties. This similarity in material and properties throughout the study area allowed the study to focus on one municipal well, Seminole 10 , and to assume that the hydrologic interpretations for this well are applicable to other municipal well locations. The intensive-study site is located northwest of Cedar Rapids at municipal well Seminole 10 and adjacent to the Cedar River (figs. 7 and 8). The aquifer in the vicinity of municipal well Seminole 10 has a transmissivity of $10,836 \mathrm{ft}^{2} / \mathrm{d}$ and a hydraulic conductivity of $158.0 \mathrm{ft} / \mathrm{d}$, which is representative of the well fields. The well is $48 \mathrm{ft}$ from the river, and its land-surface elevation is $725.4 \mathrm{ft}$ (table 2).

Sixty feet of 6-in. diameter pipe were laid in a trench extending from the top of the riverbank down into the river, near municipal well Seminole 10, to monitor changes in water level and selected waterquality properties and constituents in the Cedar River (fig. 8). The trench was filled and covered with rip-rap for protection. The end of the pipe was perforated to allow for the free flow of water.

Two, 4-in. diameter observation wells, CRM-3 and CRM-4, were installed to monitor changes in water levels and selected water-quality properties and constituents in the alluvial aquifer. Wells CRM-4 and CRM-3 were placed between Seminole 10 and the river and beyond Seminole 10, respectively (fig. 8). The observation wells were installed in the alluvial aquifer by the USGS using a hollow-stem auger. CRM-3 is located $58 \mathrm{ft}$ east, and well CRM-4 is located $22 \mathrm{ft}$ west of municipal well Seminole 10 (fig. 8). Another 4-in. diameter observation well, CRM-6 (fig. 8), was installed into the bedrock. Depths for the observation wells are listed in table 2 . The wells are constructed of schedule-80 polyvinyl chloride (PVC) pipe with a 2.5 -ft screened interval at the bottom. The annular space was filled by allowing the sides to collapse in around the well casing after placement of the screen and pipe. A seal of bentonite clay was placed at a depth of 6 to $7 \mathrm{ft}$ for wells CRM-3 and CRM-4 and at $80 \mathrm{ft}$ for well CRM-6. Seal thickness varied between observation wells. 

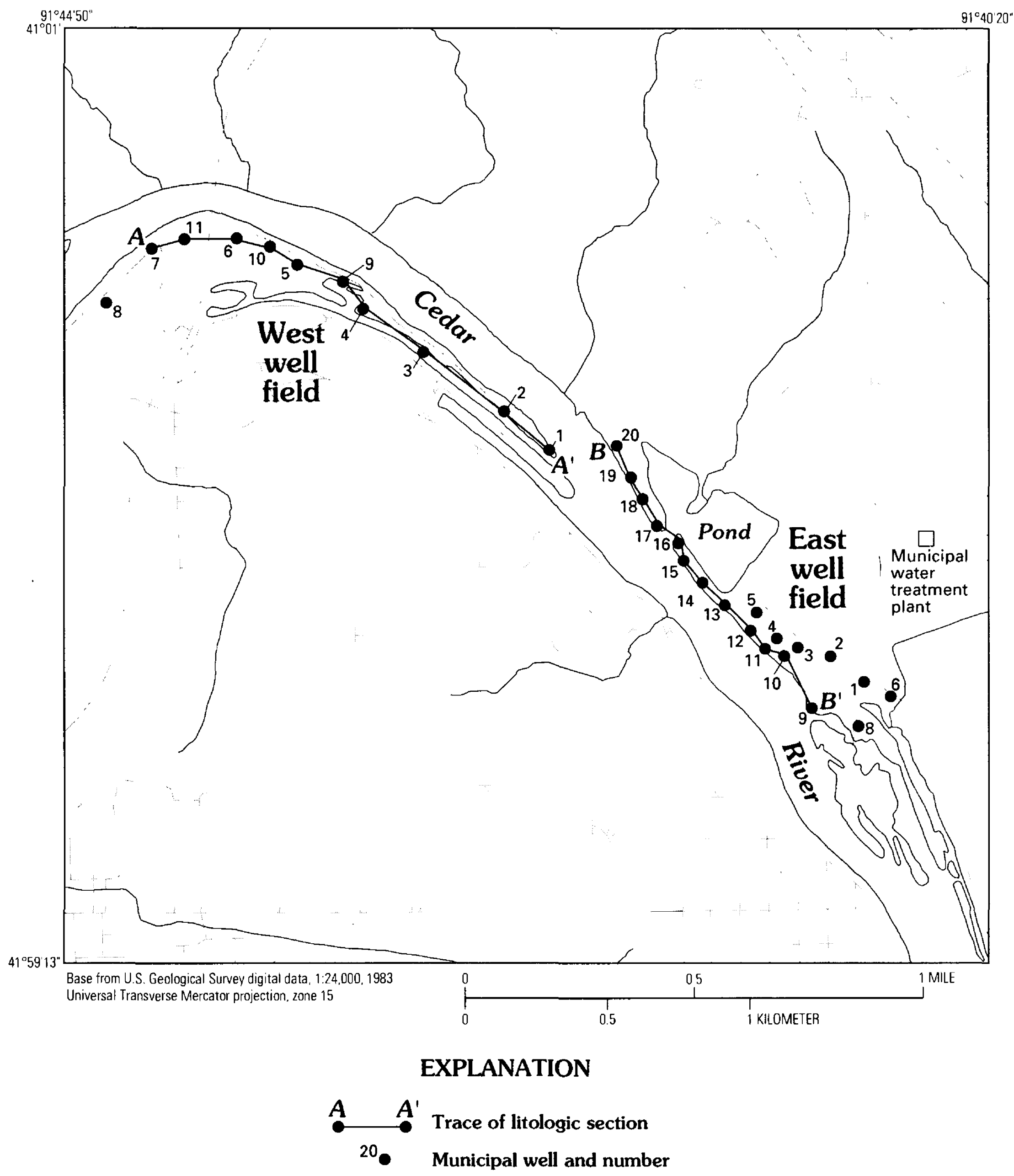

Figure 6. Location of municipal wells and traces of lithologic sections $A-A^{\prime}$ and $B-B^{\prime}$ in the Cedar Rapids East and West Well Fields. 


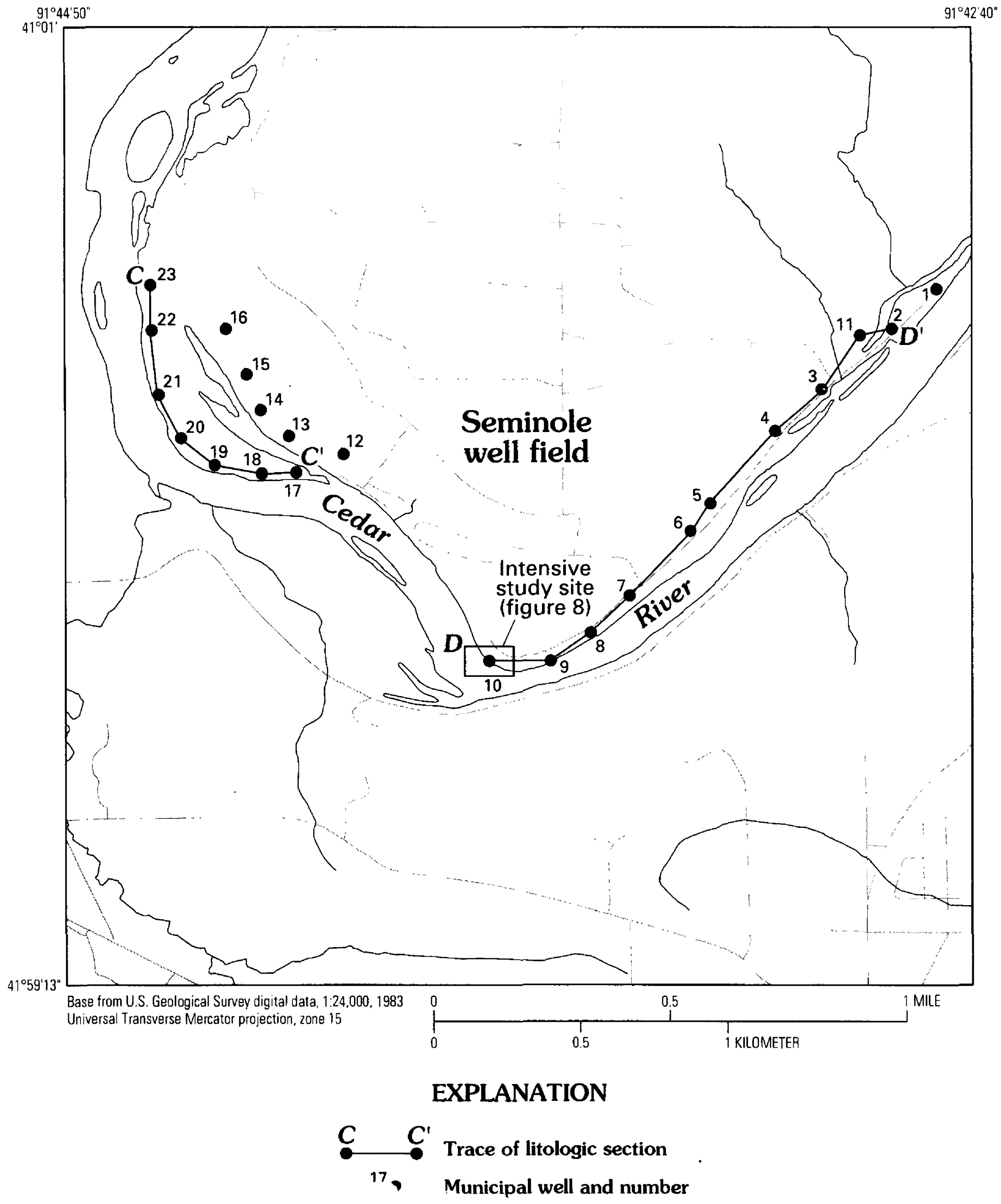

Figure 7. Location of municipal wells and traces of lithologic sections $C-C^{\prime}$ and $D-D^{\prime}$ in Cedar Rapids Seminole Well Field. 


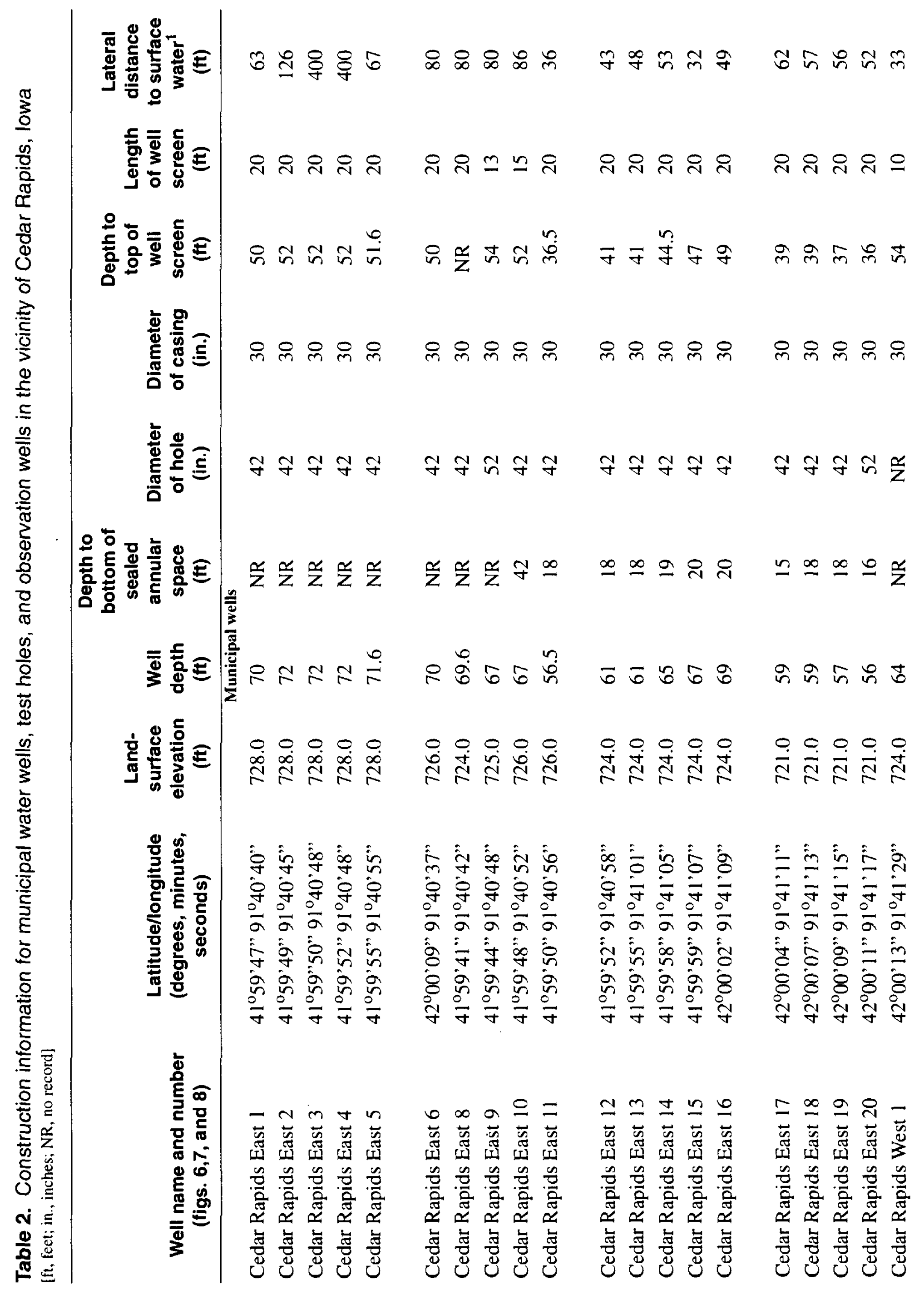




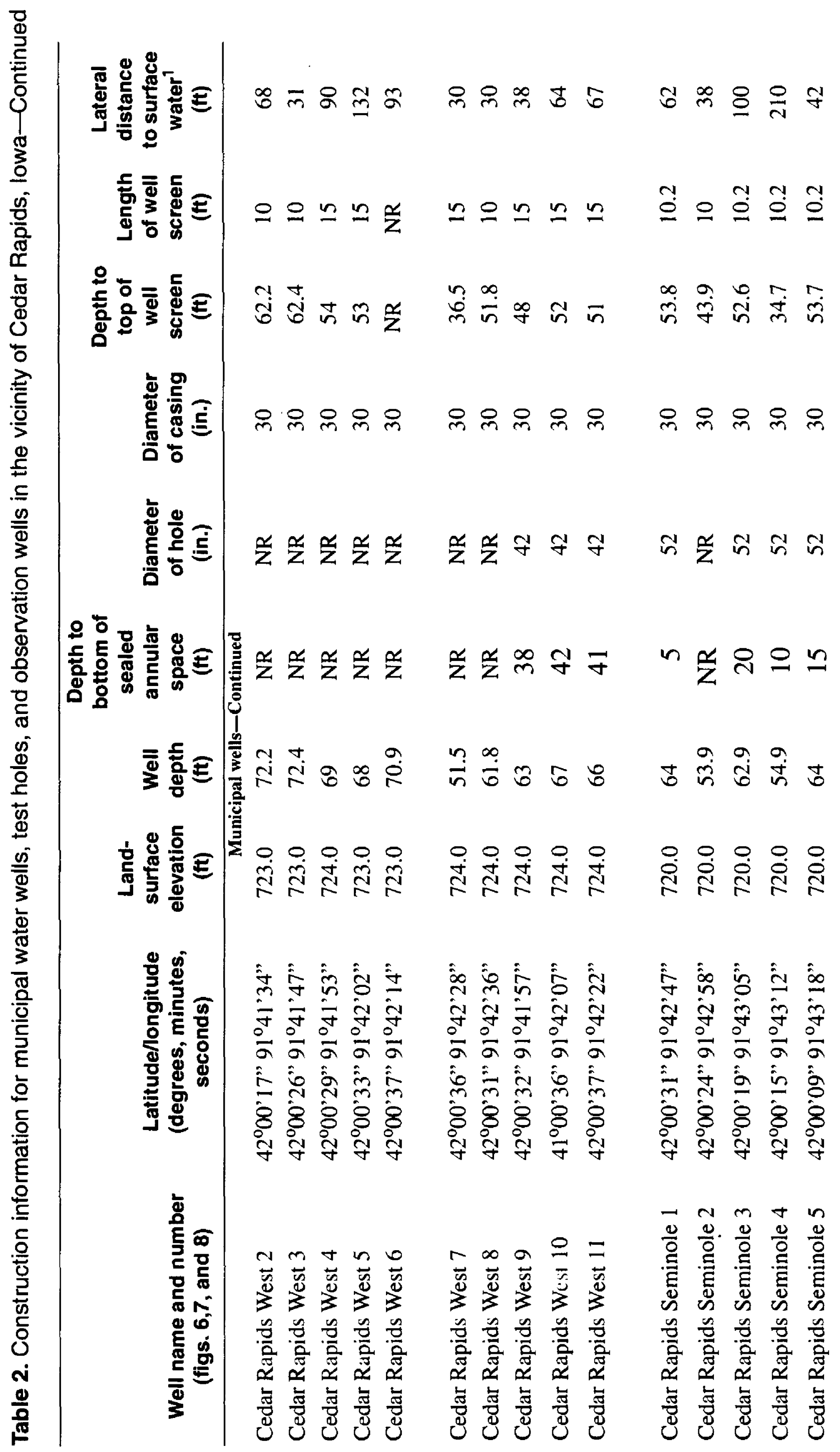




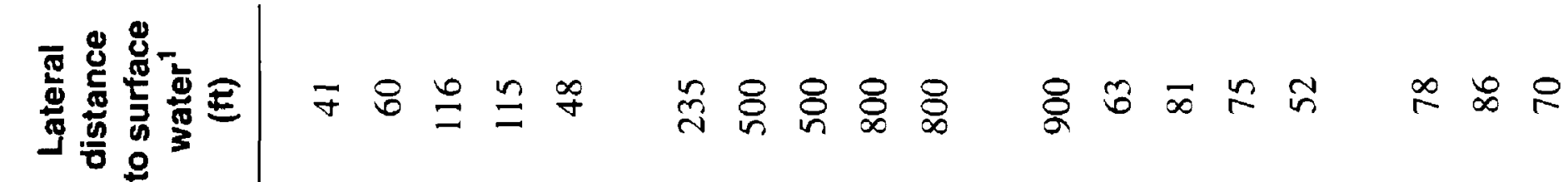

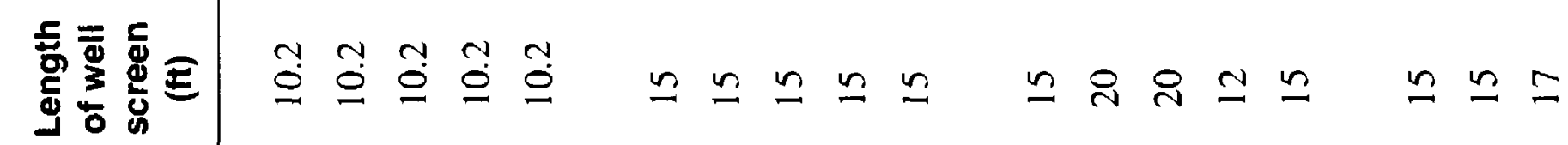

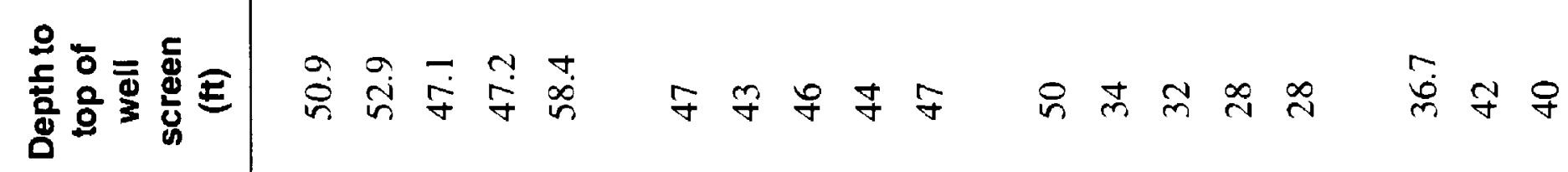

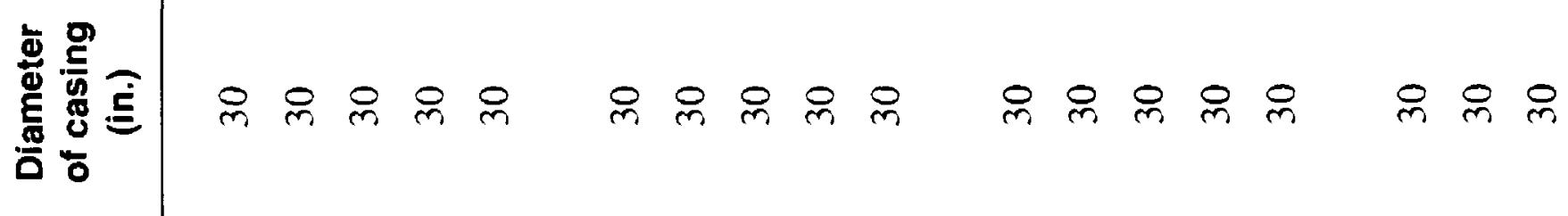

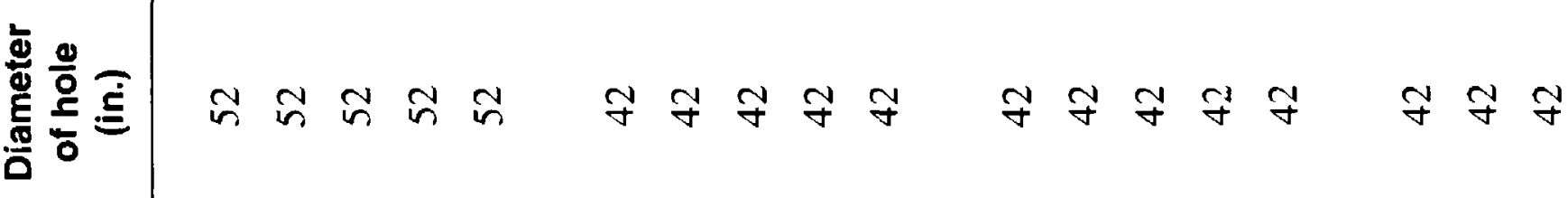

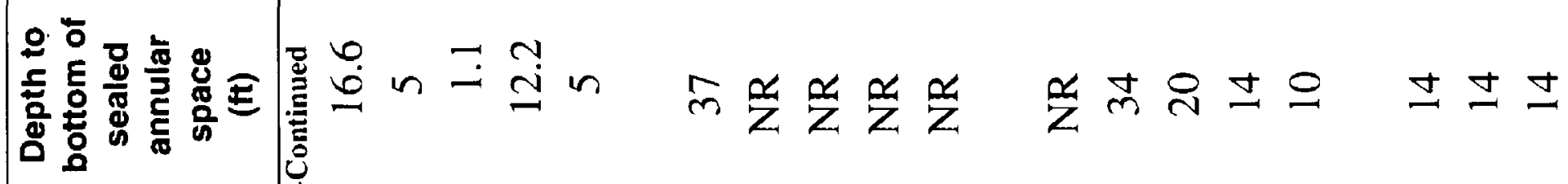

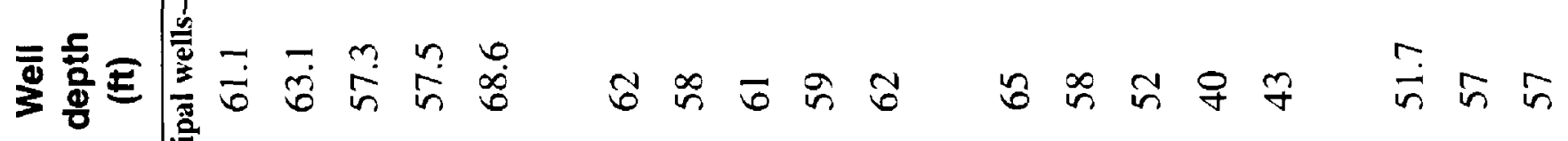

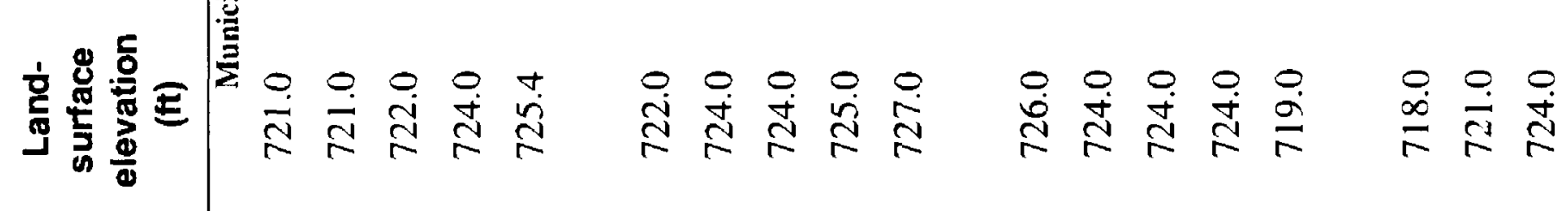

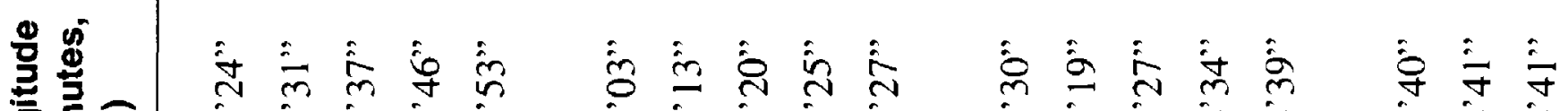

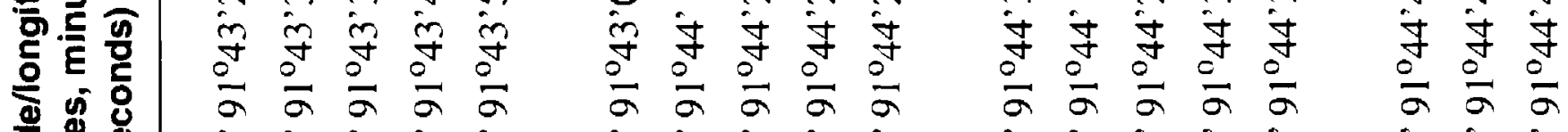

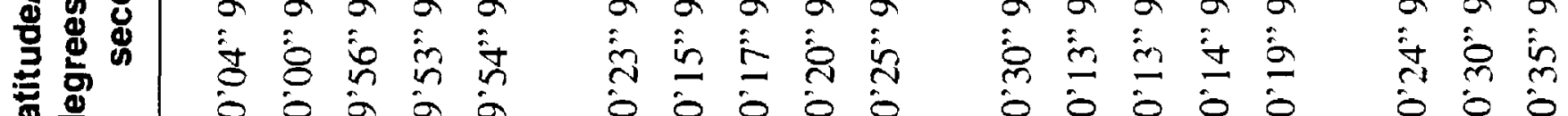
J 光光当

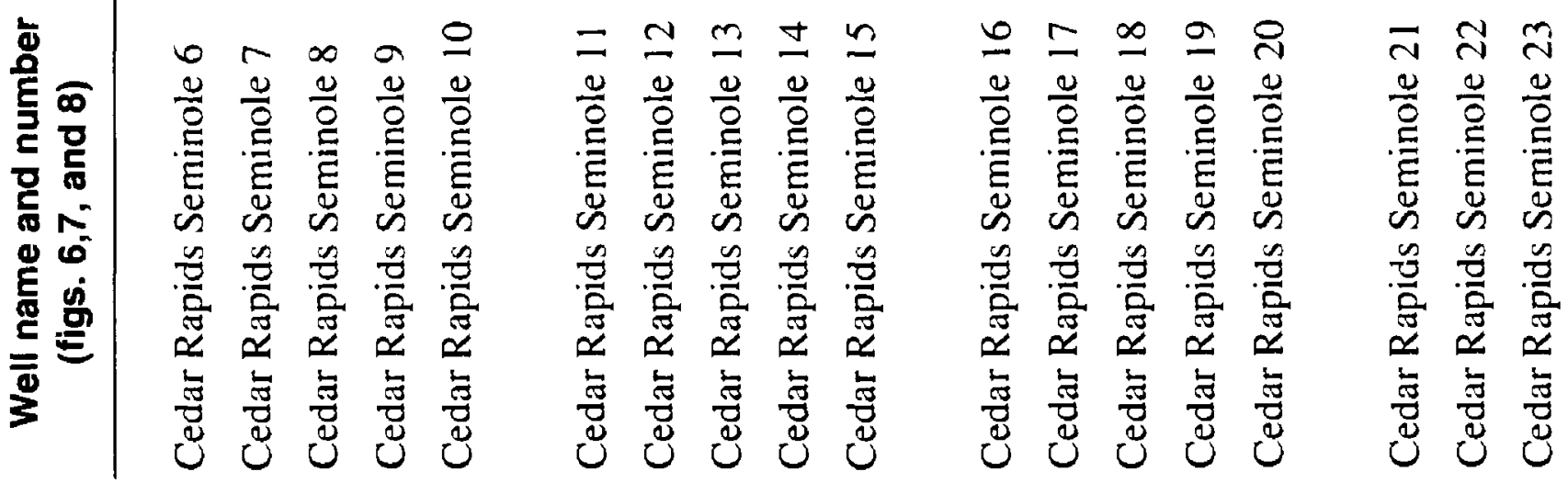




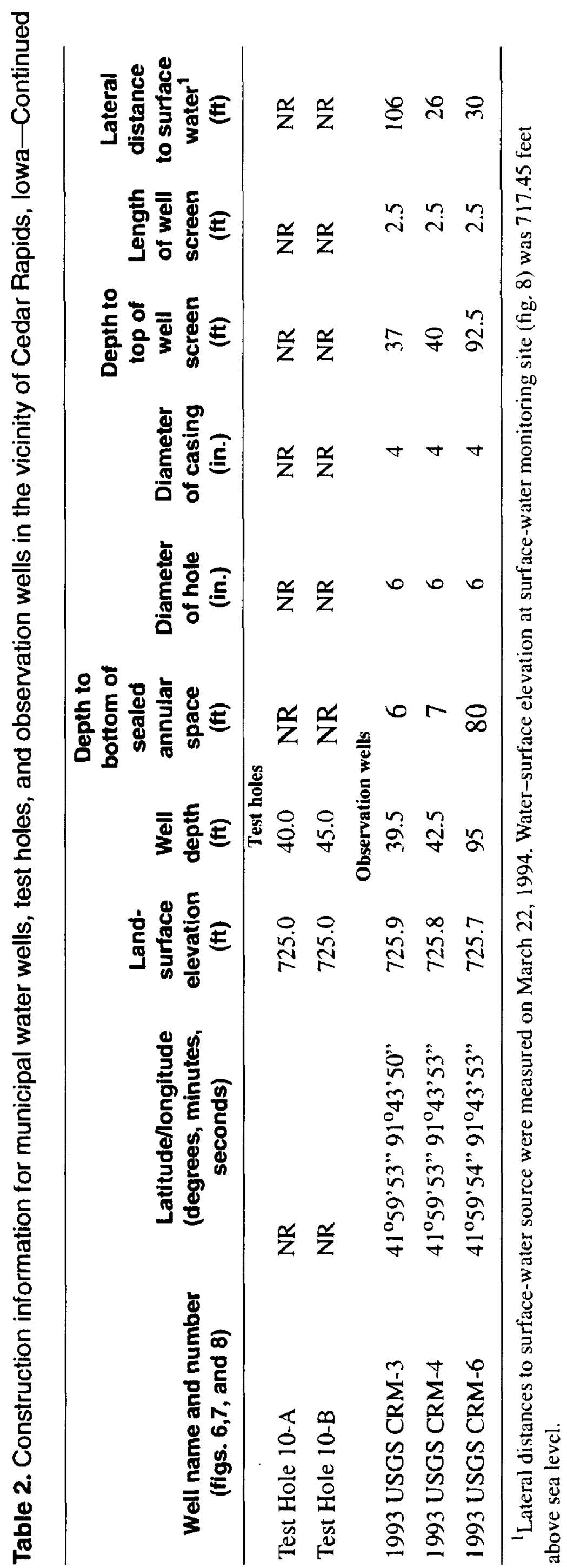




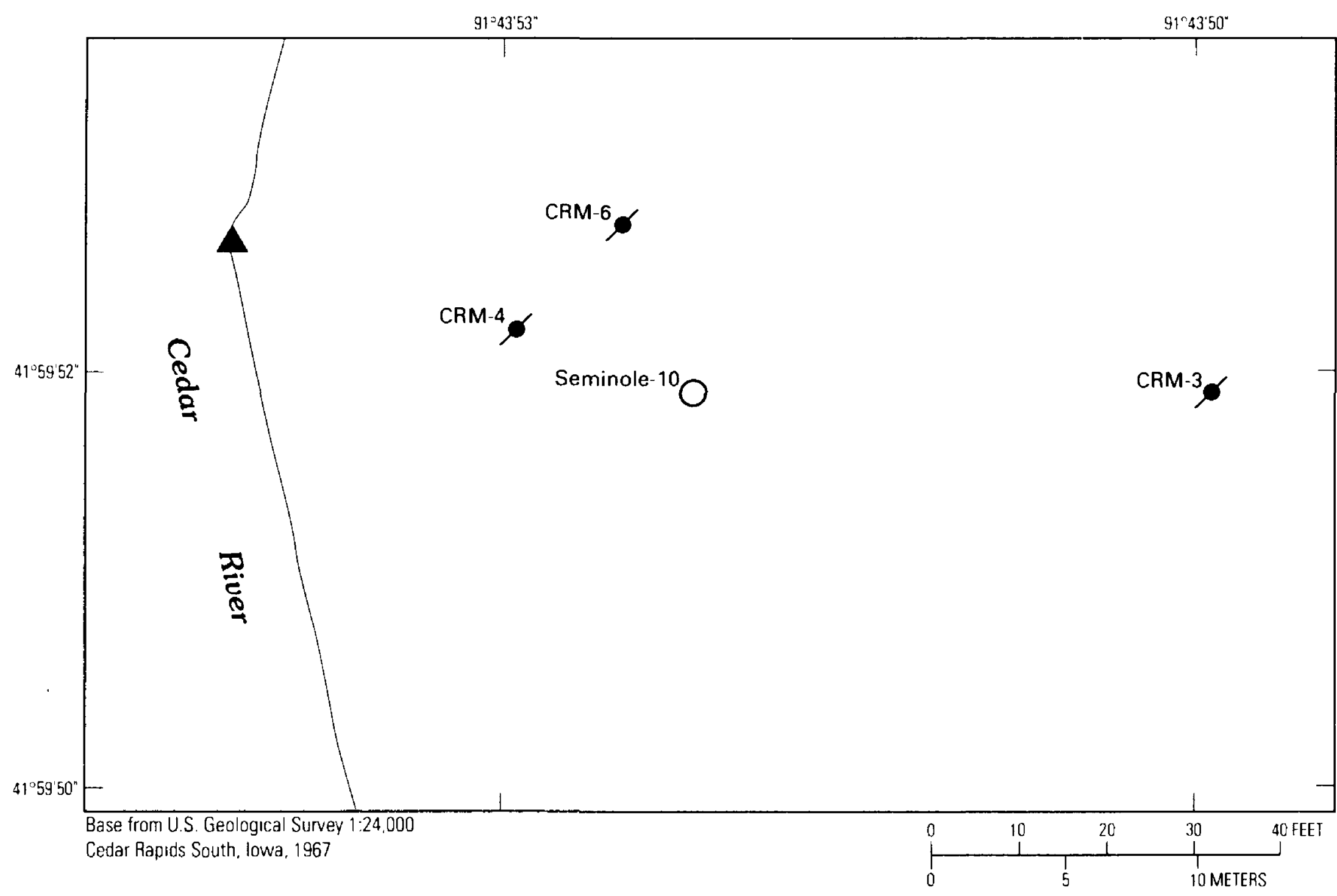

\section{EXPLANATION}

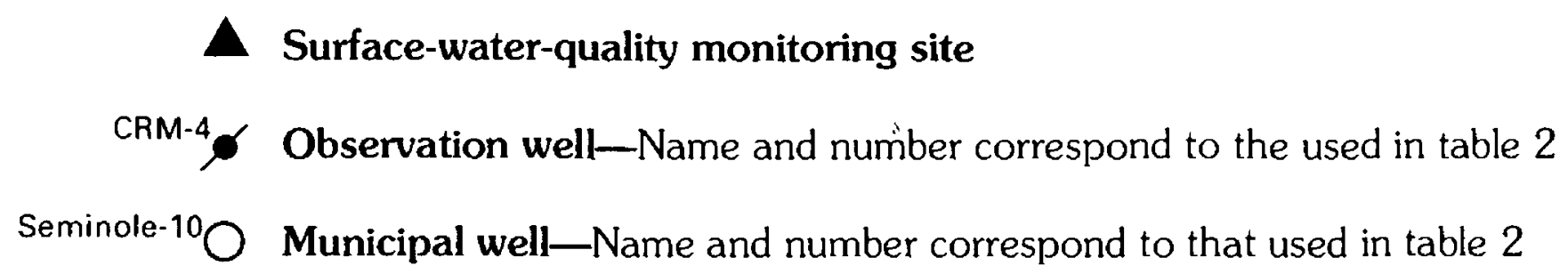

Figure 8. Intensive study site in vicinity of Cedar Rapids municipal well Seminole 10.

\section{DATA COLLECTION AND RESULTS}

A multiprobe instrument, Hydrolab DataSonde@3 , was used to continuously monitor water level, specific conductance, $\mathrm{pH}$, temperature, and dissolved oxygen in the Cedar River, observation

\footnotetext{
${ }^{1}$ Any use of product names is for descriptive purposes only and does not constitute endorsement by the U.S. Geological Survey.
}

wells CRM-3 and CRM-4, and municipal well Seminole 10 (fig. 8). The Cedar Rapids municipal watertreatment plant (fig. 6) also was monitored for the selected water-quality properties and constituents. The data were recorded at $15-, 30-$, or 60-minute intervals and are stored in the National Water Information System (NWIS) data base of the USGS. Selected water-quality properties and constituents, and surfacewater biogenic particulates were collected at the inten- 


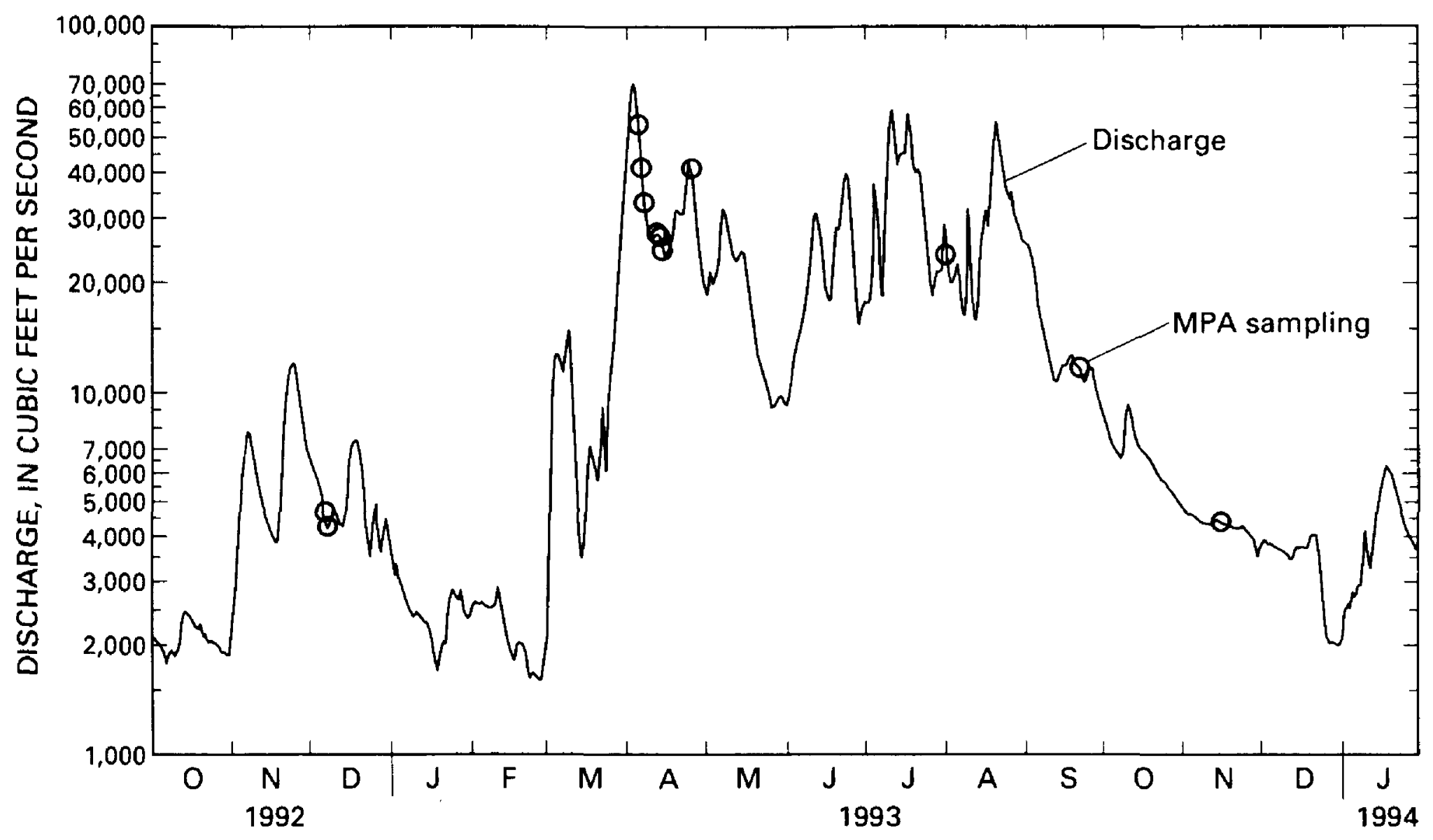

Figure 9. Daily mean discharge of the Cedar River at Cedar Rapids and collection dates of samples for microscopic particulate analysis (MPA), October 1992 through January 1994.

sive study site (figs. 7 and 8), while discharge measurements were collected about $5 \mathrm{mi}$ downstream from the intensive study site below the low-head dam (fig. 1).

The multiprobes in observation wells CRM-3 and CRM-4 were attached to a packer to isolate the instrument in the screened section of the well. Multiprobes were secured in the wells on a cable attached to the well caps. The multiprobe for the Cedar Rapids municipal water-treatment plant was placed just before the first step in the treatment process. Data from the multiprobes were retrieved every 2 weeks. During the winter months, retrieval of data from the river multiprobe was less frequent due to water freezing in the pipe. After data retrieval multiprobes were recalibrated and returned to the monitoring point. Specificconductance, $\mathrm{pH}$, and dissolved-oxygen values were adjusted automatically by the multiprobe for temperature.

\section{Cedar River Discharge and Stage}

Discharge of the Cedar River is systematically measured as part of the long-term, ongoing USGS data-collection program (Southard and others, 1994). Discharge measurements used in this study were made at the USGS gaging station at Cedar Rapids located 3,000 ft downstream of the low-head dam (fig. 1). The annual mean monthly flow for 1903 to 1993 at the USGS gaging station at Cedar Rapids is $3,658 \mathrm{ft}^{3} / \mathrm{s}$. The highest daily mean of $71,500 \mathrm{ft}^{3} / \mathrm{s}$ occurred on March 31, 1.961, and the lowest daily mean of $140 \mathrm{ft}^{3} / \mathrm{s}$ occurred on November 18, 1989 (Southard and others, 1994).

For the period of this study, December 1992 to January 1994, the highest daily mean discharge of $70,500 \mathrm{ft}^{3} / \mathrm{s}$ occurred on April 4, 1993; the lowest daily mean of $1,600 \mathrm{ft}^{3} / \mathrm{s}$ occurred on February 23 , 1993 , and the annual mean monthly flow was $15,130 \mathrm{ft}^{3} / \mathrm{s}$. A hydrograph (fig. 9) for the Cedar River 
at Cedar Rapids shows the mean daily discharge. Conditions during most of the study period were about 400 percent of normal for discharge and runoff. Annual runoff during the study was 31.55 in. compared to the mean annual runoff of 7.64 in. Due to the above-normal conditions the low-head dam had little effect on the flow of the river, which normally withholds and releases water to generate power during peak hours.

Stage of the Cedar River was measured by the multiprobe at the intensive-study site. Stage data are shown in figure 10 . Records show that the ground surface at municipal well Seminole 10 was inundated four times by the Cedar River in 1993 - once in April, twice in July, and once in August.

\section{Ground-Water Levels}

The multiprobes in observation wells CRM-3 and CRM-4 were fitted with strain gages to measure water levels within a range of $0-33 \mathrm{ft}$ with a precision of $0.15 \mathrm{ft}$. The multiprobe used in municipal well Seminole 10 was fitted with a strain gage to measure water levels within a range of $0-328 \mathrm{ft}$ with a precision of $1.48 \mathrm{ft}$ (Hydrolab Corporation, 1991). The waterlevel sensor automatically compensated for water density. Periodically, manual water-level measurements were made with a steel tape and were recorded to within $0.01 \mathrm{ft}$ to verify the multiprobe measurements.

Mean daily water levels for observation wells CRM-3 and CRM-4 and municipal well Seminole 10 are listed in tables 8 through 11 at the end of this report and are graphically compared to stage of the Cedar River in figure 10 . The majority of missing water-level data for well CRM-4 resulted from water levels exceeding the tolerance of the sensor. Results of periodic manual measurements in wells CRM-3, CRM-4, and CRM-6 are listed in table 12 at the end of this report.

Water levels for wells CRM-3 and CRM-4 closely follow the stage of the river. During pumping, municipal well Seminole 10 drawdown causes the water level to range from 12 to $20 \mathrm{ft}$ below river stage, which results in a steep gradient between the Cedar River and well Seminole 10. The direction of groundwater flow is toward the well. When the well was not pumping, water levels in wells CRM-3, CRM-4, and Seminole 10 were similar to the level of the river.

Generally the direction of ground-water flow was from the river to the alluvial aquifer as a result of drawdown from pumping. Water levels measured February 1 through 9, 1993, show that the direction of ground-water flow was from the alluvial aquifer to the river. During this period, municipal well Seminole 10 was not pumping.

On November 4 and December 20, 1993, comarative water levels for observation wells CRM-3, CRM-4, and CRM-6 indicate that ground-water flow from the bedrock aquifer was upward toward the alluvial aquifer. The upward gradient indicates that the bedrock is a source of recharge to the alluvial aquifer at this location.

\section{Selected In-Situ Water-Quality Properties and Constituents}

\section{Specific Conductance}

The mean daily specific-conductance values for water in the Cedar River ranged from a maximum value of $640 \mu \mathrm{S} / \mathrm{cm}$ (microsiemens per centimeter at $25^{\circ} \mathrm{C}$ ) on February 1, 1993, to a minimum value of $223 \mu \mathrm{S} / \mathrm{cm}$ on March 5, 1993. Maximum and minimum values for mean daily specific conductance for observation well CRM-4 and municipal well Seminole 10 are similar in range and time period to those of the river. Observation well CRM-4 had a maximum value of $658 \mu \mathrm{S} / \mathrm{cm}$ on February 25, 1993, and the minimum value of $272 \mu \mathrm{S} / \mathrm{cm}$ on March 10 , 1993. Municipal well Seminole 10 had a maximum values of $640 \mu \mathrm{S} / \mathrm{cm}$ on January 11 and 12, 1994; $635 \mu \mathrm{S} / \mathrm{cm}$ on February 15, 1993; and $636 \mu \mathrm{S} / \mathrm{cm}$ on March 3, 1993. The minimum value for well Seminole 10 was $287 \mu \mathrm{S} / \mathrm{cm}$ on April 10, 1993. Values of mean daily specific conductance for observation well CRM-3 and the municipal water-treatment plant were less similar to values in the river. The maximum was $655 \mu \mathrm{S} / \mathrm{cm}$ on February 17, 1993, and the minimum was $426 \mu \mathrm{S} / \mathrm{cm}$ on May 14, 1993, for observation well CRM-3. The maximum specific-conductance value for the municipal water-treatment plant was $602 \mu \mathrm{S} / \mathrm{cm}$ on March 2, 1993, and the minimum value was $418 \mu \mathrm{S} / \mathrm{cm}$ on August 20, 1993. Mean daily specific conductance values are tabulated at the end of this report in tables 13 through 17.

\section{pH}

The data show no significant or rapid changes in $\mathrm{pH}$ for water from wells and the municipal watertreatment plant compared to that from the Cedar River. 


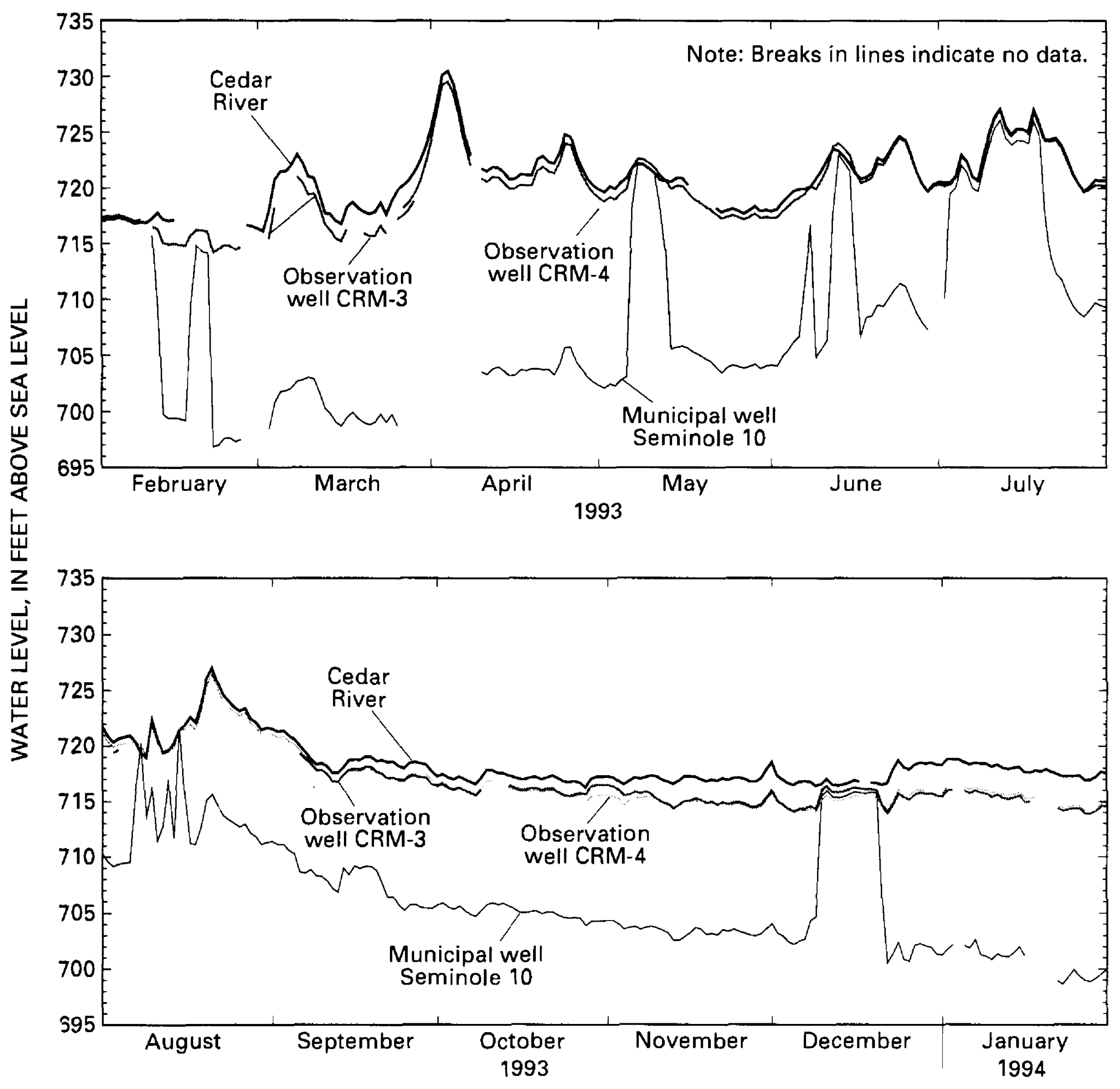

Figure 10. Water levels in the Cedar River, Cedar Rapids municipal well Seminole 10, and observation wells CRM-3 and CRM-4, February 1, 1993, through January 31, 1994.

The $\mathrm{pH}$ data are tabulated in tables 18 through 22 at the end of this report. The daily mean $\mathrm{pH}$ values for the river water ranged from a minimum of 7.3 in March 1993 to a maximum of 8.5 in May and June of 1993. Values for observation well CRM-4 were similar in range from 7.4 to 8.2 and for municipal well Seminole 10 from 7.2 to 8.0 . pH. Values of $\mathrm{pH}$ for water from observation well CRM-3 and the municipal water-treatment plant were smaller, ranging from 6.9 to 7.5 and 6.3 to 7.5 , respectively.

\section{Temperature}

Maximum mean daily river temperature was $24.6{ }^{\circ} \mathrm{C}$ on August 27,1993 , and a minimum mean daily temperature of $-0.1^{\circ} \mathrm{C}$ was recorded from February 1 through March 6, 1993, and from December 23, 1993, through January 25, 1994. Maximum and minimum mean daily values for observation well CRM-4 were $24.5^{\circ} \mathrm{C}$ on September 3, 1993, and $0.1{ }^{\circ} \mathrm{C}$ from February 14 through March 14, 1993 and from December 31, 1993, through January 31, 1994. Maximum and minimum 
mean daily values for municipal well Seminole 10 were $21.4^{\circ} \mathrm{C}$ on September 13, 1993, and $-0.2{ }^{\circ} \mathrm{C}$ from February 5-16, 1993, and on January 23, 24, and 26-29, 1994. Maximum and minimum mean daily values for observation well CRM-3 were $18.7^{\circ} \mathrm{C}$ on December 2, 1993, and $0.6^{\circ} \mathrm{C}$ from February $10-13$, 1993. Maximum and minimum mean daily values for the municipal water-treatment plant were $17.6^{\circ} \mathrm{C}$ on September 13, 1993, and $5.9{ }^{\circ} \mathrm{C}$ on April 10, 1993. Mean daily temperature values are tabulated at the end of this report in tables 23 through 27.

The water temperatures for observation well CRM-4 seem to follow the trend of water temperatures in the Cedar River. Water temperatures for municipal well Seminole 10 also follow the trend of water temperatures in the river but not as closely as those for observation well CRM-4. Water temperatures for observation well CRM-3 and the municipal watertreatment plant do not follow the variations in water temperatures for the river as the temperature in the river increases and decreases throughout the year.

\section{Dissoived Oxygen}

The Cedar River had a maximum concentration of dissolved oxygen of $15.2 \mathrm{mg} / \mathrm{L}$ on February 3 , 1993 , and a minimum concentration of $6.0 \mathrm{mg} / \mathrm{L}$ on August 20, 1993. Maximum and minimum concentrations for observation well CRM-4 were $12.3 \mathrm{mg} / \mathrm{L}$ on December 28, 1993, and $0.1 \mathrm{mg} / \mathrm{L}$ on September 2, 1993. Maximum and minimum concentrations for municipal well Seminole 10 were $11.5 \mathrm{mg} / \mathrm{L}$ on January 2, 1994, and $0.4 \mathrm{mg} / \mathrm{L}$ from February 1-3, February 10, August 1-5 and 17-23, and September 11-13 and 15-18, 1993. Maximum and minimum concentrations for observation well CRM-3 were $3.1 \mathrm{mg} / \mathrm{L}$ on February 10,1993 , and $0.2 \mathrm{mg} / \mathrm{L}$ from February 14-16, November 10, 25, 26, and 28, December 3-5, 1993, and on January 31, 1994. Maximum and minimum concentrations for the municipal water-treatment plant were $11.2 \mathrm{mg} / \mathrm{L}$ on July 17 , 1993, and $0.4 \mathrm{mg} / \mathrm{L}$ on February 25, 1993. Mean daily concentration values of dissolved oxygen are tabulated at the end of this report in tables 28 through 32 .

Concentrations of dissolved oxygen in the river tend to be higher than the dissolved-oxygen concentrations in water from observation well CRM-4, municipal well Seminole 10, observation well CRM-3, and the water-treatment plant. The trend of dissolvedoxygen concentration in well CRM-4 is similar to the concentrations in the river but in smaller quantities.
Concentrations in well Seminole 10 are similar to concentrations in well CRM-4 except during May through September. Dissolved-oxygen concentrations in well CRM-3 were fairly stable throughout the study period.

\section{Microscopic Particulate Analysis}

Microscopic particulate data were collected using the method outlined by the U.S. Environmental Protection Agency (USEPA) to determine if a groundwater source is GWUDI according to the SWTR (Vasconcelos and Harris, 1992). Prior to sampling, municipal wells were pumped for a minium of 1 week to assure sufficient time for aquifer conditions to stabilize. Samples were collected from the Cedar River, municipal wells East 1 and 19, West 6, and Seminole $2,3,10,14$, and 16 , and the Cedar Rapids municipal water-treatment plant during April 1993, a period of above-normal flow. Additional samples for the river and Seminole wells 10,14 , and 16 were collected throughout the study period. Samples collected during a period of high flow, when several wells were inundated, are important because the alluvial aquifer could be at a higher risk of contamination by surface water during this period. Samples were collected by USGS personnel and sent to the laboratory of Analytical Services, Inc., in Essex Junction, Vermont, for MPA.

Analysis of 29 samples found no Giardia cysts or Crytosporidium oocysts in water collected from municipal wells and the municipal water-treatment plant (table 3). A total of five Giardia cysts and four Crytosporidium oocysts were detected in the Cedar River samples, some with and some without internal structure.

Chlorophyll-containing algae (table 3 ) were detected in all but one of the wells sampled. The algae counts in the selected wells generally were insignificant compared to the algae counts in the river water. The largest counts occurred during flooding in April 1993. Counts of algae found in samples from the municipal water-treatment plant and municipal wells Seminole 3,14 , and 16 ranged from $1.9 \times 10^{3}$ to $7.9 \times 10^{4}$ per 100 gal of water during this time, three orders of magnitude higher than normally found. In comparison, the river samples contained algae counts of $1.6 \times 10^{7}$ to $3.8 \times 10^{7}$ per 100 gal of water, whereas samples from municipal wells East 1 and 9, West 6, and Seminole 2 and 10 contained counts ranging from 1 to 16 per 100 gal. 


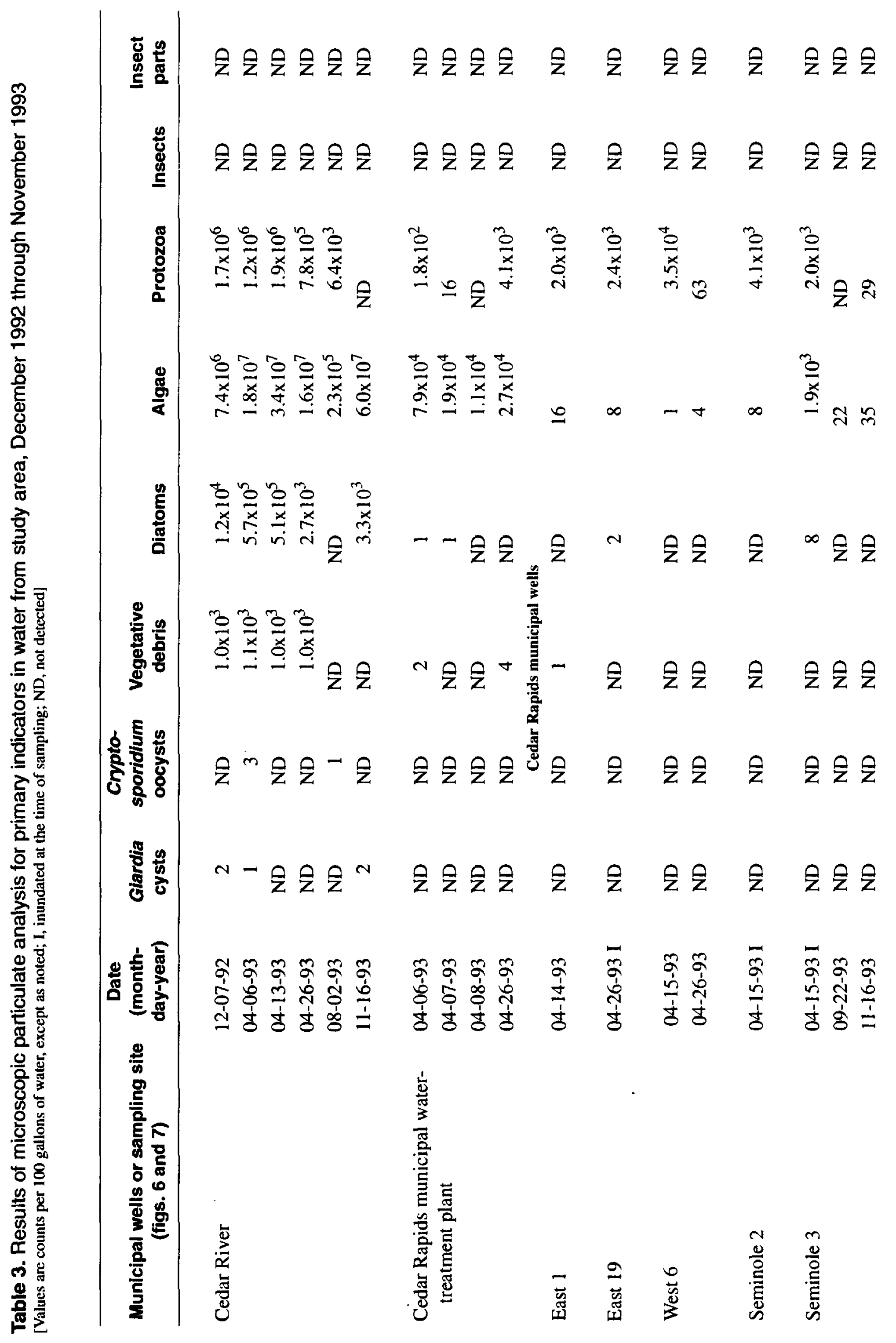




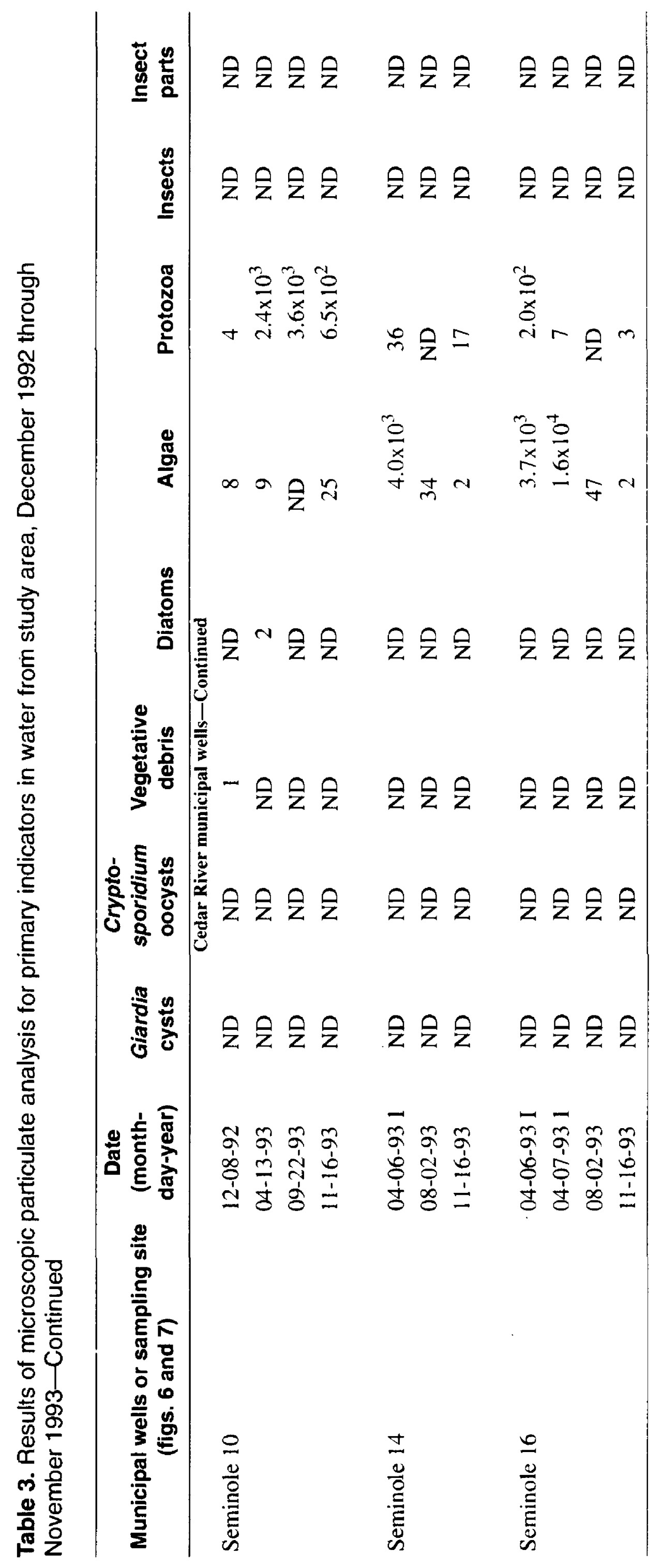


Diatoms (table 3) were found only in samples from three wells and the municipal water-treatment plant during the period of flooding. The counts ranged from 1 to 8 compared to counts ranging from $2.7 \times 10^{3}$ to $5.7 \times 10^{7}$ per $100 \mathrm{gal}$ in the river samples throughout the period of sampling. The count of rotifers found in the wells also was small compared to those found in the river samples (table 4). Some free-living rotifers have highly specialized food habits not associated with surface water if sufficient organic debris, fungi, and bacteria are present as a food supply (Vasconcelos and Harris, 1992). Vegetative debris (table 4), spores, pollen, crustaceans, crustacean eggs, nematodes, nematode eggs, amoebae, and invertebrate eggs (table 5) all showed very small counts in the well samples compared to the larger counts in the river samples. No insects or insect parts were found in any of the samples collected (table 4). Results for volume of sample filtered, turbidity, filter color, $\mathrm{pH}$ of sample, and amorphous debris are presented in table 5. Turbidity of water from the wells sampled is generally less than the turbidity of the river except where wells have a high occurrence of iron bacteria.

\section{EFFECT OF THE CEDAR RIVER ON SELECTED WATER-QUALITY PROPERTIES AND CONSTITUENTS OF THE ALLUVIAL AQUIFER}

Variations in the specific conductance, $\mathrm{pH}$, temperature, and dissolved-oxygen concentrations of water in the alluvial aquifer can be related to the Cedar River. Before addressing these relations, some aspects of water-quality variations in the Cedar River and traveltimes of water in the alluvial aquifer are discussed.

Specific conductance, $\mathrm{pH}$, and the concentration of dissolved oxygen change inversely with changes in river stage or discharge (Schulmeyer, 1991). Increases in discharge of the Cedar River resulting from runoff had an inverse effect on the values of specific conductance, $\mathrm{p}^{-\mathrm{H}}$, and concentration of dissolved uxygen in the river as a result of dilution (figs. 11, 12, and 13). Precipitation, resulting in overland flow generally has a smaller specific condurtance and $\mathrm{pH}$, ranging from 5 to $74 \mu \mathrm{S} / \mathrm{cm}$ and 4.0 to $7.3 \mathrm{pH}$ (Southhard and others, 1994), respectively, compared to the specific conductance and $\mathrm{pH}$ of ground water in alluvial and bedrock aquifers, which ranges from 390 to $1,800 \mu \mathrm{S} / \mathrm{cm}$ and 6.8 to $8.0 \mathrm{pH}$ (Wahl and Bunker, 1986). Because the Cedar River can receive a major part of its flow from ground-water contribution, especially during periods of below-normal precipitation, the specific-conductance, $\mathrm{pH}$, and dissolvedoxygen values of river water can be similar to values measured in the ground water. When runoff occurs dilution takes place. With a large amount of runoff, substantial decreases in values of specific conductance, $\mathrm{pH}$, and dissolved oxygen for water from the Cedar River can take place. Subsequently, these changes can be seen in the alluvial aquifer as water from the river moves toward municipal well Seminole 10 over a period of time.

Water-quality properties and constituents of water pumped from the alluvial aquifer change as water flows from the Cedar River to municipal well Seminole 10 as a result of drawdown. The amount of time needed for water to travel through the aquifer could be an indication of the susceptibility of the alluvial aquifer to surface-water effects. Giardia cysts have a period of viability dependent on length of time in the environment and temperature (Wilson and others, 1992). Viability is largely lost in about 20 days in water at $20^{\circ} \mathrm{C}, 30$ days in water at $10^{\circ} \mathrm{C}$, and 90 days in water of only a few degrees Celsius (Wilson and others, 1992). Traveltime represents the residence time the water has in contact with the aquifer material, which may enhance the filtering efficiency of the aquifer material.

The most notable example of change started on February 28, 1993, in the Cedar River for specific conductance, $\mathrm{pH}$, and dissolved oxygen. The values for specific conductance and $\mathrm{pH}$ and the concentration of dissolved oxygen decreased with a corresponding increase in the discharge of the river. This decrease is subsequently seen in observation well CRM-4, municipal well Seminole 10 , and to a lesser extent in observation well CRM-3 and the municipal watertreatment plant. A traveltıme for water moving from the Cedar River to other sampling sites can be cstimated from the data. A traveltime is estimated by determining fiom the plotied or tabulated cata when a change starts in the river and counting the days until correlative changes occur at other at sampling sites. 
$\stackrel{0}{x} \frac{\mathfrak{O}}{x} \frac{3}{x} \frac{3}{x}$

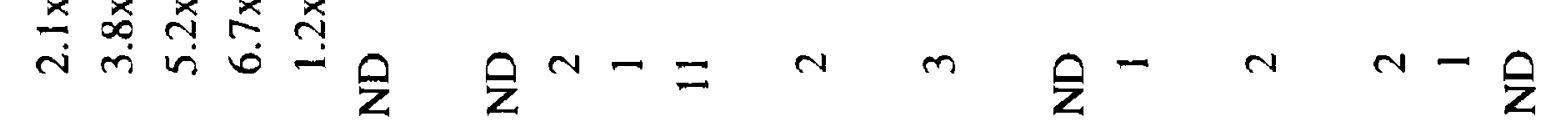

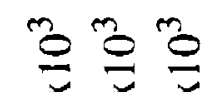

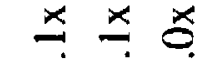

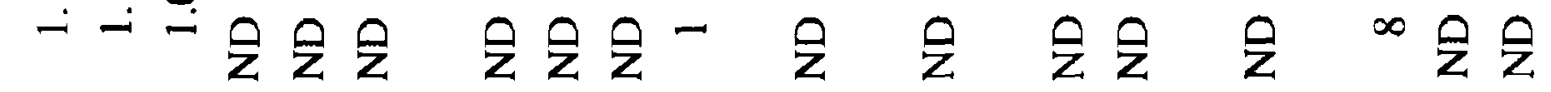

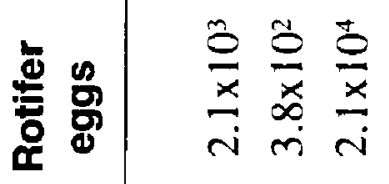

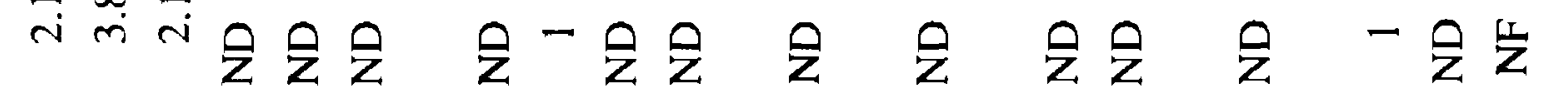

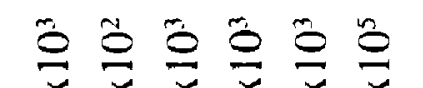

艾

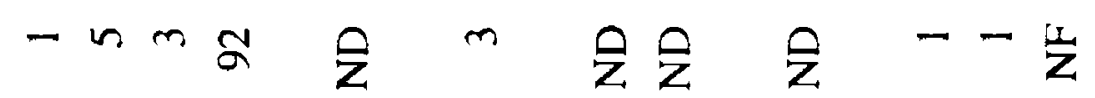

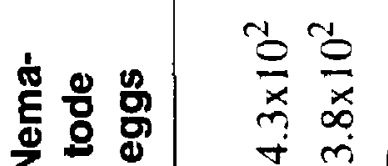

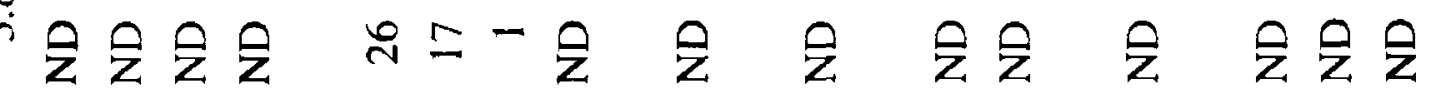

密弯

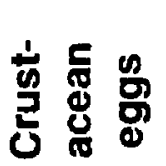

$\dot{r} \dot{m}-\dot{r}$

z 으을

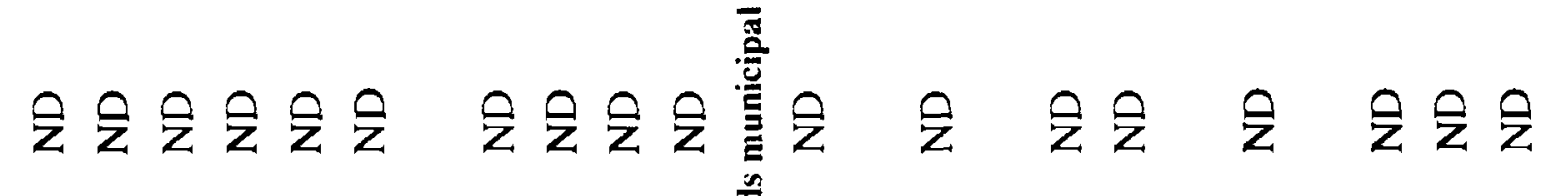

光

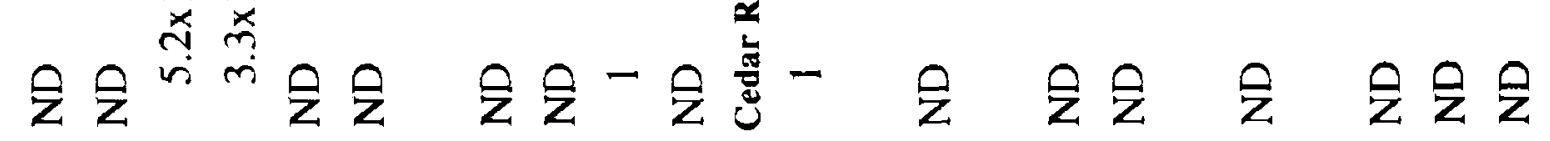

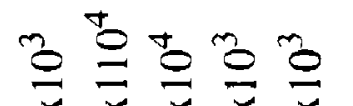

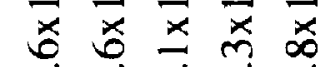

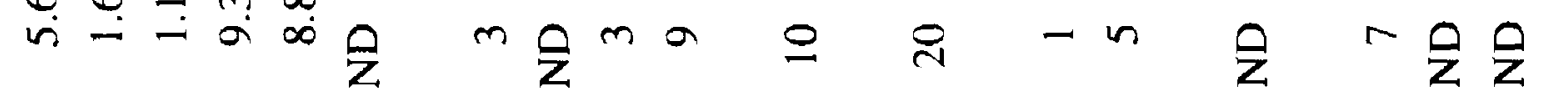

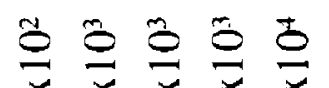

㐫

†े

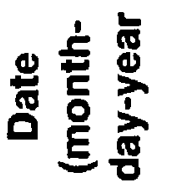

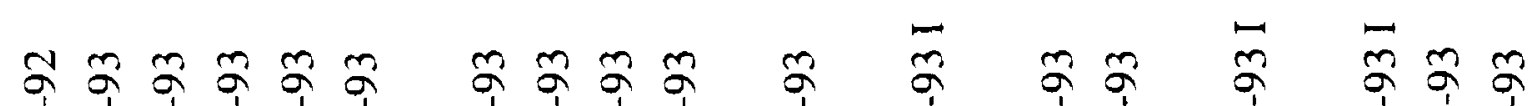

它它

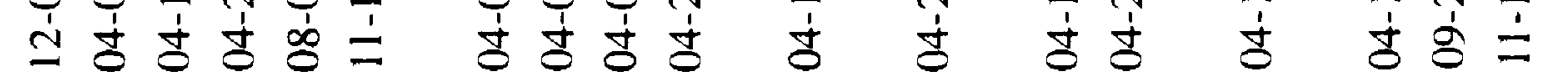

$\div$

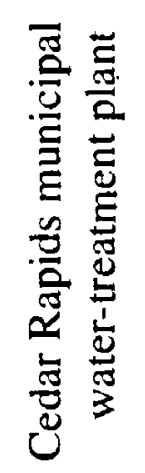

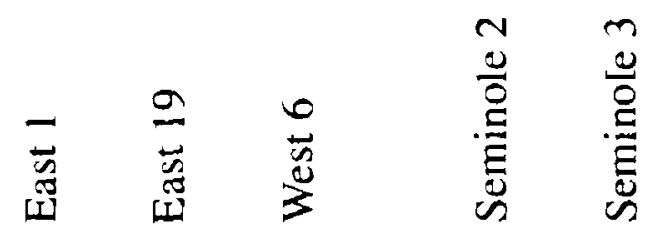




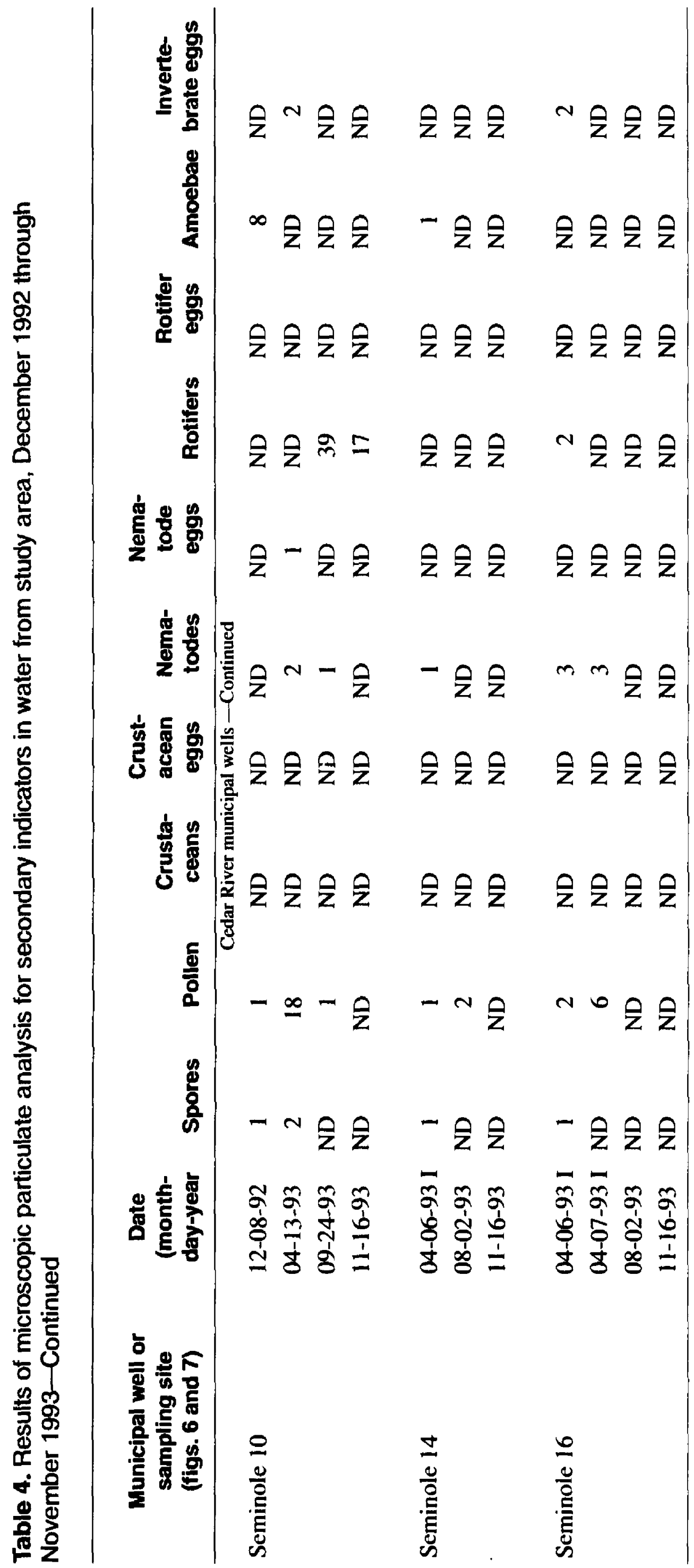




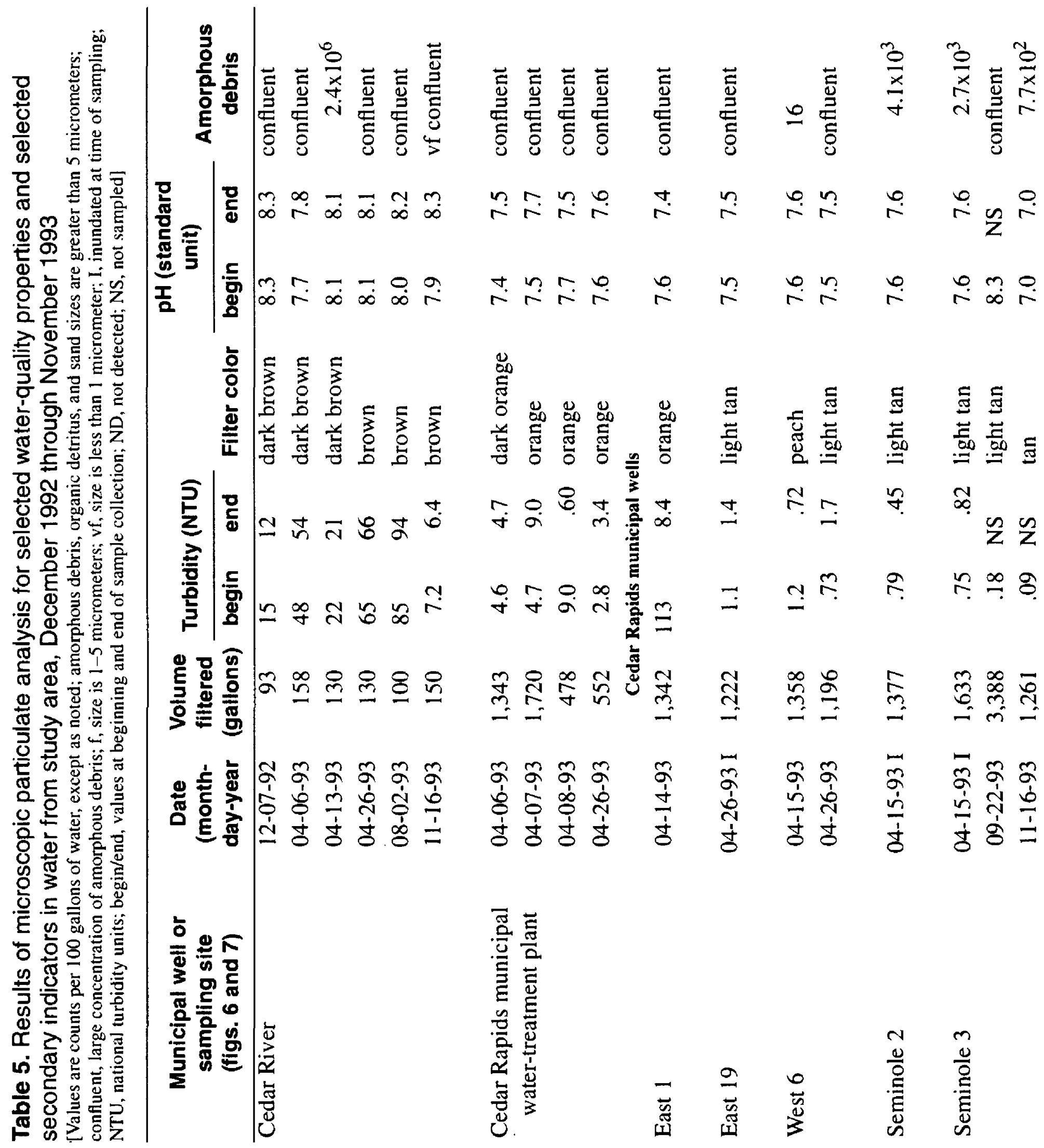




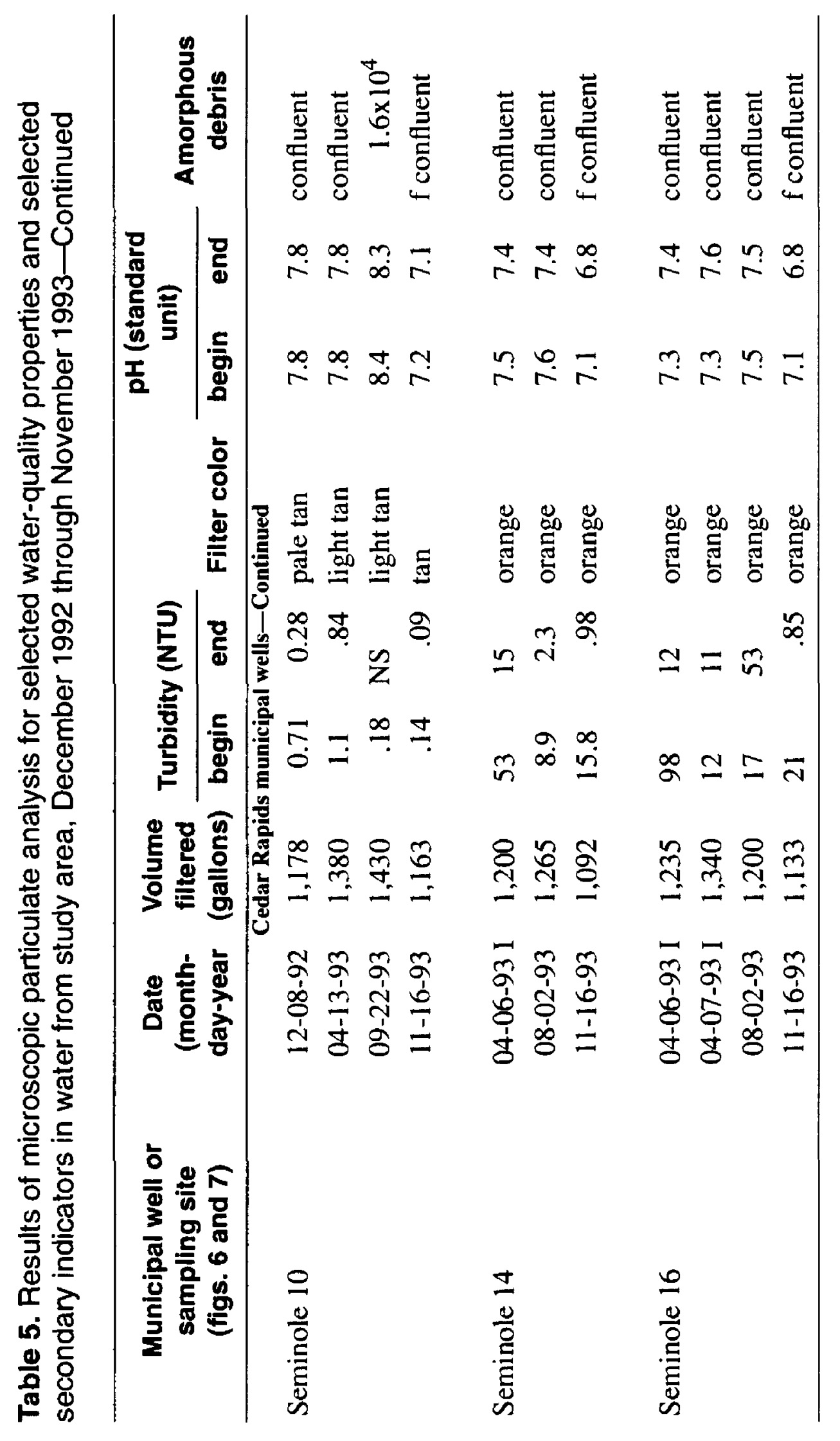




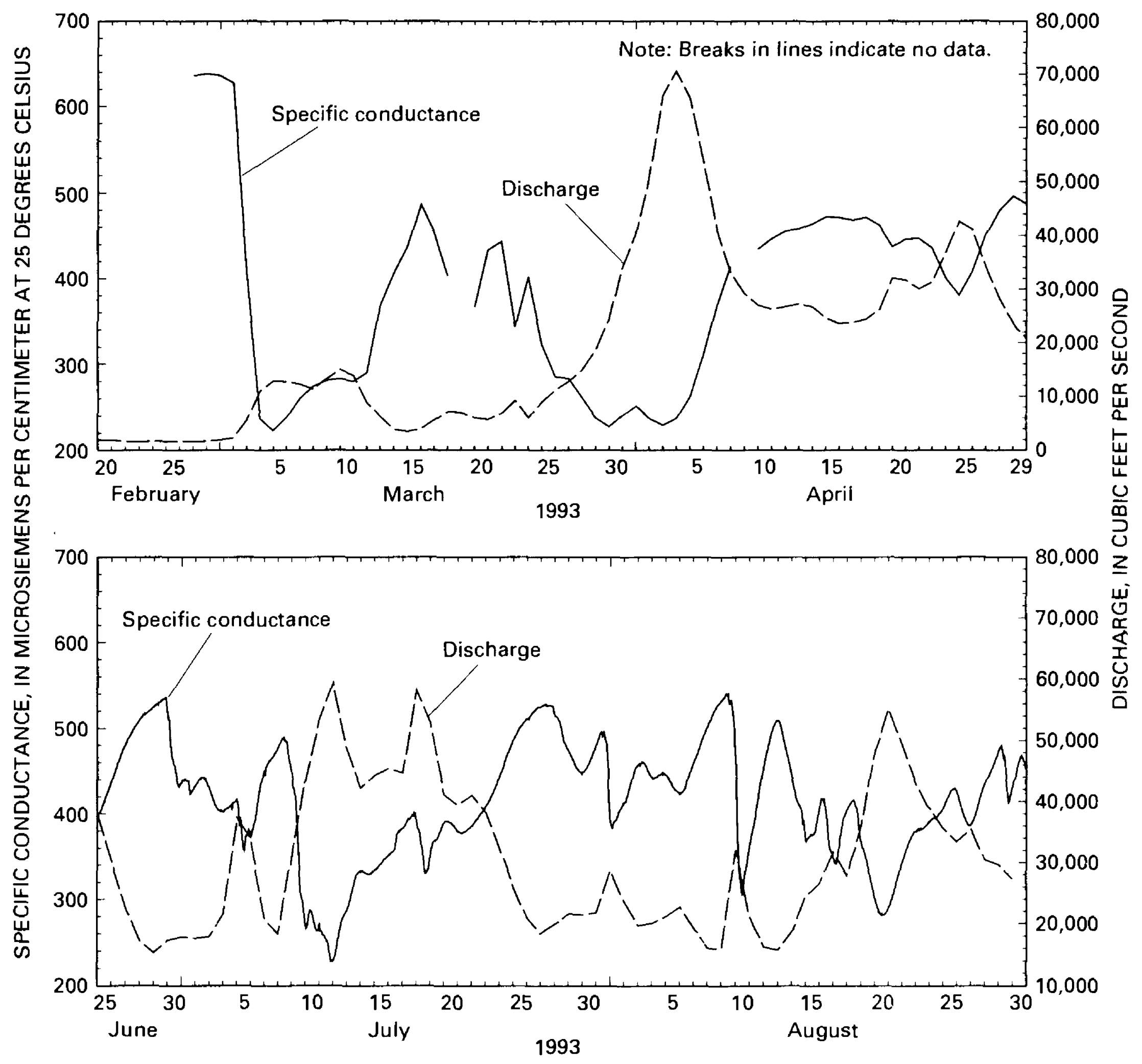

Figure 11. Specific conductance and discharge for the Cedar River at Cedar Rapids gaging station from February 20 through April 29 and June 25 through August 30, 1993.

\section{Specific Conductance}

Specific-conductance values for the Cedar River started to decrease on February 28, 1993, with a subse- quent decrease in values at observation well CRM-4 on March 4, 1993, and at municipal well Seminole 10 on March 7, 1993 (fig. 14). Water of lower specific conductance took 4 days to travel to well CRM- 4 and 


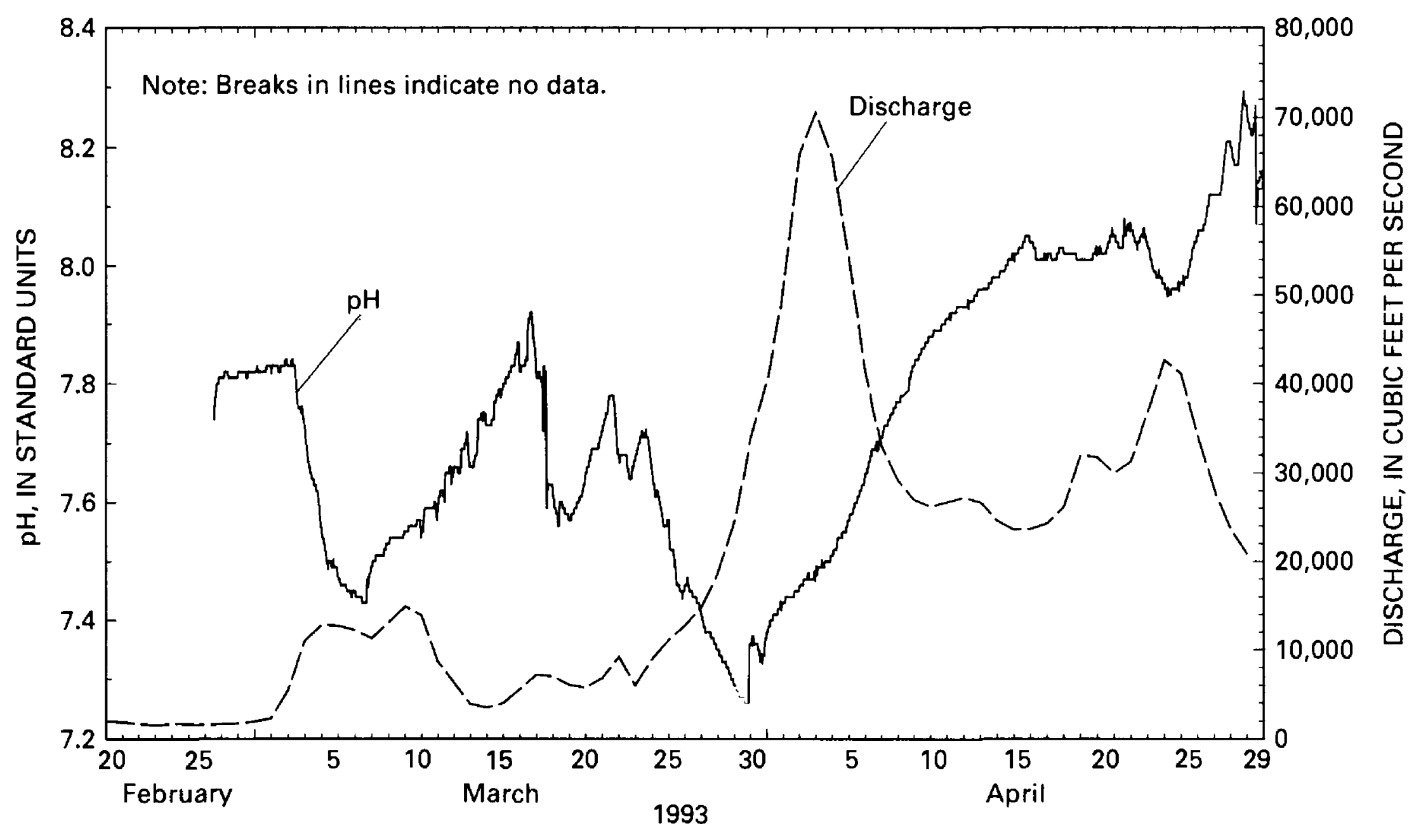

Figure 12. $\mathrm{pH}$ and discharge of the Cedar River at Cedar Rapids gaging station from February 20 through April 29, 1993.

7 days to travel to well Seminole 10. Three other selected events are shown starting on March 5 and October 2, 1993, and January 2, 1994, for the Cedar River. Traveltimes to well CRM-4 were 5, 5, and 4 days for observable changes to start at well CRM-4 and 12,7, and 9 days to start at well Seminole 10, respectively. Water at observation well CRM-3 had an estimated traveltime of 29 days from the river on February 28, 1993, based on a correlative change that occurred on March 29, 1993 (fig. 15). Water entering the municipal water-treatment plant generally follows the trend of specific-conductance values for the river, but abrupt changes that occur in the river are not apparent in the water-treatment plant and no correlation of changes was possible from the data.

\section{pH}

There is no obvious correlation between the change in $\mathrm{pH}$ of the Cedar River that can be traced 


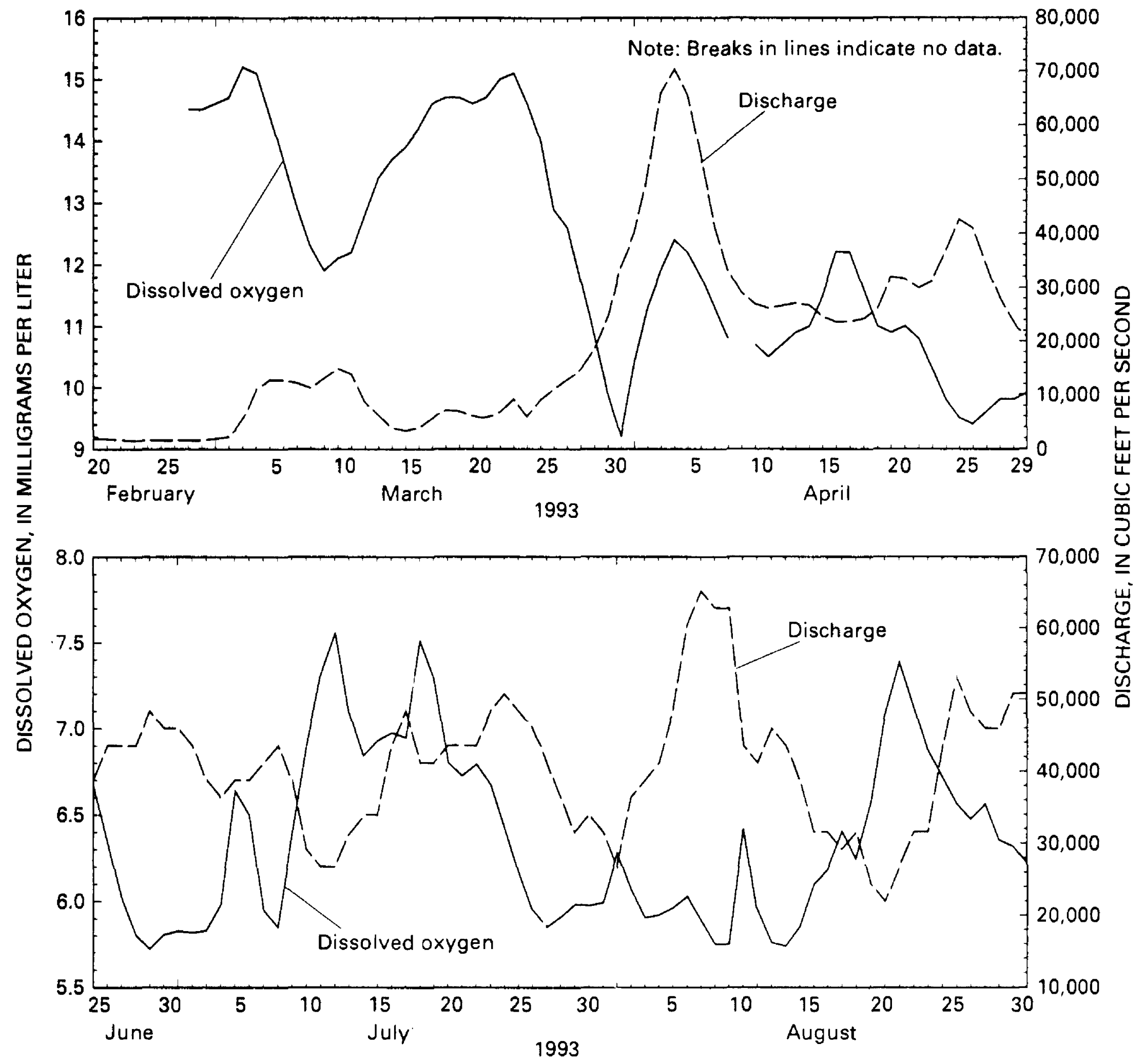

Figure 13. Dissolved oxygen and discharge of the Cedar River at Cedar Rapids gaging station from February 20 through April 30 and June 25 through August 30, 1993.

through the aquifer to municipal well Seminole 10 (fig. 16). This probably is due to the buffering capability of the aquifer material as water flows through the aquifer.

\section{Temperature}

Water temperature in the Cedar River followed the seasonal fluctuations of air temperature, colder in the winter and warmer in the summer. Temperatures of ground water tended to be more stable and depended on several factors: (1) the porosity of the aquifer, (2) the specific heat of the aquifer material, (3) the temperature of the ground water in storage, (4) the temperature of water in the river, and (5) the amount of mixing that occurred (Schneider, 1962). Water temperature for the Cedar River, observation well CRM-4, and municipal well Seminole 10 are shown in 


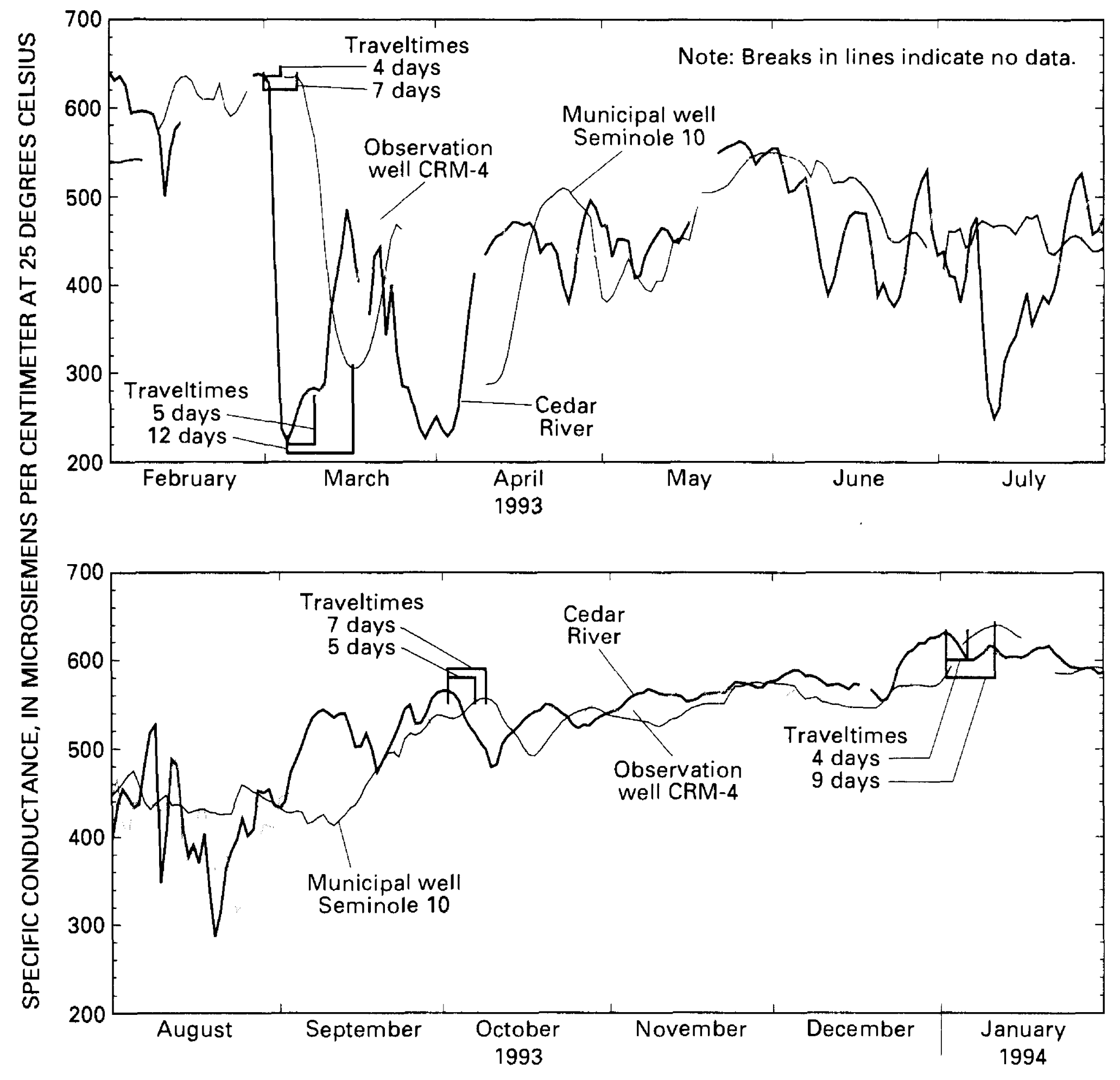

Figure 14. Specific conductance of water from the Cedar River, observation well CRM-4, and Cedar Rapids municipal well Seminole 10, and estimated traveltimes of water from the river to observation well CRM-4 and municipal well Seminole 10 , February 1, 1993, through January 31, 1994.

figure 17. Figure 18 , nows temperature for the Cedar River, observation well CRM-3, and water-treatment plant.

On March 2.t, 1993, the water temperature increased in the river, and a corresponding increase was observed in observation well CRM-4 on March 31, 1993 (fig. 17). Thus, the traveltime of water from the Cedar River to observation well CRM-4 is esti- mated to be 8 days. Similar estimates of traveltime from the Cedar River to observation well CRM-4 were made for August 27 to September 3. 1993, and from October 8 to October 15, 1993: both events had traveltimes of 7 days. Traveltimes for March 24 to April 11 , 1993. August 27 to September 13, 1993, and October 8 to October 18, 1993, ranged from 10 to 17 days. The traveltimes are not long enough to have a substantial 


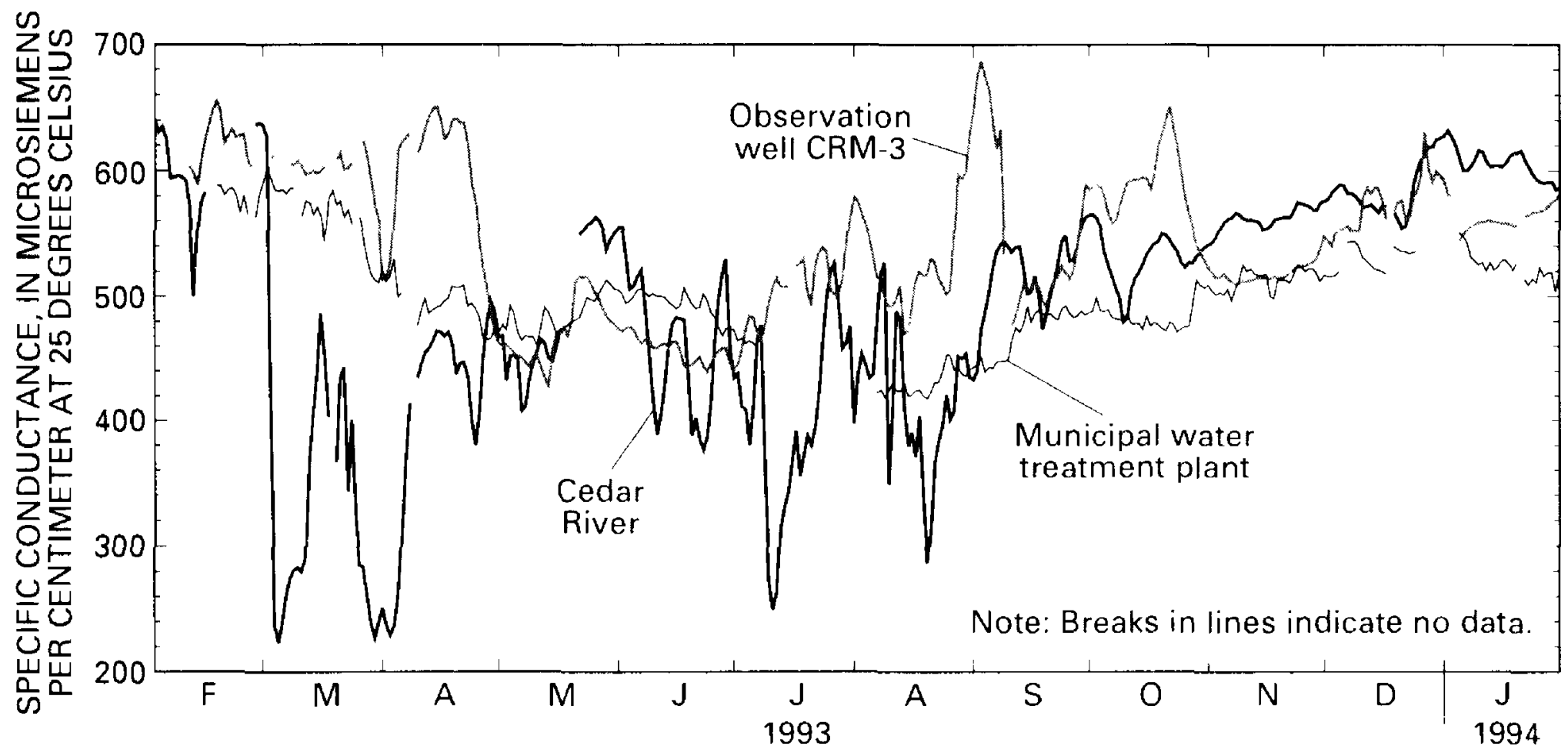

Figure 15. Specific conductance of water from the Cedar River, observation well CMR-3, and the municipal water-treatment plant, February 1, 1993, through January 31, 1994.

effect on the viability of Giardia cysts in water pumped by municipal well Seminole 10.

Water temperatures for observation well CRM-3 (fig. 18) do not corollate to the temperatures in the Cedar River. The maximum temperature for water in well CRM-3 was reached on December 2, 1993, at $18.7^{\circ} \mathrm{C}$ while the river water was at $0.8^{\circ} \mathrm{C}$.

Water temperature measured at the water-treatment plant (fig. 18) changed slowly from a minimum on April 10, 1993, to a maximum on September 13, 1993. A traveltime is estimated from March 24, 1993, when the water temperature in the river started to warm, to the minimum temperature observed at the water-treatment plant on April 10, 1993 ( 17 days). Traveltime from the maximum water temperature in the river on August 27, 1993, to the maximum water temperature on September 13, 1993. at the water-treatment plant is also 17 days. This is the same traveltime as the traveltime to municipal well Seminole 10 in April and in August. There were no rapid changes in water temperature observed at the municipal water-treatment plant.

\section{Dissolved Oxygen}

In a stream, dissolved oxygen is a function of the equilibrium concentration of dissolved oxygen and is controlled mainly by pressure and temperature at the contact between the atmosphere and the water surface (Hem, 1989). Some aquatic organisms require oxygen and may deplete concentrations of dissolved oxygen, whereas other organisms may increase the dissolvedoxygen concentration through photosynthesis. Concentrations of dissolved oxygen in ground water usually are the result of recharge to the aquifer, and concentrations can be similar to those of surface water (Hem, 1989). Dissolved-oxygen concentrations in water from the Cedar River, observation well CRM-4, and municipal well Seminole 10 are shown in figure 19, and in water from the Cedar River, observation well CRM-3, and municipal water-treatment plant are shown in figure 20.

Dissolved-oxygen concentrations in water from the Cedar River shows seasonal trends (fig. 19).

During the colder winter months, the concentration of dissolved oxygen is about $14 \mathrm{to} 15 \mathrm{mg} / \mathrm{L}$. During the summer months, dissolved-oxygen concentrations average 7 to $9 \mathrm{mg} / \mathrm{L}$ (table 28 ). Colder water can hold more dissolved oxygen than warmer water. Diurnal fluctuations were present throughout the study and probably result firom biological activity. Dissolvedoxygen concentrations in water from observation well 


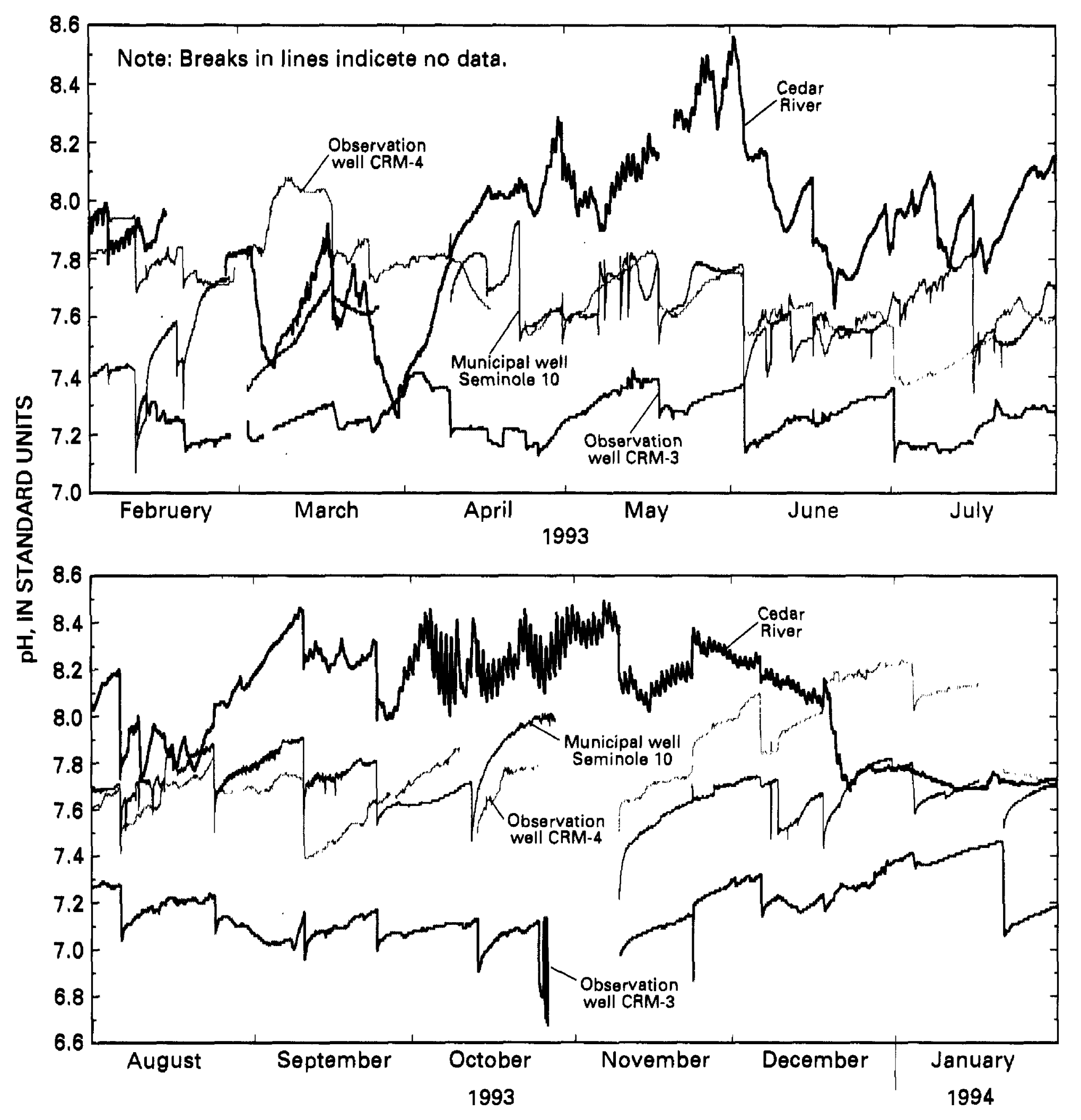

Flgure 16. $\mathrm{pH}$ of water from the Cedar River, observation wells CRM-3 and CRM-4, and Cedar Rapids municipal well Seminole 10, February 1, 1993, through January 31, 1994.

CRM-4 and CRM-3 and municipal well Seminole 10 are dependent on the biological activity in the alluvial aquifer material and the movement of surface water through the material. The concentration of dissolved oxygen has been found to decrease abruptly in the first $50-65 \mathrm{ft}$ of sediments as a result of mineralization of dissolved organic compounds by microorganisms
(Bourg and Bertin, 1993). This could account for the observed decrease of about 2 to $4 \mathrm{mg} / \mathrm{L}$ in the dissolved-oxygen concentration between the river and observation well CRM-4 (fig. 19) throughout the study period.

On March 9, 1993, the decreasing concentration of dissolved oxygen in water from the river ceased and 


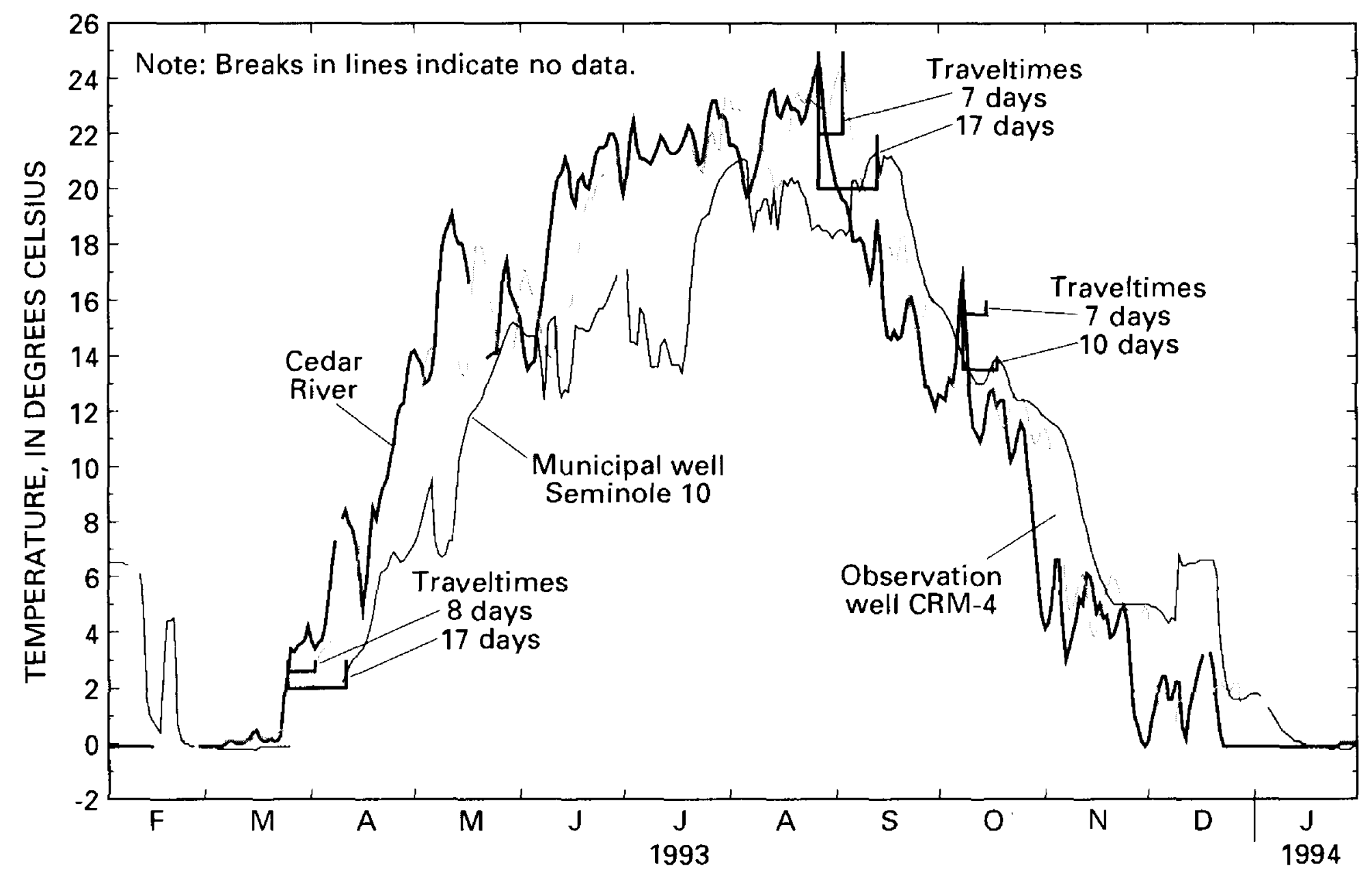

Figure 17. Temperature of water from the Cedar River, observation well CRM-4, and Cedar Rapids municipal well Seminole 10, and estimated traveltimes of water from the river to observation well CRM-4 and municipal well Seminole 10, February 1, 1993, through January 31, 1994.

started to increase. This change was observed on March 15, 1993, for observation well CRM-4 and on March 17 for municipal well Seminole 10 (fig. 19). Traveltimes based on these changes were 6 and 8 days, respectively. On November 1, 1993, the river concentration of dissolved oxygen stopped increasing. This change was observed on November 6, 1993, at well CRM-4 and on November 8, 1993, at well Seminole 10 , indicating ground-water traveltimes of 5 and 7 days, respectively.

The concentrations of dissolved oxygen in water from observation well CRM-3 (fig. 20) showed very little change compared with well CRM-4. This could be due to ground water of low concentrations of dissolved oxygen seeping up from a deeper aquifer. No traveltimes based on dissolved oxygen could be determined between the river and well CRM-3.

Dissolved-oxygen concentrations in water from the water-treatment plant show only small changes (fig. 20). There are three peaks shown on the graph (fig. 20) for the water-treatment plant on May 10, June 23, and November 14,1993, which could be a result of changes in the river on April 17, May 26, and November 1, 1993, respectively. These changes indicate traveltimes from the river to the watertreatment plant of 23,28 , and 13 days, respectively. The larger concentrations between July 17 and August 5,1993 , could be the result of algal growths in the pipe of the aeration tower in which the multiprobe was placed. 


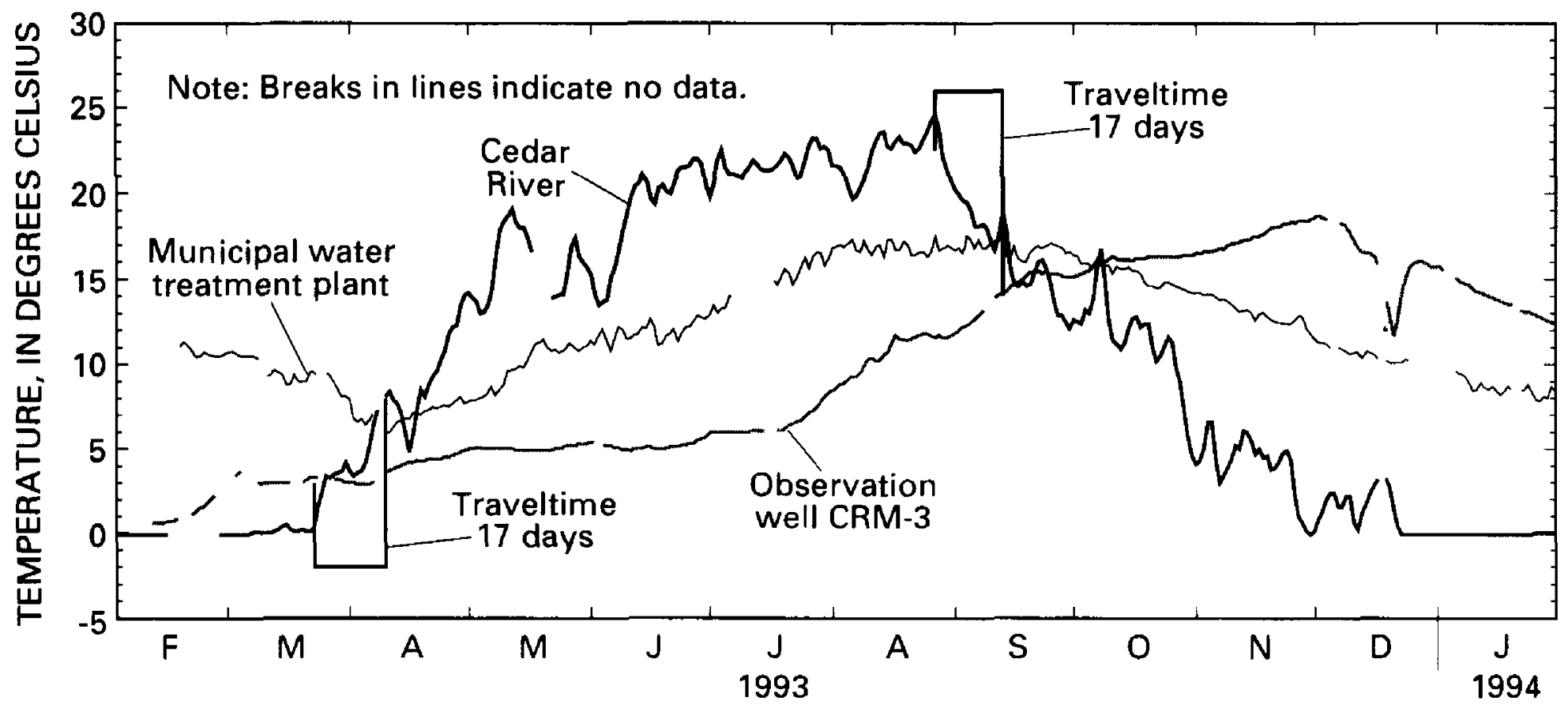

Figure 18. Temperature of water from the Cedar River, observation well CRM-3, and the municipal water-treatment plant, and estimated traveltimes of water from the river to observation well CRM-3, February 1, 1993, through January $31,1994$.

\section{ASSESSMENT OF RELATIVE RISK OF ALLUVIAL AQUIFER TO CONTAMINATION BY PATHOGENS}

The above-normal streamflow and precipitation during the study increased the effect of the Cedar River on the alluvial ground-water system and the potential for contamination by a pathogen. The increase in runoff could increase the amount of animal wastes reaching streams that could contribute to increased numbers of biogenic pathogens in the surface water. Several municipal wells were inundated for considerable periods of time during this study. With wells inundated, there could be a shorter path-from the ground surface down to the well screen-for biogenic pathogens to travel. However, several of the wells are completed through a silty clay and clay layer in the East Well Field (fig. 3) and a fine sandy silt layer in Seminole Well Field (fig. 5). These layers of relatively low hydraulic conductivity could help in restricting the movement of biogenic pathogens through the aquifer to the well.

The dissolved-oxygen data indicate that anaerobic conditions were not present in the alluvial aquifer in the vicinity of observation well CRM-4 and muni- cipal well Seminole 10. This lack of anaerobic conditions could allow a very active microbiological community to develop that could aid in the natural filtration process that occurs in the alluvial aquifer. Investigators are finding that microbial activity and diversity are much greater than once thought in aquifers and that lake bottoms, streambeds, and soil zones are similar to the biologically active surface layer, known as the schmutzdecke, in slow, sand-filter systems (Boria and others, 1992). This layer is thought to allow perdition to occur as part of the filtering process (Boria and others, 1992). The filtration process itself is complex and involves a combination of straining, interception, sedimentation, Brownian diffusion, hydrodynamic retardation, and surface-interaction forces (Boria and others, 1992). Ground-water supplies in porous-media (sand and gravel) aquifers that induce recharge from surface water through pumping generally can be considered low-risk situations for Giardia contamination (Boria and others, 1992).

Data from MPA were used to determine the relative risk factor of water from the municipal wells tested and the raw water prior to treatment at the municipal water-treatment plant. This is done by determining the numerical range of each of the bio- 


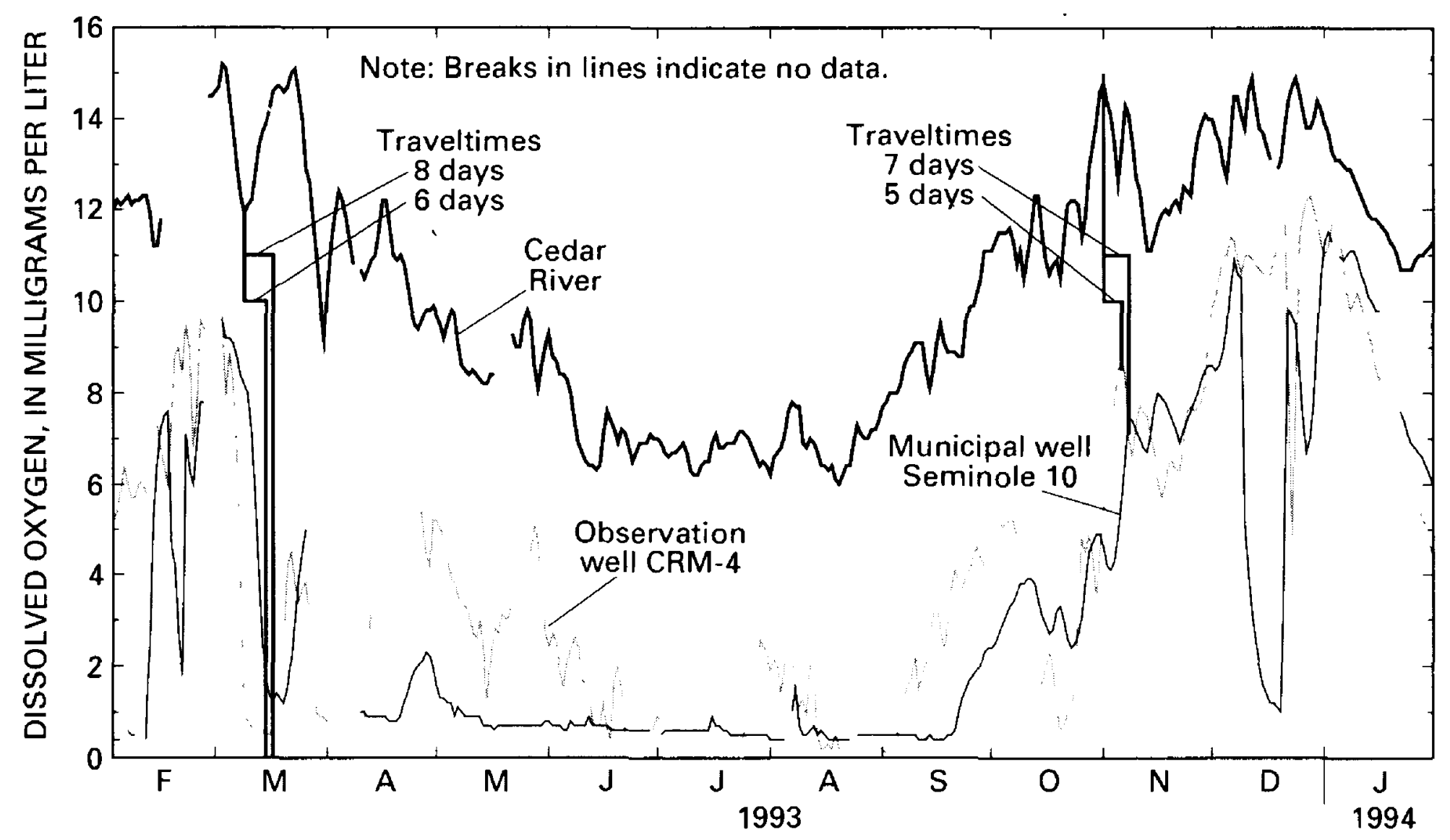

Figure 19. Concentrations of dissolved oxygen in water from the Cedar River, observation well CRM-4, and Cedar Rapids municipal well Seminole 10, and estimated traveltimes for water from the river to observation well CRM-4 and municipal well Seminole 10, February 1, 1993, through January 31, 1994.

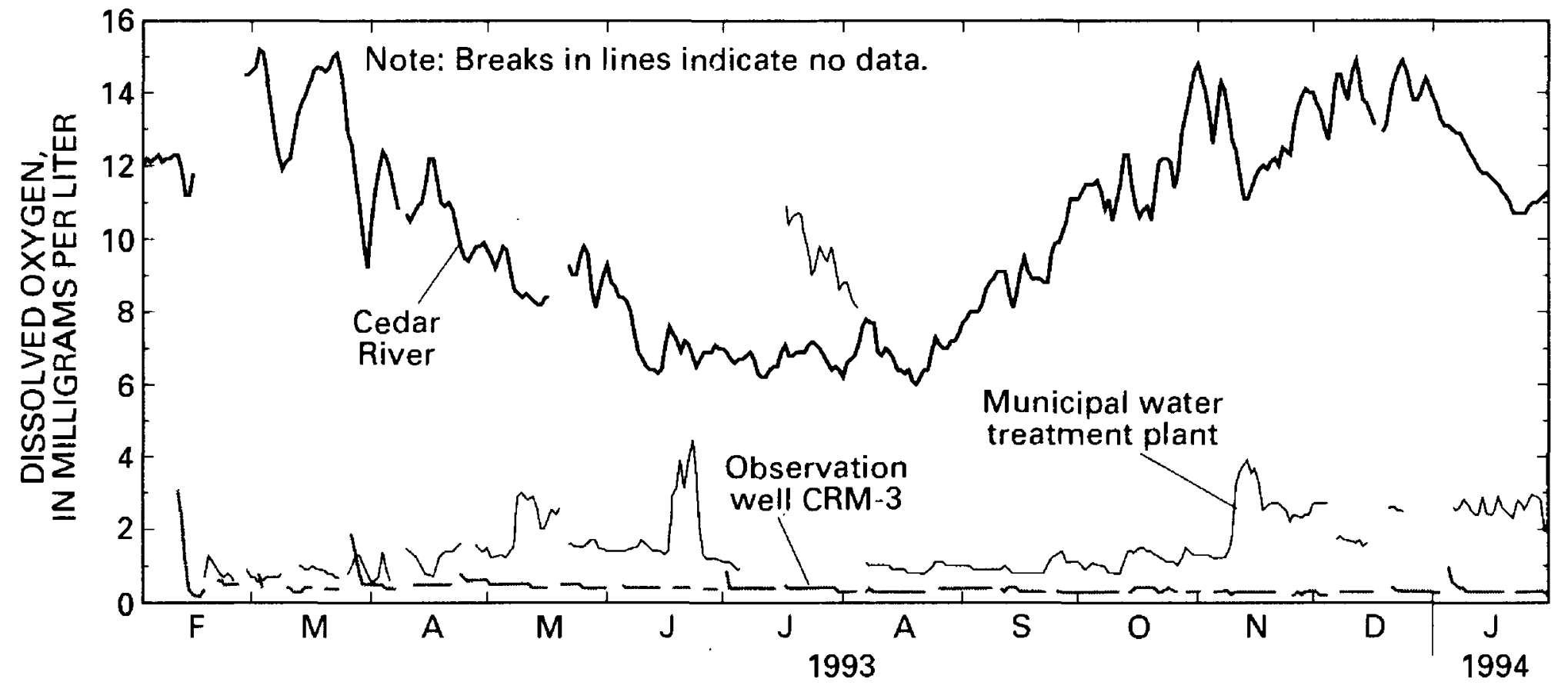

Figure 20. Concentrations of dissolved oxygen in water from the Cedar River, observation well CRM-3, and the Cedar Rapids municipal water-treatment plant, February 1, 1993, through January 31, 1994. 
Tabie 6. Risk of surface-water contamination as determined by microscopic particulate analysis of water in the study area, December 1992 through November 1993

[Information provided by Tom Noth of the Cedar Rapids Municipal Water Department]

\begin{tabular}{|c|c|c|c|}
\hline $\begin{array}{l}\text { Municipal wells or } \\
\text { sampling slte (figs. } 6 \text { and } 7 \text { ) }\end{array}$ & $\begin{array}{c}\text { Date } \\
\text { (month-day- } \\
\text { year) }\end{array}$ & $\begin{array}{c}\text { Risk } \\
\text { factor }\end{array}$ & $\begin{array}{c}\text { Risk of surface- } \\
\text { water } \\
\text { contamination }\end{array}$ \\
\hline \multirow[t]{6}{*}{ Cedar River } & $12-07-92$ & 77 & High risk \\
\hline & $04-06-93$ & 57 & High risk \\
\hline & $04-13-93$ & 37 & High risk \\
\hline & $04-26-93$ & 37 & High risk \\
\hline & $08-02-93$ & 18 & Moderate risk \\
\hline & $11-16-93$ & 74 & High risk \\
\hline \multirow{4}{*}{$\begin{array}{l}\text { Cedar Rapids municipal } \\
\text { water-treatment plant }\end{array}$} & $04-06-93$ & 21 & High risk \\
\hline & $04-07-93$ & 21 & High risk \\
\hline & $04-08-93$ & 15 & Moderate risk \\
\hline & $04-26-93$ & 17 & Moderate risk \\
\hline \multicolumn{4}{|c|}{ Cedar Rapids municipal wells } \\
\hline East 1 & $04-14-93$ & 4 & Low risk \\
\hline East 19 & $04-26-93$ & 5 & Low risk \\
\hline \multirow[t]{2}{*}{ West 6} & $04-15-93$ & 4 & Low risk \\
\hline & $04-26-93$ & 4 & Low risk \\
\hline Seminole 2 & $04-15-93$ & 4 & Low risk \\
\hline \multirow[t]{3}{*}{ Seminole 3} & $04-15-93$ & 21 & High risk \\
\hline & $09-22-93$ & 10 & Moderate risk \\
\hline & $11-16-93$ & 9 & Low risk \\
\hline \multirow[t]{4}{*}{ Seminole 10} & $12-08-92$ & 0 & Low risk \\
\hline & $04-13-93$ & 10 & Moderate risk \\
\hline & $09-22-93$ & 2 & Low risk \\
\hline & $11-16-93$ & 10 & Moderate risk \\
\hline \multirow[t]{3}{*}{ Seminole 14} & $04-06-93$ & 14 & Moderate risk \\
\hline & $08-02-93$ & 9 & Low risk \\
\hline & $11-16-93$ & 4 & Low risk \\
\hline \multirow[t]{4}{*}{ Seminole 16} & $04-06-93$ & 14 & Moderate risk \\
\hline & $04-07-93$ & 14 & Moderate risk \\
\hline & $08-02-93$ & 9 & Low risk \\
\hline & $11-16-93$ & 4 & Low risk \\
\hline
\end{tabular}


indicators tabulated in table 33 for a particular sample from tables 3 and 4 . A rating of extremely heavy (EH), heavy $(H)$, moderate $(M)$, rare $(R)$, or not significant (NS) is assigned to each bio-indicator of the sample. A numerical value then is assigned from table 34 for each bio-indicator according to its rating, and a sum is determined for the numerical values. A relative risk factor is determined from the scale at the bottom of table 34. A detailed explanation of the procedure is described in U.S. Environmental Protection Agency (1989).

Following this procedure, the river was evaluated to be at high risk (table 6) for the period of study due to the presence of Giardia cysts and Cryptosporidium oocysts and large counts of algae, diatoms, and rotifers (table 3 and 4). Of the eight municipal wells tested during the April 1993 flooding, municipal well Seminole 3 had a high-risk factor, three other wells had a moderate-risk factor, and four wells had a lowrisk factor (table 6). Five of the eight wells were inundated during this time (table 4), one at high risk, two at moderate risk, and two at low risk. For the remainder of the study period two wells had a moderate-risk factor at different times, and the rest of the wells sampled had a low-risk factor.

To measure the efficiency of the filtering process of the alluvial aquifer a log-reduction rate is used (Clancy, 1992). Using the particulate concentrations in table 4 for the wells and the river at concurrent times, a log-reduction rate can be calculated (table 7). The logreduction rate is calculated for an indicator by taking the log of the number of counts for the surface-water source (surface water) minus the log of the number of counts for the well. The log-reduction rate was calculated for vegetative debris, diatoms, and algae. Indicators that were not detected in both ground water and surface water were not used. If a ground-water sample had no detection for one of the indicators tested, a value of 1 was assumed to calculate the log-reduction rate.

The data for selected municipal wells tested show at least a three-log (99.9-percent) reduction between the river and the wells (table 7). A three-log (99.9-percent) reduction of algae is likely to achieve a three-log (99.9-percent) reduction in Giardia cysts (Boria and others, 1992). The log reduction for algae for municipal well Seminole 3 was 4.3 when it received it: high-risk rating on April 15, 1993. To date (1994), there has been no record of an outbreak of waterborne disease in the City of Cedar Rapids (John
North, City of Cedar Rapids Water Department, oral commun., 1994). A three-log (99.9-percent) reduction is required by the USEPA and the lowa Department of Natural Resources for filtration and disinfection (U.S. Environmental Protection Agency, 1989; Iowa Administrative Code, 1992). The log-reduction data obtained in this study show that the natural filtration of the alluvial aquifer is very effective.

The presence of algae in some of the wells could indicate an inadequate surface seal around the casing. Another possibility could be macropores caused by tree roots, which could enhance vertical seepage to the aquifer from flooded areas. Municipal wells Seminole 14 and 16 are near heavily wooded areas. The count of algae detected at the water-treatment plant in April 1993 was higher than at all of the eight wells sampled during April 1993 (table 3). Some of the wells tested had counts of less than 20 per 100 gal. Because the water sampled at the water-treatment plant is a mixture of water from many wells, the count of algae might be expected to be lower than the results from most individual wells, but this is not the case. Algae growing inside the pipe of the aeration tower, where the sample was collected, could be one explanation. The log reduction for the municipal water-treatment plant compared to the river water was less than three for 3 of 4 samples of algae and 2 of 4 samples of vegetative debris.

Counts of protozoa in samples are similar to those for algae. Large counts are found in the river with smaller counts for the wells and water-treatment plant. Larger counts were measured during the flooding in March of 1993 than at other times of the year.

\section{SUMMARY}

Alluvial aquifers adjacent to large streams are important sources of water for many municipalities. Alluvial aquifers can have large transmissivities and hydraulic conductivities, which make them very desirable for water supply because large amounts of water can be withdrawn. The Surface Water Treatment Rule under the 1986 Amendment to the Clean Water Act requires that public-water supplies be evaluated for susceptibility to surface-water effects (U.S.

Environmental Protection Agency, 1989). The groundwater source is evaluated for biogenic material and monitored for selected water-quality properties and constituents to determine the effect of surface water on the water supply. 


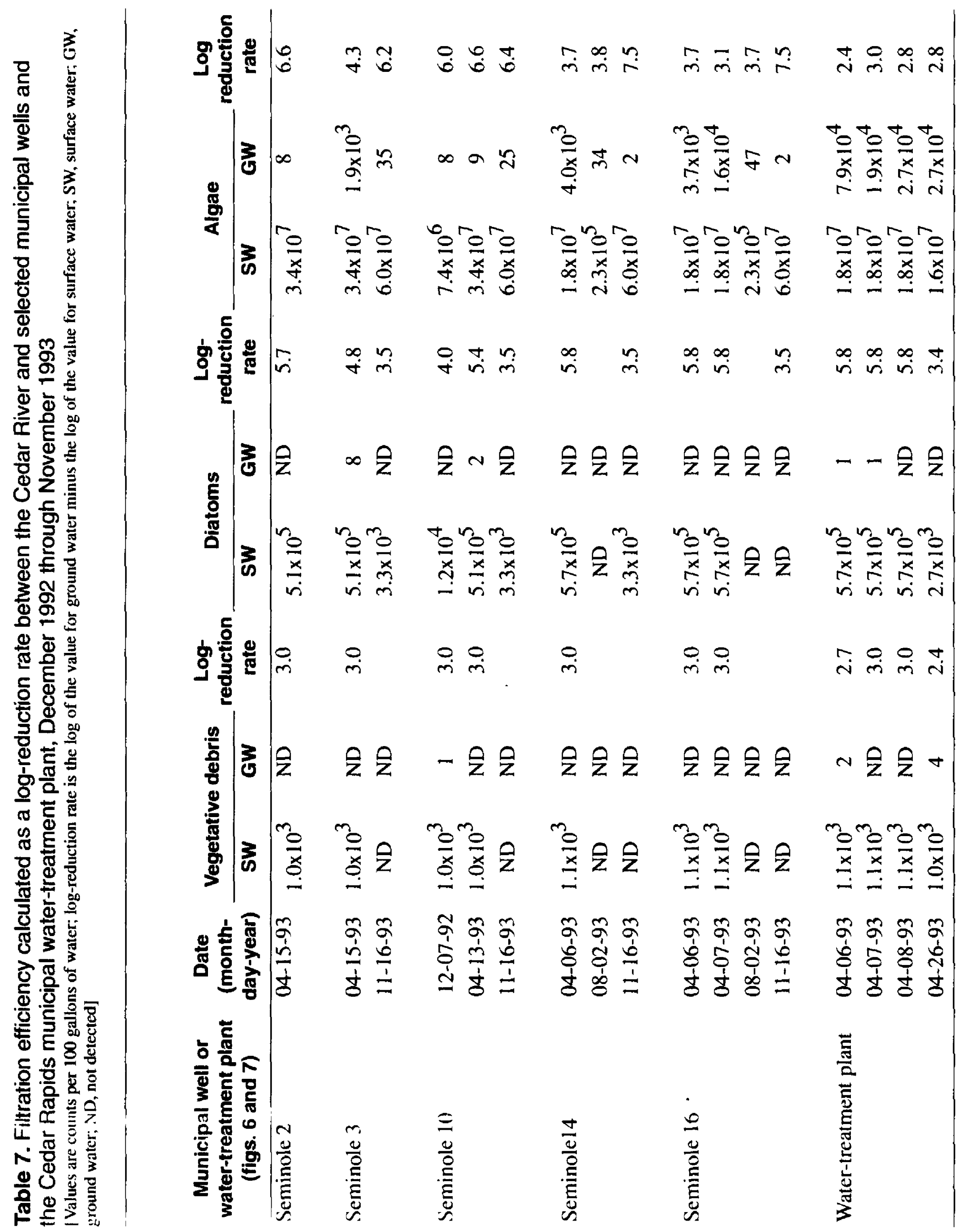


The City of Cedar Rapids uses the alluvial aquifer adjacent to the Cedar River for its drinking-water supply. The alluvial aquifer is hydraulically connected to the Cedar River, bedrock, and upland areas in the study area. The city has three well fields in use along the Cedar River (figs. 6 and 7) with a total of 53 municipal wells (table 2). The three well fields all have a similar lithologic sequence and hydraulic properties. A multiprobe instrument was used to continuously monitor water levels and selected waterquality properties and constituents in the Cedar River, observation wells CRM-3 and CRM-4, municipal well Seminole 10 (fig. 9), and selected water-quality properties and constituents at the municipal watertreatment plant (fig. 6).

Selected water-quality properties and constituents of the river changed inversely with changes in river stage or discharge (Schulmeyer, 1991). Selected water-quality properties and constituents of the alluvial aquifer changed as water flowed from the Cedar River to municipal well Seminole 10 as a result of drawdown. The values of specific conductance, $\mathrm{pH}$, temperature, and dissolved oxygen for observation well CRM-4 and municipal well Seminole 10 generally follow the trends of values for the Cedar River. Values of specific conductance, $\mathrm{pH}$, temperature, and dissolved oxygen at observation well CRM-3 and the municipal water-treatment plant show very little correlation with values for the Cedar River. The traveltime of water through the aquifer could be an indication of the susceptibility of the aquifer to surface-water effects. Estimated traveltimes from Cedar River to municipal well Seminole 10 ranged from 7 to 17 days. The data indicate that ground water has a short residence time in the aquifer before it is pumped out for consumption. Traveltimes were not long enough to have a substantial effect on the viability of Giardia cysts.

The above-normal conditions of streamflow and precipitation present during the study could have increased the effect that the Cedar River had on the alluvial aquifer and the possibility of contamination by a pathogen. The dissolved-oxygen data indicate that anaerobic conditions are not present in the alluvial aquifer in the vicinity of observation well CRM-4 and municipal well Seminole 10. This lack of anaerobic conditions could allow a very active microbiological community to develop, which could aid in the natural filtration process that occurs in the alluvial aquifer. Microscopic particulate data were collected using the method outlined by the USEPA to determine if a ground-water source is GWUDI according to the SWTR (Vasconcelos and Harris, 1992). Analysis of 29 samples found no Giardia cysts or Crytosporidium oocysts in water collected from municipal wells and the municipal water-treatment plant.

Data from the MPA were used to determine the relative risk factor of the ground-water source and the $\log$-reduction rate, a measure of the efficiency of the filtering process of the alluvial aquifer. Using MPA data it was determined that, of the eight municipal wells tested during the April 1993 flooding, one municipal well, Seminole 3, had a high-risk factor, three other wells had a moderate-risk factor, and four wells had a low-risk factor. Data indicate that the aquifer is filtering out large numbers of algae, diatoms, rotifers, and nematodes as well as filtering out Cryptosporidium, Giardia and other protozoa. The filtering efficiency of the aquifer is equivalent to a $3 \log$-reduction rate or 99.99 -percent reduction in particulates.

\section{REFERENCES CITED}

Boria, W.T., Wilson, M.P., and Gollnitz, W.D., 1992, Natural filtration in porous media aquifers: American Water Works Association, Proceedings, Water Quality Technology Conference, November 15-19, Toronto, Ontario, p. 1871-1888.

Bourg, A.C.M. and Bertin, C., 1993, Biogeochemical processes during the infiltration of river water into an alluvial aquifer: Environmental Science and Technology, v. 27, no. 4, p. 661-666.

Clancy, J.L., 1992, Interpretation of microscopic particulate analysis-A water quality approach: American Water Works Association Water, Proceedings, Quality Technical Conference, November 15-19, Toronto, Ontario, p. 1831-1847.

Freeze, R.A., and Cherry, J.A., 1979, Groundwater: Englewood Cliffs, N.J., Prentice Hall, 604 p.

Hansen, R. E., 1970, Geology and ground-water resources of Linn County, Iowa: Des Moines, Iowa Geological Survey Water-Supply Bulletin 10,66 p.

Heath, R. C., 1987, Basic ground-water hydrology: U.S. Geological Survey Water-Supply Paper 2220, p. $60-61$.

Hem, J.D., 1989, Study and interpretation of the chemical characteristics of natural waters ( $3 \mathrm{~d}$ ed.): U.S. Geological Survey Water-Supply Paper 2254, 263 p.

Hydrolab Corporation, 1991, DataSonde@3, Multiparameter water quality datalogger-Operating manual: Austin, Texas, Hydrolab Corporation, 83 p. 
Iowa Administrative Code, 1992, Water supplies-Design and operation: Des Moines, lowa, Environmental Protection[567], chap. 43, v. XI, IAC 10/14/92, 30 p.

lowa Department of Environmental Quality, 1976, Water quality management plan, Iowa-Cedar River basin: Des Moines, Planning and Analysis Section, Water Quality Management Division, $376 \mathrm{p}$.

Last, M.D., 1994, Giardia and Cryptosporidium-flood connection?: Lab Hotline, Hygienic Laboratory, The University of Iowa, v. 32 , no. 10, p. 1-2.

Prior, J.C., 1991, Landforms of Iowa: Iowa City, University of Iowa Press, $153 \mathrm{p}$.

Reading, H. G., 1978, Sedimentary environments and facies: Oxford, England, Blackwell Scientific Publications, $34 \mathrm{p}$.

Schneider, Robert, 1962, An application of thermometry to the study of ground water: U.S. Geological Survey Water-Supply Paper 1544-B, $16 \mathrm{p}$.

Schulmeyer, P.M., 1991, Relation of selected water-quality constituents to river stage in the Cedar River, Iowa: U.S. Geological Survey Toxic Substances Hydrology Program, Proceedings of the Technical Meeting, Monterey, California, March 11-15, 1991, p. 227-231.

Southard, R. E., Sneck-Fahrer, D., Anderson, C.J., Goodrich, R.D., and Gorman, J.G., 1994, Water resources data, Iowa, water year 1993: U.S. Geological Survey Water-Data Report, IA-93-1, 388 p.
Squillace, P. J., Liszewski, M. J., and Thurman, E. M., 1993, Agricultural chemical interchange between ground water and surface water, Cedar River Basin, Iowa and Minnesota-A study description: U.S. Geological Survey Open-File Report 92-85, p. 26.

U.S. Department of Agriculture, 1976, lowa-Cedar Rivers basin study: Des Moines, Iowa, $250 \mathrm{p}$.

U.S. Environmental Protection Agency, 1989, Guidance manual for compliance with the filtration and disinfection requirements for public water systems using surface water sources: Washington, D.C., $400 \mathrm{p}$.

Vasconcelos, Jay, and Harris, Stephanie, 1992, Consensus method for determining groundwaters under the direct influence of surface water using microscopic particulate analysis: Washington, D.C., U.S. Environmental Protection Agency, $52 \mathrm{p}$.

Wahl, Ken, and Bunker, B. J., 1986, Hydrology of carbonate aquifers in southwestern Linn County and adjacent parts of Benton, Iowa and Johnson Counties, Iowa: Des Moines, Iowa Geological Survey Water Supply Bulletin 15, 56 p.

Wilson, M.P., Gollnitz, W.D., and Boria, W.T., 1992, Temporal concepts in ground water transmission of Giardia cysts and other microscopic particulates: American Water Works Association, Proceedings, Water Quality Technology Conference, November 15-19, Toronto, Ontario, p. 1859-1869. 
Table 8. Mean daily water levels in the Cedar River at the surface-water monitoring site, February 1, 1993, through January 31, 1994

[Water levels given in feet above sea level; ---, no data]

\begin{tabular}{|c|c|c|c|c|c|c|c|c|c|c|c|c|}
\hline Day & Feb. & Mar. & Apr. & May & June & July & Aug. & Sept. & Oct. & Nov. & Dec. & Jan. \\
\hline 1 & 717.07 & 716.35 & 725.25 & 719.90 & 717.93 & 720.60 & 721.79 & 721.57 & 717.26 & 717.28 & 718.56 & 718.34 \\
\hline 2 & 717.20 & 716.09 & 727.56 & 719.65 & 718.08 & 720.46 & 720.86 & 721.33 & 717.48 & 717.19 & 717.32 & 718.84 \\
\hline 3 & 717.18 & 717.97 & 730.14 & 720.19 & 718.70 & 720.49 & 720.36 & 721.40 & 717.16 & 716.86 & 716.97 & 718.80 \\
\hline 4 & 717.32 & 720.74 & 730.49 & 719.93 & 719.25 & 721.08 & 720.69 & 720.99 & 717.00 & 716.53 & 716.64 & 718.80 \\
\hline 5 & 717.22 & 721.44 & 729.35 & 720.52 & 719.74 & 723.01 & 720.82 & 720.60 & 717.24 & 716.83 & 716.50 & 718.56 \\
\hline 6 & 717.04 & 721.52 & 727.28 & 720.88 & 719.92 & 722.40 & 720.97 & 720.04 & 717.00 & 717.15 & 716.80 & 718.38 \\
\hline 7 & 716.78 & 722.06 & 724.74 & 721.78 & 719.94 & 721.02 & 720.41 & 719.48 & 716.78 & 717.05 & 716.82 & 718.51 \\
\hline 8 & 716.95 & 723.01 & 722.90 & 722.21 & 720.14 & 720.69 & 719.43 & 718.88 & 716.56 & 717.20 & 716.80 & 718.45 \\
\hline 9 & 716.88 & 722.24 & --- & 722.12 & 720.89 & 723.05 & 719.02 & 718.32 & 717.12 & 717.34 & 716.42 & 718.43 \\
\hline 10 & 717.23 & 721.02 & 721.75 & 721.74 & 721.66 & 724.90 & 722.40 & 718.47 & 717.85 & 717.24 & 716.58 & 718.15 \\
\hline 11 & 717.78 & 720.87 & 721.52 & 721.36 & 722.65 & 726.42 & 720.72 & 718.15 & 717.84 & 716.94 & 717.05 & 718.33 \\
\hline 12 & 717.19 & 719.41 & 721.90 & 720.73 & 723.49 & 727.14 & 719.45 & 717.58 & 717.59 & 716.79 & 716.54 & 718.05 \\
\hline 13 & 717.06 & 717.72 & 721.83 & 720.67 & 723.33 & 725.55 & 719.59 & 717.59 & 717.57 & 716.59 & 716.42 & 717.94 \\
\hline 14 & 717.16 & 717.64 & 721.40 & 720.58 & 722.81 & 724.88 & 720.33 & 718.06 & 717.38 & 716.88 & 716.52 & 718.05 \\
\hline 15 & -.. & 717.02 & 720.76 & 720.91 & 722.16 & 725.33 & 721.53 & 718.76 & 717.17 & 717.24 & 716.68 & 718.15 \\
\hline 16 & -- & 716.76 & 720.81 & 720.89 & 721.28 & 725.33 & 721.90 & 718.79 & 717.03 & 717.26 & 716.90 & 717.67 \\
\hline 17 & --- & 718.26 & 721.22 & 720.30 & 720.86 & 725.08 & 722.64 & 718.77 & 717.02 & 717.23 & 716.78 & 717.65 \\
\hline 18 & --- & 718.70 & 721.17 & --- & 720.98 & 727.09 & 722.10 & 719.05 & 717.19 & 717.02 & --- & 717.84 \\
\hline 19 & --- & 718.17 & 721.16 & --- & 721.36 & 725.88 & 723.75 & 719.05 & 717.21 & 716.81 & 716.71 & 717.74 \\
\hline 20 & $\cdots$ & 717.87 & 722.61 & --- & 722.73 & 724.44 & 726.00 & 718.66 & 717.00 & 716.97 & 716.67 & 717.95 \\
\hline 21 & -- & 717.68 & 722.88 & $\cdots$ & 722.44 & 724.35 & 727.02 & 718.74 & 717.16 & 716.88 & 716.52 & 717.67 \\
\hline 22 & --- & 717.85 & 722.34 & 718.23 & 723.22 & 724.51 & 725.74 & 718.58 & 717.34 & 717.10 & 716.65 & 717.44 \\
\hline 23 & --- & 718.65 & 722.21 & 717.84 & 724.13 & 723.76 & 724.63 & 718.60 & 717.10 & 716.92 & 717.89 & 717.26 \\
\hline 24 & -- & 717.63 & 723.21 & 717.97 & 724.66 & 722.59 & 724.05 & 718.22 & 716.82 & 717.10 & 718.74 & 717.28 \\
\hline 25 & --- & 718.85 & 724.85 & 718.15 & 724.35 & 721.26 & 723.51 & 717.97 & 716.74 & 717.14 & 718.10 & 717.29 \\
\hline 26 & --- & 719.79 & 724.61 & 717.96 & 722.98 & 720.39 & 723.17 & 718.49 & 716.83 & 717.03 & 717.90 & 717.35 \\
\hline 27 & 716.65 & 720.22 & 722.94 & 717.71 & 721.42 & 719.73 & 723.41 & 718.57 & 716.69 & 716.79 & 718.32 & 716.92 \\
\hline 28 & 716.55 & 720.68 & 721.79 & 718.00 & 720.40 & 720.13 & 722.50 & 718.44 & 716.26 & 716.79 & 718.53 & 716.95 \\
\hline 29 & $-\cdots$ & 721.41 & 720.84 & 718.36 & 719.74 & 720.72 & 722.13 & 718.33 & 717.04 & 717.07 & 718.44 & 717.20 \\
\hline 30 & --- & 722.41 & 720.25 & 717.94 & 720.38 & 720.68 & 721.47 & 717.69 & 717.23 & 717.88 & 718.54 & 717.67 \\
\hline 31 & --- & 723.70 & $\cdots$ & 718.03 & $\cdots$ & 720.69 & 721.65 & -- & 717.23 & $\cdots$ & 718.35 & 717.55 \\
\hline Mean & 717.08 & 719.47 & 723.44 & 719.80 & 721.39 & 723.02 & 722.07 & 718.97 & 717.13 & 717.04 & 717.26 & 717.91 \\
\hline $\begin{array}{l}\text { Max- } \\
\text { imum }\end{array}$ & 717.78 & 723.70 & 730.49 & 722.21 & 724.66 & 727.14 & 727.02 & 721.57 & 717.85 & 717.88 & 718.74 & 718.84 \\
\hline $\begin{array}{l}\text { Min- } \\
\text { imum }\end{array}$ & 716.55 & 716.09 & 720.25 & 717.71 & 717.93 & 719.73 & 719.02 & 717.58 & 716.26 & 716.53 & 716.42 & 716.92 \\
\hline
\end{tabular}


Table 9. Mean daily water levels in observation well CRM-4, February 1, 1993, through January 31, 1994 [Water levels given in feet above seu level; ---, no data]

\begin{tabular}{|c|c|c|c|c|c|c|c|c|c|c|c|c|}
\hline Day & Fab. & Mar. & Apr. & May & June & July & Aug. & Sept. & Oct. & Nov. & Dec. & Jan. \\
\hline 1 & 717.33 & --. & ... & 718.26 & 716.40 & --. & --. & --- & 716.38 & 716.49 & 715.99 & 715.51 \\
\hline 2 & 717.45 & ... & -.- & 717.98 & 716.47 & --. & --- & --- & 716.57 & 716.39 & 715.05 & 715.99 \\
\hline 3 & 717.44 & -.. & $\ldots$ & 718.42 & 717.13 & --. & 719.42 & -- & 716.22 & 716.08 & 714.71 & 716.04 \\
\hline 4 & 717.55 & ... & ... & 718.16 & 717.67 & --- & 719.69 & --- & 716.05 & 715.56 & 714.34 & --. \\
\hline 5 & 717.43 & ... & --. & 718.70 & 718.19 & -.. & $\cdots$ & --- & 716.24 & 715.60 & 714.10 & 715.97 \\
\hline 6 & 717.26 & --. & --. & 719.03 & 718.44 & --. & --. & 719.32 & 715.97 & 715.88 & 714.37 & 715.77 \\
\hline 7 & 717.00 & --. & --. & -.. & -- & --- & --. & 718.84 & 715.76 & 715.74 & 714.38 & 715.99 \\
\hline 8 & 717.17 & -.. & --- & -.. & --- & --- & --- & 718.42 & 715.55 & 715.90 & 714.60 & 715.78 \\
\hline 9 & $\cdots$ & -- & $\ldots$ & $\ldots$ & 719.16 & --. & -.- & 717.80 & 716.06 & 715.68 & 714.31 & 715.73 \\
\hline 10 & -- & -- & -- & -- & $\cdots$ & $\cdots$ & -- & 717.84 & -- & 715.23 & 715.97 & 715.43 \\
\hline 11 & --. & --- & --. & --- & --- & -.. & --- & 717.44 & --- & 714.94 & 716.41 & 715.63 \\
\hline 12 & -.- & .-- & --. & -.. & --. & -.. & --- & 716.82 & -.- & 714.77 & 715.90 & 715.35 \\
\hline 13 & -.. & --- & --. & ... & ... & --- & --. & 716.77 & -.. & 714.38 & 715.80 & 715.24 \\
\hline 14 & -.. & --. & --. & 719.22 & -.. & $\cdots$ & -.. & 717.39 & 716.48 & 714.70 & 715.90 & 715.38 \\
\hline 15 & $\cdots$ & ..- & 719.10 & 719.53 & --- & --. & $\cdots$ & 717.86 & 716.27 & 715.04 & 716.06 & 715.54 \\
\hline 16 & --. & --- & 719.13 & 719.51 & --- & --- & --. & 717,94 & 716.09 & 715.09 & 716.27 & 715.00 \\
\hline 17 & --. & --- & --. & 718.89 & --- & --. & --. & 717.90 & 716.07 & 715.32 & 716.17 & 715.01 \\
\hline 18 & --- & $\cdots$ & --- & 718.16 & --- & --- & -.. & 718.12 & 716.21 & 715.14 & 716.11 & --- \\
\hline 19 & -.- & -- & -.- & 717.71 & --. & --. & --. & 718.13 & 716.23 & 714,87 & 716.11 & --- \\
\hline 20 & --. & --- & -- & 717.30 & -- & $-\cdots$ & --- & 717.73 & 716.03 & 714.97 & 716.05 & --- \\
\hline 21 & ..- & $\ldots$ & -.- & 717.01 & $\ldots$ & -.. & -.- & 717.52 & 716.16 & 714.73 & 714.63 & -..- \\
\hline 22 & -- & $\ldots$ & .-. & 716.70 & $\ldots$ & -.. & -.. & 717.13 & 716.19 & 714.95 & 713.90 & 714.41 \\
\hline 23 & --. & -- & -- & 716.29 & -- & --. & --. & 717.14 & 715.87 & 714.76 & 714.75 & 714.19 \\
\hline 24 & --- & -- & --. & 716.42 & -- & --- & -.- & 716.97 & 715.60 & 714.94 & 715.73 & 714.30 \\
\hline 25 & --. & --. & --- & 716.62 & --- & --- & --- & 716.80 & 715.51 & 714.94 & 715.41 & 714.38 \\
\hline 26 & -.. & 717.14 & --- & 716.44 & --- & --- & -- & 717.24 & 715.66 & 714.81 & 715.17 & 714.36 \\
\hline 27 & -.- & 717.53 & --. & 716.22 & --. & 719.15 & -.- & 717.30 & 715.76 & 714.54 & 715.66 & 713.92 \\
\hline 28 & -.. & 718.03 & -- & 716.49 & -- & 719.37 & -- & 717.19 & 715.66 & 714.53 & 715.82 & 713.92 \\
\hline 29 & --. & 718.80 & $\cdots$ & 716.82 & 719.22 & --- & ... & 717.14 & 716.36 & 714.78 & 715.70 & 714.17 \\
\hline 30 & -- & -- & 718.73 & 716.39 & -- & --- & -.. & 716.56 & 716.49 & 715.40 & 715.76 & 714.60 \\
\hline 31 & -.. &.-- & --- & 716.48 & $\cdots$ & -.. & $\cdots$ & $\cdots$ & 716.47 & --- & 715.55 & 714.59 \\
\hline Mean & 717.33 & 717.87 & 718.99 & 717.61 & 717.83 & 719.26 & 719.55 & 717.57 & 716.07 & 715.20 & 715.38 & 715.08 \\
\hline $\begin{array}{l}\text { Max- } \\
\text { imum }\end{array}$ & 717.55 & 718.80 & 719.13 & 719.53 & 719.22 & 719.37 & 719.69 & 719.32 & 716.57 & 716.49 & 716.41 & 716.04 \\
\hline $\begin{array}{l}\text { Mini- } \\
\text { mum }\end{array}$ & 717.00 & 717.14 & 718.73 & 716.22 & 716.40 & 719.15 & 719.42 & 716.56 & 715.51 & 714.38 & 713.90 & 713.92 \\
\hline
\end{tabular}


Table 10. Mean daily water levels in municipal well Seminole 10, February 1, 1993, through January 31, 1994

[Water levels given in feet above sea level; ---, no data]

\begin{tabular}{|c|c|c|c|c|c|c|c|c|c|c|c|c|}
\hline Day & Feb. & Mar. & Apr. & May & June & July & Aug. & Sept. & Oct. & Nov. & Dec. & Jan. \\
\hline 1 & $\ldots$ & $\cdots$ & -- & 702.35 & 704.16 & $\cdots$ & 710.31 & 711.40 & 705.74 & 704.37 & 704.05 & 701.27 \\
\hline 2 & $\ldots$ & $\cdots$ & $\cdots$ & 702.12 & 704.08 & 710.06 & 709.57 & 711.13 & 705.90 & 704.36 & 703.22 & 701.80 \\
\hline 3 & --- & 698.43 & $\ldots$ & 702.49 & 704.90 & 719.49 & 709.17 & 711.15 & 705.51 & 704.03 & 702.95 & 702.17 \\
\hline 4 & --- & 700.82 & $\cdots$ & 702.31 & 705.43 & 720.03 & 709.37 & 710.61 & 705.35 & 703.57 & 702.42 &.-- \\
\hline 5 & $\cdots$ & 701.79 & --- & 702.83 & 706.23 & 722.03 & 709.47 & 710.29 & 705.62 & 703.70 & 702.21 & 702.11 \\
\hline 6 & $\cdots$ & 701.89 & --- & 703.13 & 706.69 & 721.41 & 709.53 & 708.66 & 705.19 & 703.80 & 702.53 & 701.86 \\
\hline 7 & --- & 702.13 & $\cdots$ & 718.19 & 711.52 & 720.02 & 715.74 & 708.55 & 704.88 & 703.55 & 702.67 & 702.63 \\
\hline 8 & --- & 702.70 & --- & 722.10 & 716.53 & 719.71 & 720.12 & 708.86 & 704.74 & 703.73 & 704.36 & 701.27 \\
\hline 9 & --- & 702.85 & --- & 722.05 & 704.85 & 721.96 & 713.71 & 708.30 & 705.25 & 703.82 & 704.69 & 701.14 \\
\hline 10 & 715.73 & 703.05 & 703.55 & 721.74 & 705.62 & 723.89 & 716.20 & 708.24 & 705.77 & 703.65 & 715.52 & 700.87 \\
\hline 11 & 709.21 & 702.90 & 703.33 & 721.29 & 706.41 & 725.38 & 711.45 & 707.84 & 705.89 & 703.46 & 716.01 & 701.35 \\
\hline 12 & 699.76 & 701.67 & 703.82 & 718.18 & 717.59 & 726.11 & 712.82 & 707.19 & 705.78 & 703.23 & 715.45 & 701.14 \\
\hline 13 & 699.41 & 700.27 & 703.98 & 714.06 & 723.01 & 724.49 & 716.85 & 706.87 & 705.87 & 702.57 & 715.34 & 701.09 \\
\hline 14 & 699.46 & 699.81 & 703.66 & 705.59 & 722.29 & 723.87 & 711.73 & 708.99 & 705.63 & 702.54 & 715.42 & 701.48 \\
\hline 15 & 699.39 & 699.06 & 703.19 & 705.76 & 721.51 & 724.31 & 721.69 & 708.43 & 705.34 & 702.89 & 715.66 & 702.02 \\
\hline 16 & 699.18 & 698.68 & 703.26 & 705.87 & 712.83 & 724.27 & 715.55 & 709.19 & 705.06 & 703.24 & 715.87 & 701.18 \\
\hline 17 & 709.77 & 699.49 & 703.74 & 705.68 & 706.72 & 724.02 & 711.19 & 708.97 & 705.05 & 703.72 & 715.78 & --- \\
\hline 18 & 714.80 & 699.93 & 703.66 & 705.32 & 708.41 & 726.02 & 711.13 & 709.16 & 705.13 & 703.57 & 715.75 & -- \\
\hline 19 & 714.23 & 699.36 & 703.82 & 705.09 & 708.54 & 724.81 & 712.67 & 709.15 & 705.20 & 703.09 & 715.82 & $\cdots$ \\
\hline 20 & 714.11 & 699.03 & 703.85 & 704.73 & 709.52 & 717.80 & 715.14 & 708.82 & 704.94 & 703.20 & 715.79 & -- \\
\hline 21 & 696.82 & 698.82 & 703.74 & 704.49 & 709.38 & 713.79 & 715.65 & 707.70 & 705.10 & 703.04 & 706.36 & $\cdots$ \\
\hline 22 & 697.00 & 699.04 & 703.76 & 703.95 & 710.14 & 712.27 & 714.68 & 706.43 & 705.09 & 703.56 & 700.57 & 698.94 \\
\hline 23 & 697.61 & 699.78 & 703.29 & 703.49 & 710.89 & 711.73 & 713.75 & 706.45 & 704.80 & 703.35 & 701.39 & 698.63 \\
\hline 24 & 697.64 & 699.04 & 704.27 & 703.93 & 711.42 & 710.47 & 713.38 & 705.72 & 704.63 & 703.56 & 702.40 & 699.29 \\
\hline 25 & 697.31 & 699.74 & 705.72 & 704.16 & 711.16 & 709.43 & 713.06 & 705.23 & 704.55 & 703.33 & 700.87 & 699.96 \\
\hline 26 & 697.52 & 698.72 & 705.77 & 704.02 & 709.97 & 708.83 & 712.71 & 705.76 & 704.61 & 703.20 & 700.71 & 699.37 \\
\hline 27 & --- & -- & 704.38 & 703.88 & 708.81 & 708.46 & 712.97 & 705.78 & 704.54 & 703.02 & 702.16 & 698.96 \\
\hline 28 & --- & -- & 703.77 & 704.04 & 707.97 & 709.04 & 712.17 & 705.48 & 703.90 & 702.97 & 702.28 & 698.87 \\
\hline 29 & --- & --- & 703.08 & 704.24 & 707.32 & 709.70 & 711.83 & 705.45 & 704.26 & 703.15 & 702.09 & 699.17 \\
\hline 30 & --- & --- & 702.67 & 703.84 & --- & 709.47 & 711.13 & 705.44 & 704.33 & 703.61 & 701.95 & 699.57 \\
\hline 31 & --- & --- & --- & 704.08 & -- & 709.28 & 711.32 & --- & 704.32 & --- & 701.33 & 700.02 \\
\hline Mean & 703.47 & 700.37 & 703.82 & 707.58 & 710.13 & 717.74 & 713.10 & 708.04 & 705.10 & 703.43 & 707.21 & 700.65 \\
\hline $\begin{array}{l}\text { Max- } \\
\text { imum }\end{array}$ & 715.73 & 703.05 & 705.77 & 722.10 & 723.01 & 726.11 & 721.69 & 711.40 & 705.90 & 704.37 & 716.01 & 702.63 \\
\hline $\begin{array}{l}\text { Min- } \\
\text { imum }\end{array}$ & 696.82 & 698.43 & 702.67 & 702.12 & 704.08 & 708.46 & 709.17 & 705.23 & 703.90 & 702.54 & 700.57 & 698.63 \\
\hline
\end{tabular}


Tabie 11. Mean daily water levels in observation well CRM-3, February 1, 1993, through January 31, 1994

[Water levels given in feet above sea level: -..., no data]

\begin{tabular}{|c|c|c|c|c|c|c|c|c|c|c|c|c|}
\hline Day & Feb. & Mar. & Apr. & May & June & July & Aug. & Sept. & Oct. & Nov. & Dec. & Jan. \\
\hline 1 & -- & $\ldots$ & 724.21 & 719.11 & 717.33 & 720.35 & 721.16 & 721.06 & 716.55 & 715.58 & 715.74 & 715.82 \\
\hline 2 & $\cdots$ &.-- & 726.68 & 718.80 & 717.37 & 720.17 & 720.37 & 720.80 & 716.76 & 715.50 & 715.00 & 716.26 \\
\hline 3 & -- & 715.38 & 729.22 & 719.21 & 717.90 & 720.33 & 719.93 & 720.87 & 716.34 & 715.22 & 714.62 & 716.32 \\
\hline 4 & --- & 718.27 & 729.55 & 718.95 & 718.37 & 720.90 & 720.16 & 720.47 & 716.15 & 714.59 & 714.26 & $\ldots$ \\
\hline 5 & $\cdots$ & -- & 728.48 & 719.52 & 718.85 & 722.88 & 720.24 & 720.17 & 716.31 & 715.12 & 714.02 & 716.28 \\
\hline 6 & -- & -.- & 726.49 & 719.86 & 719.10 & 722.36 & 720.30 & 719.59 & 716.06 & 715.41 & 714.24 & 716.09 \\
\hline 7 & $\cdots$ & --- & 723.94 & 721.72 & 719.51 & 721.03 & 720.40 & 719.07 & 715.86 & 715.30 & 714.18 & 716.26 \\
\hline 8 & $\cdots$ & 721.00 & 722.02 & 722.62 & 720.17 & 720.66 & 720.12 & 718.61 & 715.64 & 715.43 & 714.35 & 716.12 \\
\hline 9 & -- & 720.49 & -.- & 722.61 & 719.94 & 722.79 & 719.15 & 717.95 & 716.10 & 715.45 & 714.00 & 716.05 \\
\hline 10 & 716.51 & 719.39 & 720.88 & 722.26 & 720.82 & 724.70 & 721.94 & 717.84 & 716.80 & 715.19 & 715.19 & 715.78 \\
\hline 11 & 716.33 & 719.49 & 720.59 & 721.85 & 721.88 & 726.24 & 720.35 & 717.33 & 716.91 & 714.83 & 715.64 & 715.91 \\
\hline 12 & 715.07 & 718.30 & 721.00 & 721.15 & 723.71 & 727.00 & 719.49 & 716.74 & 716.81 & 714.68 & 715.15 & 715.66 \\
\hline 13 & 714.93 & 716.72 & 720.96 & 720.73 & 724.03 & 725.39 & 719.84 & 716.73 & 716.68 & 714.38 & 715.03 & 715.56 \\
\hline 14 & 714.99 & 716.19 & 720.51 & 719.92 & 723.53 & 724.68 & 719.82 & 717.27 & 716.27 & 714.66 & 715.15 & 715.67 \\
\hline 15 & 714.89 & 715.47 & 719.94 & 720.22 & 722.94 & 725.18 & 721.59 & 717.73 & 716.08 & 715.03 & 715.31 & 715.82 \\
\hline 16 & 714.75 & 715.20 & 719.98 & 720.21 & 721.44 & -- & 721.55 & 717.78 & 715.90 & 715.08 & 715.50 & 715.33 \\
\hline 17 & 715.72 & 716.28 & 720.31 & 719.61 & 720.49 & 724.81 & 721.97 & 717.72 & 715.88 & 715.14 & 715.43 & 715.33 \\
\hline 18 & 716.18 & --- & 720.24 & 719.01 & 720.63 & 726.86 & 721.48 & 717.91 & 715.99 & 714.80 & -- & 715.45 \\
\hline 19 & 716.15 & -- & 720.27 & 718.74 & 720.97 & 725.66 & 723.08 & 717.93 & 716.02 & 714.49 & 715.46 & 715.29 \\
\hline 20 & 716.02 & 715.91 & 721.56 & 718.35 & 722.21 & 724.27 & 725.40 & 717.58 & 715.83 & 714.57 & 715.33 & 715.43 \\
\hline 21 & 714.18 & 715.68 & 721.91 & 718.07 & 722.08 & 724.21 & 726.47 & 717.48 & 715.96 & 714.37 & 714.76 & -- \\
\hline 22 & 714.50 & 715.69 & 721.47 & 717.68 & 722.96 & 724.28 & 725.13 & 717.17 & 716.00 & 714.57 & 714.27 & 714.65 \\
\hline 23 & 714.80 & 716.61 & 721.33 & 717.27 & 723.91 & 723.53 & 724.02 & 717.19 & 715.73 & 714.49 & 715.07 & 714.46 \\
\hline 24 & 714.79 & 715.86 & 722.34 & 717.38 & 724.50 & 722.38 & 723.55 & 717.11 & 715.47 & 714.76 & 716.11 & 714.54 \\
\hline 25 & 714.42 & $\cdots$ & 724.03 & 717.56 & 724.18 & 721.18 & 723.13 & 717.01 & 715.39 & 714.77 & 715.86 & 714.62 \\
\hline 26 & 714.70 & --- & 723.88 & 717.39 & 722.84 & 720.39 & 722.71 & 717.42 & 715.50 & 714.63 & 715.58 & 714.61 \\
\hline 27 & $\cdots$ & 718.15 & 722.29 & 717.17 & 721.45 & 719.63 & 723.02 & 717.50 & 715.59 & 714.37 & 715.98 & 714.18 \\
\hline 28 & -.. & 718.65 & 721.16 & 717.40 & 720.37 & 719.84 & 722.13 & 717.48 & 715.05 & 714.36 & 716.11 & 714.23 \\
\hline 29 & -- & 719.43 & 720.26 & 717.70 & 719.71 & 720.28 & 721.71 & 717.50 & 715.44 & 714.60 & 715.98 & 714.45 \\
\hline 30 & $\cdots$ & 720.56 & 719.57 & 717.32 & 720.19 & 720.24 & 721.07 & 716.99 & 715.57 & 715.17 & 716.04 & 714.89 \\
\hline 31 & -- & 722.21 & -- & 717.38 & $\cdots$ & 720.18 & 721.11 & -- & 715.55 & --- & 715.86 & 714.84 \\
\hline Mean & 715.23 & 717.77 & 722.59 & 719.25 & 721.11 & 722.75 & 721.69 & 718.13 & 716.01 & 714.88 & 715.17 & 715.38 \\
\hline $\begin{array}{l}\text { Max- } \\
\text { imum }\end{array}$ & 716.51 & 722.21 & 729.55 & 722.62 & 724.50 & 727.00 & 726.47 & 721.06 & 716.91 & 715.58 & 716.11 & 716.32 \\
\hline $\begin{array}{l}\text { Min- } \\
\text { imum }\end{array}$ & 714.18 & 715.20 & 719.57 & 717.17 & 717.33 & 719.63 & 719.15 & 716.73 & 715.05 & 714.36 & 714.00 & 714.18 \\
\hline
\end{tabular}


Table 12. Water-level measurements for observation wells CRM-3, CRM-4, and CRM-6, February 1993 through January 1994

[Water-level measurements, in feet above sea level, made using a steel tape and measured to $0.01 \mathrm{ft}$ :---, no data]

\begin{tabular}{|c|c|c|c|c|c|c|}
\hline \multirow{2}{*}{$\begin{array}{c}\text { Date } \\
\text { (month-day- } \\
\text { year) }\end{array}$} & \multicolumn{2}{|c|}{ Observation well CRM-3 } & \multicolumn{2}{|c|}{ Observation well CRM-4 } & \multicolumn{2}{|c|}{ Observation well CRM-6 } \\
\hline & $\begin{array}{c}\text { Time } \\
\text { (24-hour) }\end{array}$ & $\begin{array}{l}\text { Water } \\
\text { level }\end{array}$ & $\begin{array}{c}\text { Time } \\
\text { (24-hour) }\end{array}$ & $\begin{array}{l}\text { Water } \\
\text { level }\end{array}$ & $\begin{array}{c}\text { Time } \\
\text { (24-hour }\end{array}$ & $\begin{array}{l}\text { Water } \\
\text { level }\end{array}$ \\
\hline $02-04-93$ & $\cdots$ & $\cdots$ & 1510 & 717.46 & -- & --- \\
\hline $02-09-93^{l}$ & 1350 & 717.49 & 1100 & 716.80 & $\cdots$ & $\cdots$ \\
\hline $02-11-93$ & -- & $-\cdots$ & 1455 & 716.11 & $-\cdots$ & $\cdots$ \\
\hline $02-18-93^{!}$ & 1425 & 716.36 & 1310 & 716.93 & -- & -- \\
\hline $03-02-93$ & 1510 & 714.73 & 1310 & 714.54 & -- & --- \\
\hline $03-18-93$ & 1255 & 716.43 & 1135 & 716.31 & -- & $\cdots$ \\
\hline $03-25-93$ & 1145 & 717.35 & 0855 & 717.24 & -- & --- \\
\hline $04-09-93$ & 1530 & 722.14 & 1522 & 721.46 & $\cdots$ & $\ldots$ \\
\hline 04-23-93 & 1415 & 722.30 & 1235 & 721.67 & $\cdots$ & -.- \\
\hline $06-03-93$ & 1350 & 718.53 & 1140 & 718.09 & $\cdots$ & --- \\
\hline $06 \cdot 16-93$ & 1220 & 721.33 & 1115 & 721.00 & --- & --- \\
\hline $07-01-93$ & 1310 & 720.98 & 1115 & 720.70 & --- & -- \\
\hline $08-24-93$ & 1135 & 724.47 & 0915 & 724.22 & --- & --- \\
\hline $09-10-93$ & 1120 & 718.80 & 0905 & 718.57 & --- & --- \\
\hline $10-12-93$ & $\ldots$ & $\ldots$ & 0850 & 717.19 & -.. & --- \\
\hline $10-13-93$ & 1215 & 717.40 & 1015 & 716.95 & --- & $\cdots$ \\
\hline $10-28-93$ & 1145 & 716.47 & 0955 & 716.04 & --- & -.. \\
\hline $11-04-93$ & 1230 & 716.21 & 1200 & 715.86 & 0856 & 720.78 \\
\hline $11-09-93$ & 1235 & 716.00 & 1025 & 715.58 & -.. & --- \\
\hline $11-23-93$ & 1130 & 715.59 & 0950 & 715.35 & $\ldots$ & --- \\
\hline $12-06-93$ & 1305 & 715.17 & 1025 & 714.88 & -- & -- \\
\hline $12-20-93^{1}$ & 1200 & 716.62 & 1100 & 717.12 & 0930 & 721.06 \\
\hline $01-04-94$ & 1145 & 717.06 & 1045 & 716.69 & -.. & -.- \\
\hline $01-21-94$ & 1400 & 715.26 & 1330 & 714.86 & $\cdots$ & -- \\
\hline $02-19-94$ & 0830 & 715.60 & 0830 & 715.47 & 0830 & 719.92 \\
\hline
\end{tabular}

${ }^{1}$ Municipal well Seminole 10 was not operating on this day. 
Table 13. Mean daily specific conductance of water from the Cedar River, surface-water monitoring site, February 1, 1993, through January 31, 1994

[Specific conductance given in microsiemens per centimeter at 25 degrees Celsius; ---, no data]

\begin{tabular}{|c|c|c|c|c|c|c|c|c|c|c|c|c|}
\hline Day & Feb. & Mar. & Apr. & May & June & July & Aug. & Sept. & Oct. & Nov. & Dec. & Jan. \\
\hline 1 & 640 & 636 & 251 & 467 & 555 & 434 & 397 & 433 & 565 & 541 & 576 & 628 \\
\hline 2 & 631 & 627 & 237 & 468 & 555 & 438 & 436 & 440 & 565 & 543 & 578 & 632 \\
\hline 3 & 635 & 408 & 229 & 432 & 533 & 411 & 454 & 473 & 562 & 547 & 583 & 627 \\
\hline 4 & 625 & 237 & 237 & 452 & 506 & 409 & 445 & 487 & 554 & 554 & 586 & 620 \\
\hline 5 & 594 & 223 & 262 & 452 & 508 & 380 & 434 & 502 & 536 & 559 & 589 & 610 \\
\hline 6 & 595 & 238 & 310 & 450 & 516 & 411 & 437 & 521 & 525 & 562 & 588 & 600 \\
\hline 7 & 596 & 260 & 368 & 408 & 521 & 464 & 480 & 535 & 517 & 563 & 582 & 600 \\
\hline 8 & 595 & 274 & 414 & 411 & 491 & 477 & 518 & 541 & 507 & 567 & 582 & 604 \\
\hline 9 & 592 & 281 & --- & 433 & 454 & 358 & 527 & 544 & 499 & 565 & 580 & 609 \\
\hline 10 & 571 & 283 & 434 & 446 & 416 & 273 & 348 & 540 & 479 & 562 & 576 & 616 \\
\hline 11 & 500 & 280 & 446 & 456 & 389 & 249 & 408 & 535 & 482 & 561 & 571 & 615 \\
\hline 12 & 553 & 290 & 455 & 465 & 405 & 262 & 488 & 539 & 505 & 561 & 572 & 607 \\
\hline 13 & 576 & 369 & 458 & 462 & 430 & 314 & 481 & 540 & 514 & 560 & 573 & 603 \\
\hline 14 & 583 & 406 & 464 & 450 & 460 & 331 & 411 & 523 & 519 & 559 & 570 & 604 \\
\hline 15 & --- & 437 & 472 & 448 & 478 & 342 & 379 & 502 & 525 & 553 & 567 & 604 \\
\hline 16 & --- & 486 & 471 & 459 & 483 & 367 & 391 & 503 & 533 & 554 & 573 & 603 \\
\hline 17 & --- & 454 & 468 & 471 & 482 & 392 & 370 & 517 & 538 & 556 & 572 & 606 \\
\hline 18 & --- & 403 & 471 & --- & 481 & 355 & 404 & 500 & 542 & 561 & --- & 611 \\
\hline 19 & --- & --- & 462 & --- & 442 & 372 & 337 & 473 & 543 & 562 & 567 & 614 \\
\hline 20 & $\ldots$ & 366 & 437 & --- & 388 & 388 & 286 & 486 & 550 & 563 & 561 & 614 \\
\hline 21 & $-\cdots$ & 433 & 446 & 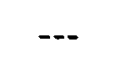 & 402 & 380 & 314 & 499 & 549 & 563 & 554 & 616 \\
\hline 22 & --. & 443 & 447 & 549 & 385 & 396 & 365 & 512 & 545 & 563 & 556 & 609 \\
\hline 23 & --- & 343 & 436 & 553 & 376 & 424 & 384 & 526 & 540 & 569 & 568 & 603 \\
\hline 24 & ... & 401 & 400 & 557 & 387 & 466 & 397 & 544 & 536 & 575 & 589 & 597 \\
\hline 25 & ... & 323 & 380 & 559 & 415 & 500 & 421 & 549 & 527 & 574 & 600 & 593 \\
\hline 26 & -.. & 285 & 408 & 563 & 461 & 519 & 401 & 528 & 523 & 573 & 609 & 591 \\
\hline 27 & 636 & 283 & 451 & 560 & 497 & 526 & 408 & 529 & 527 & 572 & 612 & 590 \\
\hline 28 & 638 & 261 & 479 & 553 & 518 & 496 & 452 & 539 & 526 & 569 & 619 & 591 \\
\hline 29 & -.- & 238 & 496 & 537 & 530 & 458 & 450 & 556 & 532 & 569 & 619 & 591 \\
\hline 30 & --- & 227 & 487 & 545 & 460 & 462 & 454 & 563 & 536 & 575 & 625 & 585 \\
\hline 31 & --- & 240 & $\cdots$ & 550 & $\cdots$ & 476 & 435 & $\cdots$ & 539 & --- & 626 & 586 \\
\hline Mean & 597 & 348 & 406 & 487 & 464 & 404 & 417 & 516 & 530 & 562 & 584 & 606 \\
\hline $\begin{array}{l}\text { Maxi- } \\
\text { mum }\end{array}$ & 640 & 636 & 496 & 563 & 555 & 526 & 527 & 563 & 565 & 575 & 626 & 632 \\
\hline $\begin{array}{l}\text { Mini- } \\
\text { mumn }\end{array}$ & 500 & 223 & 229 & 408 & 376 & 249 & 286 & 433 & 479 & 541 & 554 & 585 \\
\hline
\end{tabular}


Table 14. Mean daily specific conductance of water from observation well CRM-4, February 1, 1993, through January 31, 1994

[Specific conductance given in microsiemens per centimeter at 25 degrees Celsius; ---, no data]

\begin{tabular}{|c|c|c|c|c|c|c|c|c|c|c|c|c|}
\hline Day & Feb. & Mar. & Apr. & May & June & July & Aug. & Sept. & Oct. & Nov. & Dec. & Jan. \\
\hline 1 & 581 & -.. & 332 & 453 & 530 & 511 & 443 & 444 & 524 & 546 & 560 & 626 \\
\hline 2 & 581 & -.- & 312 & 469 & 532 & 523 & 466 & 447 & 524 & 543 & 557 & 631 \\
\hline 3 & 585 & 644 & 300 & 480 & 538 & -.. & 414 & 449 & 537 & 541 & 558 & 632 \\
\hline 4 & 594 & 645 & 287 & 485 & 546 & --- & 405 & 445 & 549 & 543 & 563 & --- \\
\hline 5 & 604 & 624 & 283 & 477 & 548 & --- & 439 & 437 & 554 & 544 & 566 & 630 \\
\hline 6 & 612 & 464 & 283 & 460 & 536 & -.- & 439 & 436 & 556 & 544 & 554 & 634 \\
\hline 7 & 618 & 330 & 285 & 472 & 516 & $\cdots$ & 435 & 457 & 556 & 549 & 548 & 634 \\
\hline 8 & 623 & 291 & 293 & 474 & 507 & --- & 436 & 477 & 550 & 556 & 552 & 628 \\
\hline 9 & --- & 275 & -- & 476 & 510 & -- & 437 & 496 & 538 & 558 & 555 & 616 \\
\hline 10 & 625 & 272 & 294 & 479 & 516 & --- & 429 & 513 & --- & 558 & 556 & 608 \\
\hline 11 & 628 & 279 & 321 & 477 & 493 & -- & 430 & 525 & --. & 558 & 555 & 607 \\
\hline 12 & 628 & 286 & 388 & 476 & 470 & -- & 480 & 530 &.-- & 560 & 557 & 609 \\
\hline 13 & 618 & 292 & 450 & 476 & 467 & -- & 490 & 532 & --. & 562 & 557 & 613 \\
\hline 14. & 582 & 303 & 478 & 479 & 462 & -- & 379 & 532 & 485 & 563 & 557 & 619 \\
\hline 15 & 539 & 314 & 488 & 475 & 458 & 518 & 373 & 532 & 481 & 565 & 557 & 623 \\
\hline 16 & 560 & 330 & 488 & 478 & 450 & 510 & 387 & 533 & 493 & 566 & 557 & 618 \\
\hline 17 & 574 & 363 & --- & 471 & 421 & 504 & 431 & 536 & 512 & 566 & 557 & 614 \\
\hline 18 & 584 & 415 & -.. & 482 & 406 & 503 & 432 & 525 & 523 & 565 & 565 & --- \\
\hline 19 & 593 & 446 & --- & 505 & 445 & 503 & 388 & 508 & 531 & 560 & 571 & $\cdots$ \\
\hline 20 & 590 & 479 & -.- & 516 & 478 & 493 & 361 & 504 & 539 & 561 & 571 & --- \\
\hline 21 & 596 & 497 & --- & 526 & 478 & 442 & 387 & 508 & 545 & 562 & 570 & $\cdots$ \\
\hline 22 & 611 & 469 & --- & 534 & 471 & 438 & 387 & 502 & 549 & 565 & 571 & 624 \\
\hline 23 & 627 & 408 & $\ldots$ & 539 & 439 & 429 & 345 & 480 & 551 & 566 & 576 & 627 \\
\hline 24 & 655 & 391 & 467 & 542 & 413 & 390 & 315 & 495 & 556 & 568 & 575 & 628 \\
\hline 25 & 658 & 418 & 466 & 544 & 411 & 392 & 323 & 513 & 553 & 567 & 568 & 628 \\
\hline 26 & 654 & 452 & 453 & 543 & 403 & 409 & 355 & 531 & 546 & 567 & 570 & 623 \\
\hline 27 & 651 & 415 & 426 & 543 & 395 & 453 & 380 & 541 & 540 & 565 & 576 & 617 \\
\hline 28 & --- & 415 & 404 & 543 & 404 & 493 & 394 & 538 & 546 & 565 & 590 & 612 \\
\hline 29 & --- & 381 & 417 & 546 & 439 & 502 & 415 & 526 & 550 & 566 & 604 & 609 \\
\hline 30 & --- & 351 & 438 & 545 & 486 & 478 & 412 & 524 & 549 & 565 & 611 & 608 \\
\hline 31 & --- & 342 & -.. & 542 & $\cdots$ & 447 & 410 & $\cdots$ & 550 & $\cdots$ & 619 & 606 \\
\hline Mean & 607 & 400 & 380 & 500 & 472 & 470 & 407 & 501 & 537 & 559 & 568 & 620 \\
\hline $\begin{array}{l}\text { Max- } \\
\text { imum }\end{array}$ & 658 & 645 & 488 & 546 & 548 & 523 & 490 & 541 & 556 & 568 & 619 & 634 \\
\hline $\begin{array}{l}\text { Min- } \\
\text { mum }\end{array}$ & 539 & 272 & 283 & 453 & 395 & 390 & 315 & 436 & 481 & 541 & 548 & 606 \\
\hline
\end{tabular}


Table 15. Mean daily specific conductance of water from municipal well Seminole 10, February 1, 1993, through January 31, 1994

[Specific conductance given in microsiemens per centimeter at 25 degrees Celsius; -.., no data]

\begin{tabular}{|c|c|c|c|c|c|c|c|c|c|c|c|c|}
\hline Day & Feb. & Mar. & Apr. & May & June & July & Aug. & Sept. & Oct. & Nov. & Dec. & Jan. \\
\hline 1 & 538 & -.- & --- & 386 & 550 & --- & 447 & 432 & 537 & 537 & 574 & 575 \\
\hline 2 & 539 & $\ldots$ & --- & 381 & 550 & 418 & 453 & 428 & 535 & 536 & 573 & 583 \\
\hline 3 & 539 & 636 & -- & 388 & 547 & 461 & 461 & 427 & 534 & 535 & 573 & 593 \\
\hline 4 & 541 & 635 & -- & 402 & 546 & 460 & 470 & 429 & 536 & 534 & 572 & $\ldots$ \\
\hline 5 & 542 & 634 & --- & 416 & 544 & 464 & 475 & 428 & 541 & 533 & 571 & 617 \\
\hline 6 & 542 & 634 & -- & 430 & 541 & 443 & 459 & 415 & 548 & 532 & 562 & 623 \\
\hline 7 & 541 & 635 & -- & 414 & 533 & 447 & 440 & 417 & 553 & 531 & 556 & 628 \\
\hline 8 & --- & 626 & '-. & 404 & 522 & 467 & 431 & 422 & 556 & 530 & 557 & 632 \\
\hline 9 & --- & 596 &.-- & 395 & 541 & 473 & 438 & 425 & 557 & 527 & 558 & 636 \\
\hline 10 & 575 & 571 & 287 & 393 & 538 & 470 & 442 & 416 & 555 & 525 & 553 & 638 \\
\hline 11 & 587 & 520 & 288 & 405 & 531 & 466 & 447 & 413 & 549 & 528 & 552 & 640 \\
\hline 12 & 608 & 445 & 290 & 405 & 515 & 468 & 436 & 419 & 535 & 533 & 550 & 640 \\
\hline 13 & 627 & 383 & 299 & 422 & 517 & 468 & 437 & 425 & 526 & 534 & 550 & 637 \\
\hline 14 & 634 & 348 & 321 & 448 & 517 & 465 & 434 & 433 & 520 & 537 & 548 & 633 \\
\hline 15 & 635 & 325 & 355 & 453 & 522 & 458 & 427 & 436 & 512 & 542 & 547 & 628 \\
\hline 16 & 630 & 310 & 390 & 453 & 521 & 468 & 429 & 446 & 501 & 546 & 547 & 625 \\
\hline 17 & 615 & 305 & 423 & 451 & 516 & 478 & 431 & 459 & 493 & 548 & 547 & --- \\
\hline 18 & 609 & 306 & 450 & 478 & 509 & 476 & 431 & 468 & 492 & 550 & 546 & -- \\
\hline 19 & 610 & 313 & 470 & 505 & 500 & 480 & 428 & 477 & 498 & 551 & 546 & --- \\
\hline 20 & 609 & 326 & 487 & 505 & 488 & 458 & 427 & 485 & 506 & 551 & 546 & --- \\
\hline 21 & 627 & 349 & 495 & 505 & 473 & 438 & 425 & 495 & 515 & 551 & 551 & --- \\
\hline 22 & 600 & 381 & 500 & 507 & 454 & 435 & 426 & 496 & 522 & 551 & 558 & 586 \\
\hline 23 & 590 & 417 & 506 & 510 & 449 & 441 & 426 & 491 & 530 & 562 & 566 & 585 \\
\hline 24 & 595 & 453 & 510 & 514 & 449 & 449 & 444 & 510 & 535 & 570 & 570 & 585 \\
\hline 25 & 606 & 469 & 508 & 522 & 454 & 455 & 459 & 517 & 539 & 570 & 571 & 585 \\
\hline 26 & 619 & 463 & 499 & 531 & 459 & 456 & 456 & 515 & 542 & 572 & 571 & 587 \\
\hline 27 & $\ldots$ & -- & 492 & 538 & 460 & 453 & 451 & 518 & 544 & 574 & 572 & 589 \\
\hline 28 & -. & -- & 486 & 545 & 453 & 446 & 449 & 525 & 546 & 575 & 572 & 591 \\
\hline 29 & -- & --- & 477 & 547 & 443 & 439 & 444 & 534 & 546 & 574 & 571 & 592 \\
\hline 30 &.- & --- & 429 & 550 & -.. & 439 & 441 & 538 & 544 & 574 & 570 & 592 \\
\hline 31 & $\cdots$ & -- & $\ldots$ & 550 & -.- & 443 & 438 & $\cdots$ & 540 & --- & 571 & 591 \\
\hline Mean & 590 & 462 & 427 & 463 & 505 & 456 & 442 & 461 & 532 & 547 & 560 & 608 \\
\hline $\begin{array}{l}\text { Max- } \\
\text { imum }\end{array}$ & 635 & 636 & 510 & 550 & 550 & 480 & 475 & 538 & 557 & 575 & 574 & 640 \\
\hline $\begin{array}{l}\text { Min- } \\
\text { imum }\end{array}$ & 538 & 305 & 287 & 381 & 443 & 418 & 425 & 413 & 492 & 525 & 546 & 575 \\
\hline
\end{tabular}


Table 16. Mean daily specific conductance for water from observation well CRM-3, February 1, 1993, through January 31, 1994

[Specific conductance given in microsiemens per centimeter at 25 degrees Celsius; -... no data]

\begin{tabular}{|c|c|c|c|c|c|c|c|c|c|c|c|c|}
\hline Day & Feb. & Mar. & Apr. & May & June & July & Aug. & Sept. & Oct. & Nov. & Dec. & Jan. \\
\hline 1 & --- & -- & 513 & 462 & 474 & 441 & 579 & 647 & 585 & 523 & 548 & 592 \\
\hline 2 & -.- & --. & 513 & 460 & 472 & 445 & 575 & 674 & 587 & 519 & 545 & 581 \\
\hline 3 & --- & 610 & 528 & 461 & 474 & 457 & 565 & 687 & 588 & 515 & 540 & 580 \\
\hline 4 & --- & 613 & 566 & 458 & 476 & 473 & 557 & 675 & 587 & 515 & 550 & --- \\
\hline 5 & -.- & $\ldots$ & 616 & 455 & 473 & 484 & 548 & 665 & 579 & 518 & 553 & 544 \\
\hline 6 & --- & --- & 623 & 452 & 466 & 483 & 533 & 640 & 565 & 514 & 554 & 549 \\
\hline 7 & --- & --- & 626 & 451 & 462 & 471 & 515 & 617 & 558 & 512 & 556 & 553 \\
\hline 8 & -.. & 605 & 630 & 447 & 465 & 465 & 515 & 633 & 561 & 510 & 552 & 556 \\
\hline 9 &.- & 605 & $\ldots$ & 444 & 465 & 477 & 499 & 533 & 573 & 511 & 553 & 557 \\
\hline 10 & 604 & 608 & 614 & $45 !$ & 459 & 494 & 492 & -.. & 583 & 512 & 552 & 559 \\
\hline 11 & 598 & 604 & 622 & 453 & 458 & 506 & 492 & 476 & 591 & 512 & 579 & 559 \\
\hline 12 & 588 & 597 & 634 & 443 & 461 & 515 & 498 & 485 & 592 & 513 & 587 & 560 \\
\hline 13 & 608 & 598 & 643 & 435 & 462 & 508 & 509 & 497 & 593 & 514 & 582 & 560 \\
\hline 14 & 624 & 600 & 649 & 426 & 459 & 507 & 470 & 509 & 593 & 515 & 587 & 559 \\
\hline 15 & 637 & 598 & 650 & 455 & 463 & 508 & 472 & 505 & 595 & 515 & 586 & 559 \\
\hline 16 & 648 & 600 & 640 & 470 & 464 & -. & 490 & 507 & 594 & 515 & 575 & 558 \\
\hline 17 & 655 & 604 & 625 & 469 & 456 & 523 & 511 & 511 & 585 & 514 & 561 & 558 \\
\hline 18 & 647 & --- & 629 & 475 & 444 & 526 & 520 & 508 & 598 & 516 & -.- & 557 \\
\hline 19 & 622 & -- & 640 & 468 & 443 & 530 & 517 & 496 & 620 & 515 & 568 & 556 \\
\hline 20 & 628 & 609 & 641 & 480 & 445 & 504 & 517 & 492 & 630 & 515 & 575 & 556 \\
\hline 21 & 633 & 614 & 638 & 512 & 448 & 492 & 530 & 505 & 642 & 516 & 577 & --- \\
\hline 22 & 627 & 601 & 638 & 516 & 451 & 524 & 528 & 514 & 651 & 519 & 561 & 564 \\
\hline 23 & 628 & 602 & 621 & 515 & 444 & 535 & 515 & 516 & 634 & 521 & 564 & 565 \\
\hline 24 & 629 & 606 & 589 & 516 & 439 & 539 & 509 & 524 & 618 & 523 & 579 & 567 \\
\hline 25 & 609 & --- & 575 & 510 & 446 & 535 & 501 & 519 & 596 & 524 & 584 & 567 \\
\hline 26 & 603 & $\cdots$ & 546 & 503 & 452 & 505 & 505 & 514 & 577 & 524 & 596 & 568 \\
\hline 27 & -- & 624 & 524 & 498 & 456 & 501 & 546 & 520 & 564 & 526 & 631 & 569 \\
\hline 28 & --- & 611 & 507 & 490 & 458 & 502 & 597 & 536 & 554 & 527 & 602 & 572 \\
\hline 29 & -- & 592 & 486 & 484 & 458 & 513 & 594 & 565 & 541 & 530 & 590 & 575 \\
\hline 30 & --- & 572 & 471 & 480 & 446 & 542 & 600 & 588 & 535 & 537 & 600 & 577 \\
\hline 31 & -.- & 559 & -.- & 478 & --- & 563 & 629 & --- & 529 & --. & 596 & 581 \\
\hline Mean & 623 & 601 & 593 & 472 & 458 & 502 & 530 & 554 & 587 & 518 & 573 & 564 \\
\hline $\begin{array}{l}\text { Max- } \\
\text { imum }\end{array}$ & 655 & 624 & 650 & 516 & 476 & 563 & 629 & 687 & 651 & 537 & 631 & 592 \\
\hline $\begin{array}{l}\text { Min- } \\
\text { imum }\end{array}$ & 588 & 559 & 471 & 426 & 439 & 441 & 470 & 476 & 529 & 510 & 540 & 544 \\
\hline
\end{tabular}


Table 17. Mean daily specific conductance of water from the Cedar Rapids municipal water-treatment plant, February 1, 1993, through January 31, 1994

[Specific conductance given in microsiemens per centimeter at 25 degrees Celsius; --., no data]

\begin{tabular}{|c|c|c|c|c|c|c|c|c|c|c|c|c|}
\hline Day & Feb. & Mar. & Apr. & May & June & July & Aug. & Sept. & Oct. & Nov. & Dec. & Jan. \\
\hline 1 & -.- & 590 & 522 & 471 & 505 & 473 & -.. & 443 & 487 & 509 & 517 & $\cdots$ \\
\hline 2 & -.. & 602 & 512 & 477 & 502 & 464 & ... & 445 & 488 & 504 & 516 & -.. \\
\hline 3 & --- & 594 & 516 & 473 & 494 & 466 & -.. & 451 & 499 & 501 & 516 & -.- \\
\hline 4 & -.- & 585 & 530 & 492 & 496 & 462 & -.- & 439 & 488 & 503 & 517 & --. \\
\hline 5 & -.- & 584 & 499 & 486 & 500 & 464 & --- & 443 & 488 & 501 & 520 & 551 \\
\hline 6 & --- & 585 & 503 & 471 & 505 & 462 & -.. & 442 & 489 & 506 & --- & 548 \\
\hline 7 & --. & 582 & --. & 464 & 506 & 459 & 422 & 447 & 483 & 496 & 543 & 543 \\
\hline 8 & --.- & 586 & --. & 468 & 503 & --- & 425 & 448 & 482 & 506 & 544 & 531 \\
\hline 9 & --- & 586 & -.. & 467 & 500 & --. & 419 & 448 & 481 & 513 & 544 & 528 \\
\hline 10 & -.. & ... & 476 & 467 & 502 & --. & 424 & 449 & 480 & 525 & 540 & 525 \\
\hline 11 & --- & 564 & 489 & 460 & 500 & --- & 430 & 465 & 486 & 520 & 531 & 527 \\
\hline 12 & --- & 576 & 498 & 475 & 500 & -..- & 424 & 475 & 478 & 522 & 528 & 520 \\
\hline 13 & ... & 575 & 486 & 491 & 499 & --- & 424 & 471 & 478 & 518 & 525 & 527 \\
\hline 14 & $\ldots$ & 565 & 489 & 487 & 495 & ... & 430 & 478 & 478 & 517 & 522 & 521 \\
\hline 15 & -.. & 571 & 491 & 479 & 493 & --. & 420 & 492 & 473 & 517 & 521 & 523 \\
\hline 16 & --- & 564 & 492 & 470 & 490 & --. & 421 & 479 & 484 & 518 & 520 & 528 \\
\hline 17 & 588 & 544 & 496 & 473 & 492 & -.. & 424 & 486 & 476 & 500 & 518 & 529 \\
\hline 18 & 588 & 578 & 498 & 474 & 507 & --. & 425 & 489 & 479 & 498 & -.. & 525 \\
\hline 19 & 581 & 584 & 508 & 477 & 500 & --- & 420 & 486 & 477 & 513 & 540 & 521 \\
\hline 20 & 585 & 573 & 507 & 480 & 494 & ... & 418 & 485 & 474 & 513 & 538 & 526 \\
\hline 21 & 586 & 576 & 507 & 481 & 490 & -.. & 423 & 486 & 472 & 513 & 536 & ... \\
\hline 22 & 581 & 563 & 509 & 483 & 491 & -.. & 431 & 483 & 479 & 511 & 536 & 514 \\
\hline 23 & 567 & 569 & 492 & 491 & 502 & --. & 431 & 481 & 477 & 517 & 534 & 509 \\
\hline 24 & 580 & 557 & 494 & 499 & 497 & -..- & 440 & 490 & 471 & 525 & 535 & 514 \\
\hline 25 & 566 & --. & 490 & 497 & 487 & --. & 453 & 492 & 474 & 524 & 536 & 511 \\
\hline 26 & --. & 563 & 483 & 496 & 483 & $\cdots$ & 453 & 486 & 475 & 520 & -.. & 523 \\
\hline 27 & 563 & 549 & 466 & 502 & 475 & --- & 441 & 483 & 476 & 522 & $\cdots$ & 516 \\
\hline 28 & 581 & 530 & 465 & 508 & 468 & --- & 443 & 484 & 493 & 522 & --. & 519 \\
\hline 29 & -.. & 518 & 466 & 513 & 474 & --- & 438 & 488 & 513 & 519 & -.. & 519 \\
\hline 30 & $\ldots$ & 513 & 474 & 510 & 473 & --- & 436 & 485 & 509 & 512 & --- & 504 \\
\hline 31 & -- & 511 & --- & 506 & --- & --- & 441 & $\cdots$ & 507 & $\cdots$ & --- & 519 \\
\hline Mean & 579 & 567 & 495 & 483 & 494 & 464 & 430 & 471 & 484 & 513 & 529 & 524 \\
\hline $\begin{array}{l}\text { Max- } \\
\text { imum }\end{array}$ & 588 & 602 & 530 & 513 & 507 & 473 & 453 & 492 & 513 & 525 & 544 & 551 \\
\hline $\begin{array}{l}\text { Min- } \\
\text { imum }\end{array}$ & 563 & 511 & 465 & 460 & 468 & 459 & 418 & 439 & 471 & 496 & 516 & 504 \\
\hline
\end{tabular}


Table 18. Mean daily pH of water from the Cedar River, surface-water monitoring site, February 1, 1993, through January 31, 1994

[pH given in standard units; ---, no data]

\begin{tabular}{|c|c|c|c|c|c|c|c|c|c|c|c|c|}
\hline Day & Feb. & Mar. & Apr. & May & June & July & Aug. & Sept. & Oct. & Nov. & Dec. & Jan. \\
\hline 1 & 7.9 & 7.8 & 7.4 & 8.1 & 8.5 & 7.9 & 8.0 & 8.2 & 8.2 & 8.4 & 8.2 & 7.8 \\
\hline 2 & 7.9 & 7.8 & 7.4 & 8.1 & 8.5 & 8.0 & 8.1 & 8.2 & 8.3 & 8.4 & 8.2 & 7.8 \\
\hline 3 & 8.0 & 7.8 & 7.5 & 8.0 & 8.3 & 8.0 & 8.1 & 8.3 & 8.4 & 8.4 & 8.2 & 7.8 \\
\hline 4 & 7.9 & 7.6 & 7.5 & 8.0 & 8.2 & 8.0 & 8.2 & 8.3 & 8.4 & 8.4 & 8.2 & 7.8 \\
\hline 5 & 7.8 & 7.5 & 7.5 & 8.0 & 8.2 & 8.0 & 8.2 & 8.3 & 8.3 & 8.4 & 8.2 & 7.8 \\
\hline 6 & 7.8 & 7.5 & 7.6 & 8.0 & 8.2 & 8.0 & 8.0 & 8.3 & 8.2 & 8.4 & 8.2 & 7.7 \\
\hline 7 & 7.9 & 7.4 & 7.7 & 7.9 & 8.2 & 8.0 & 7.8 & 8.4 & 8.2 & 8.4 & 8.2 & 7.7 \\
\hline 8 & 7.9 & 7.5 & 7.7 & 7.9 & 8.1 & 8.1 & 7.9 & 8.4 & 8.1 & 8.4 & 8.2 & 7.7 \\
\hline 9 & 7.9 & 7.5 & -.- & 8.0 & 8.0 & 8.0 & 8.0 & 8.4 & 8.2 & 8.3 & 8.2 & 7.7 \\
\hline 10 & 7.9 & 7.6 & 7.9 & 8.0 & 7.9 & 7.9 & 7.8 & 8.3 & 8.2 & 8.1 & 8.1 & 7.7 \\
\hline 11 & 7.8 & 7.6 & 7.9 & 8.1 & 7.9 & 7.8 & 7.8 & 8.3 & 8.2 & 8.2 & 8.2 & 7.7 \\
\hline 12 & 7.8 & 7.6 & 7.9 & 8.1 & 7.9 & 7.8 & 7.9 & 8.3 & 8.3 & 8.1 & 8.1 & 7.7 \\
\hline 13 & 7.9 & 7.7 & 7.9 & 8.1 & 8.0 & 7.9 & 7.9 & 8.3 & 8.3 & 8.1 & 8.1 & 7.7 \\
\hline 14 & 7.9 & 7.7 & 8.0 & 8.1 & 8.0 & 8.0 & 7.9 & 8.2 & 8.2 & 8.1 & 8.1 & 7.7 \\
\hline 15 & --- & 7.8 & 8.0 & 8.1 & 8.1 & 8.0 & 7.8 & 8.2 & 8.1 & 8.1 & 8.1 & 7.7 \\
\hline 16 & --- & 7.8 & 8.0 & 8.2 & 8.0 & 7.9 & 7.8 & 8.2 & 8.2 & 8.1 & 8.1 & 7.7 \\
\hline 17 & -.- & 7.9 & 8.0 & 8.2 & 7.9 & 7.8 & 7.8 & 8.3 & 8.2 & 8.1 & 8.1 & 7.7 \\
\hline 18 & --- & 7.7 & 8.0 & --- & 7.8 & 7.8 & 7.9 & 8.3 & 8.2 & 8.2 & --- & 7.7 \\
\hline 19 & --- & 7.6 & 8.0 & --- & 7.8 & 7.8 & 7.8 & 8.2 & 8.2 & 8.2 & 8.1 & 7.7 \\
\hline 20 & -- & 7.6 & 8.0 & -. & 7.7 & 7.9 & 7.8 & 8.2 & 8.2 & 8.2 & 7.9 & 7.7 \\
\hline 21 & --. & 7.7 & 8.0 & -. & 7.8 & 7.9 & 7.8 & 8.2 & 8.3 & 8.2 & 7.8 & 7.7 \\
\hline 22 & --- & 7.7 & 8.0 & 8.3 & 7.7 & 7.9 & 7.9 & 8.2 & 8.4 & 8.2 & 7.7 & 7.7 \\
\hline 23 & $\ldots$ & 7.7 & 8.0 & 8.3 & 7.7 & 8.0 & 7.9 & 8.3 & 8.3 & 8.3 & 7.7 & 7.7 \\
\hline 24 & --- & 7.7 & 8.0 & 8.3 & 7.8 & 8.0 & 8.0 & 8.2 & 8.2 & 8.3 & 7.7 & 7.7 \\
\hline 25 & --- & 7.6 & 8.0 & 8.3 & 7.8 & 8.0 & 8.1 & 8.0 & 8.2 & 8.3 & 7.8 & 7.7 \\
\hline 26 & --- & 7.5 & 8.0 & 8.4 & 7.9 & 8.1 & 8.1 & 8.0 & 8.2 & 8.3 & 7.8 & 7.7 \\
\hline 27 & 7.8 & 7.4 & 8.1 & 8.5 & 7.9 & 8.1 & 8.1 & 8.0 & 8.2 & 8.3 & 7.8 & 7.7 \\
\hline 28 & 7.8 & 7.4 & 8.2 & 8.4 & 7.9 & 8.1 & 8.1 & 8.1 & 8.3 & 8.3 & 7.8 & 7.7 \\
\hline 29 & --- & 7.3 & 8.2 & 8.3 & 8.0 & 8.1 & 8.1 & 8.2 & 8.3 & 8.3 & 7.8 & 7.7 \\
\hline 30 & --. & 7.3 & 8.2 & 8.4 & 7.9 & 8.1 & 8.1 & 8.2 & 8.4 & 8.3 & 7.8 & 7.7 \\
\hline 31 & --- & 7.4 & ... & 8.4 & --- & 8.1 & 8.2 & --- & 8.4 & --- & 7.8 & 7.7 \\
\hline Mean & 7.9 & 7.6 & 7.9 & 8.2 & 8.0 & 8.0 & 8.0 & 8.2 & 8.3 & 8.3 & 8.0 & 7.7 \\
\hline $\begin{array}{l}\text { Max- } \\
\text { imum }\end{array}$ & 8.0 & 7.9 & 8.2 & 8.5 & 8.5 & 8.1 & 8.2 & 8.4 & 8.4 & 8.4 & 8.2 & 7.8 \\
\hline $\begin{array}{l}\text { Min- } \\
\text { imum }\end{array}$ & 7.8 & 7.3 & 7.4 & 7.9 & 7.7 & 7.8 & 7.8 & 8.0 & 8.1 & 8.1 & 7.7 & 7.7 \\
\hline
\end{tabular}


Tabie 19. Mean daily $\mathrm{pH}$ of water from observation well CRM-4, February 1, 1993, through January 31, 1994

[pH given in standard units; ---, no data]

\begin{tabular}{|c|c|c|c|c|c|c|c|c|c|c|c|c|}
\hline Day & Feb. & Mar. & Apr. & May & June & July & Aug. & Sept. & Oct. & Nov. & Dec. & Jan \\
\hline 1 & 7.8 & $\cdots$ & 7.8 & 7.6 & 7.8 & 7.5 & 7.6 & 7.7 & 7.7 & $\cdots$ & 8.0 & 8.2 \\
\hline 2 & 7.8 & $\cdots$ & 7.8 & 7.6 & 7.8 & 7.4 & 7.6 & 7.7 & 7.7 & $\cdots$ & 8.0 & 8.2 \\
\hline 3 & 7.8 & 7.8 & 7.8 & 7.6 & 7.6 & 7.4 & 7.7 & 7.7 & 7.8 & -- & 8.0 & 8.2 \\
\hline 4 & 7.9 & 7.8 & 7.8 & 7.6 & 7.5 & 7.4 & 7.7 & 7.7 & 7.8 & --- & 8.1 & --- \\
\hline 5 & 7.9 & 7.8 & 7.8 & 7.6 & 7.6 & 7.4 & 7.7 & 7.7 & 7.8 & -.- & 8.1 & 8.1 \\
\hline 6 & 7.9 & 7.9 & 7.8 & 7.7 & 7.6 & 7.4 & 7.6 & 7.8 & 7.8 & $\cdots$ & 8.0 & 8.1 \\
\hline 7 & 7.9 & 8.0 & 7.8 & 7.7 & 7.6 & 7.4 & 7.5 & 7.8 & 7.8 & -- & 7.8 & 8.1 \\
\hline 8 & 7.9 & 8.0 & 7.8 & 7.7 & 7.6 & 7.4 & 7.5 & 7.7 & 7.8 & $\cdots$ & 7.9 & 8.1 \\
\hline 9 & 7.9 & 8.1 & --- & 7.7 & 7.6 & 7.4 & 7.6 & 7.7 & 7.9 & --- & 7.9 & 8.1 \\
\hline 10 & 7.7 & 8.1 & 7.8 & 7.7 & 7.6 & 7.4 & 7.6 & 7.5 & -- & 7.6 & 7.9 & 8.1 \\
\hline 11 & 7.7 & 8.1 & 7.8 & 7.7 & 7.6 & 7.4 & 7.6 & 7.4 & $\cdots$ & 7.6 & 7.9 & 8.1 \\
\hline 12 & 7.8 & 8.0 & 7.7 & 7.8 & 7.6 & 7.4 & 7.6 & 7.4 & -.. & 7.6 & 8.0 & 8.1 \\
\hline 13 & 7.8 & 8.0 & 7.7 & 7.8 & 7.6 & 7.5 & 7.6 & 7.4 & -.. & 7.7 & 8.0 & 8.1 \\
\hline 14 & 7.8 & 8.0 & 7.7 & 7.8 & 7.6 & 7.5 & 7.7 & 7.4 & 7.6 & 7.7 & 8.0 & 8.1 \\
\hline 15 & 7.8 & 8.0 & 7.7 & 7.8 & 7.6 & 7.5 & 7.7 & 7.5 & 7.6 & 7.7 & 8.0 & 8.1 \\
\hline 16 & 7.8 & 8.0 & 7.6 & 7.8 & 7.6 & 7.5 & 7.7 & 7.5 & 7.6 & 7.7 & 8.0 & 8.1 \\
\hline 17 & 7.8 & 8.0 & --. & 7.8 & 7.6 & 7.5 & 7.7 & 7.5 & 7.7 & 7.7 & 8.0 & 8.1 \\
\hline 18 & 7.8 & 7.9 & ... & 7.7 & 7.6 & 7.5 & 7.7 & 7.5 & 7.8 & 7.7 & 8.1 & -.. \\
\hline 19 & 7.7 & 7.8 & $\ldots$ & 7.6 & 7.6 & 7.5 & 7.7 & 7.5 & 7.8 & 7.7 & 8.2 & $\cdots$ \\
\hline 20 & 7.8 & 7.8 & -- & 7.6 & 7.6 & 7.6 & 7.7 & 7.5 & 7.8 & 7.7 & 8.2 & -.- \\
\hline 21 & 7.7 & 7.8 & -.- & 7.6 & 7.5 & 7.6 & 7.7 & 7.5 & 7.8 & 7.7 & 8.2 & -- \\
\hline 22 & 7.7 & 7.8 & --- & 7.6 & 7.5 & 7.6 & 7.8 & 7.6 & 7.8 & 7.7 & 8.2 & 7.8 \\
\hline 23 & 7.7 & 7.8 & --- & 7.6 & 7.5 & 7.6 & 7.8 & 7.6 & 7.8 & 7.8 & 8.2 & 7.8 \\
\hline 24 & 7.7 & 7.9 & 7.5 & 7.7 & 7.6 & 7.7 & 7.7 & 7.6 & 7.8 & 7.9 & 8.2 & 7.7 \\
\hline 25 & 7.7 & 7.8 & 7.6 & 7.7 & 7.6 & 7.7 & 7.7 & 7.6 & 7.8 & 7.9 & 8.2 & 7.7 \\
\hline 26 & 7.7 & 7.7 & 7.6 & 7.7 & 7.6 & 7.6 & 7.7 & 7.7 & $\cdots$ & 7.9 & 8.2 & 7.7 \\
\hline 27 & 7.7 & 7.7 & 7.6 & 7.7 & 7.6 & 7.6 & 7.7 & 7.7 & --- & 8.0 & 8.2 & 7.7 \\
\hline 28 & ... & 7.8 & 7.6 & 7.7 & 7.6 & 7.6 & 7.7 & 7.7 & --- & 8.0 & 8.2 & 7.7 \\
\hline 29 & $\cdots$ & 7.8 & 7.6 & 7.7 & 7.6 & 7.6 & 7.7 & 7.7 & --- & 8.0 & 8.2 & 7.7 \\
\hline 30 & ... & 7.8 & 7.6 & 7.7 & 7.6 & 7.6 & 7.7 & 7.7 & --- & 8.0 & 8.2 & 7.7 \\
\hline 31 & --- & 7.8 & $\cdots$ & 7.8 & $\cdots$ & 7.6 & 7.7 & --- & $\cdots$ & $\cdots$ & 8.2 & 7.7 \\
\hline Mean & 7.8 & 7.9 & 7.7 & 7.7 & 7.6 & 7.5 & 7.7 & 7.6 & 7.8 & 7.8 & 8.1 & 8.0 \\
\hline $\begin{array}{l}\text { Max- } \\
\text { imum }\end{array}$ & 7.9 & 8.1 & 7.8 & 7.8 & 7.8 & 7.7 & 7.8 & 7.8 & 7.9 & 8.0 & 8.2 & 8.2 \\
\hline $\begin{array}{l}\text { Min- } \\
\text { imum }\end{array}$ & 7.7 & 7.5 & 7.6 & 7.5 & 7.4 & 7.5 & 7.4 & 7.6 & 7.6 & 7.8 & 7.7 & 7.7 \\
\hline
\end{tabular}


Table 20. Mean daily $\mathrm{pH}$ of water from municipal well Seminole 10, February 1, 1993, through January 31, 1994

[pH. given in standard units; --.. no data]

\begin{tabular}{|c|c|c|c|c|c|c|c|c|c|c|c|c|}
\hline Day & Feb. & Mar. & Apr. & May & June & July & Aug. & Sept. & Oct. & Nov. & Dec. & Jan. \\
\hline 1 & 7.4 & $\cdots$ & --- & 7.6 & 7.8 & --- & 7.7 & 7.8 & 7.6 & $\cdots$ & 7.7 & 7.8 \\
\hline 2 & 7.4 & $\ldots$ & --- & 7.6 & 7.8 & 7.6 & 7.7 & 7.8 & 7.6 & ..- & 7.7 & 7.8 \\
\hline 3 & 7.4 & 7.4 & $\ldots$ & 7.6 & 7.6 & 7.6 & 7.7 & 7.8 & 7.6 & $\ldots$ & 7.7 & 7.8 \\
\hline 4 & 7.4 & 7.4 & ... & 7.6 & 7.5 & 7.7 & 7.7 & 7.8 & 7.6 & $\ldots$ & 7.7 & ... \\
\hline 5 & 7.4 & 7.4 & --- & 7.6 & 7.5 & 7.7 & 7.7 & 7.9 & 7.6 & $\ldots$ & 7.7 & 7.6 \\
\hline 6 & 7.4 & 7.4 & --- & 7.6 & 7.5 & 7.7 & 7.6 & 7.9 & 7.6 & -.- & 7.7 & 7.6 \\
\hline 7 & 7.4 & 7.5 & --- & 7.7 & 7.5 & 7.7 & 7.6 & 7.9 & 7.7 & $\ldots$ & 7.7 & 7.7 \\
\hline 8 & $\cdots$ & 7.5 & --. & 7.7 & 7.5 & 7.7 & 7.7 & 7.9 & 7.7 & -- & 7.7 & 7.7 \\
\hline 9 & -.. & 7.5 & --- & 7.7 & 7.6 & 7.7 & 7.7 & 7.9 & 7.7 & ..- & 7.7 & 7.7 \\
\hline 10 & 7.2 & 7.5 & 7.7 & 7.7 & 7.6 & 7.7 & 7.7 & 7.8 & 7.7 & 7.4 & 7.5 & 7.7 \\
\hline 11 & 7.3 & 7.5 & 7.8 & 7.7 & 7.6 & 7.7 & 7.7 & 7.7 & 7.7 & 7.4 & 7.5 & 7.7 \\
\hline 12 & 7.5 & 7.5 & 7.8 & 7.8 & 7.5 & 7.8 & 7.7 & 7.7 & 7.6 & 7.5 & 7.5 & 7.7 \\
\hline 13 & 7.5 & 7.6 & 7.8 & 7.8 & 7.5 & 7.8 & 7.7 & 7.7 & 7.7 & 7.5 & 7.6 & 7.7 \\
\hline 14. & 7.5 & 7.6 & 7.8 & 7.8 & 7.5 & 7.8 & 7.7 & 7.7 & 7.7 & 7.5 & 7.6 & 7.7 \\
\hline 15 & 7.5 & 7.6 & 7.8 & 7.7 & 7.5 & 7.8 & 7.8 & 7.7 & 7.8 & 7.5 & 7.6 & 7.7 \\
\hline 16 & 7.6 & 7.7 & 7.7 & 7.7 & 7.6 & 7.6 & 7.8 & 7.7 & 7.8 & 7.5 & 7.6 & 7.7 \\
\hline 17 & 7.5 & 7.7 & 7.7 & 7.7 & 7.6 & 7.5 & 7.8 & 7.8 & 7.9 & 7.6 & 7.7 & --- \\
\hline 18 & 7.4 & 7.7 & 7.7 & 7.7 & 7.5 & 7.5 & 7.8 & 7.8 & 7.9 & 7.6 & 7.6 & $\ldots$ \\
\hline 19 & 7.5 & 7.7 & 7.7 & 7.6 & 7.5 & 7.6 & 7.8 & 7.8 & 7.9 & 7.6 & 7.6 & --. \\
\hline 20 & 7.6 & 7.6 & 7.8 & 7.6 & 7.5 & 7.5 & 7.8 & 7.8 & 7.9 & 7.6 & 7.6 & --- \\
\hline 21 & 7.6 & 7.6 & 7.9 & 7.6 & 7.6 & 7.5 & 7.9 & 7.8 & 8.0 & 7.6 & 7.6 & --. \\
\hline 22 & 7.7 & 7.6 & 7.7 & 7.6 & 7.6 & 7.5 & 7.9 & 7.8 & 8.0 & 7.6 & 7.7 & 7.6 \\
\hline 23 & 7.7 & 7.6 & 7.6 & 7.7 & 7.6 & 7.5 & 7.9 & 7.8 & 8.0 & 7.6 & 7.7 & 7.6 \\
\hline 24 & 7.7 & 7.6 & 7.6 & 7.7 & 7.5 & 7.5 & 7.7 & 7.6 & 8.0 & 7.6 & 7.7 & 7.6 \\
\hline 25 & 7.7 & 7.6 & 7.6 & 7.8 & 7.6 & 7.5 & 7.7 & 7.6 & 8.0 & 7.7 & 7.8 & 7.6 \\
\hline 26 & 7.7 & 7.6 & 7.6 & 7.8 & 7.6 & 7.6 & 7.7 & 7.6 & 8.0 & 7.7 & 7.8 & 7.7 \\
\hline 27 & -- & -.- & 7.6 & 7.8 & 7.5 & 7.6 & 7.7 & 7.6 & 8.0 & 7.7 & 7.8 & 7.7 \\
\hline 28 & -- & -- & 7.6 & 7.8 & 7.6 & 7.6 & 7.8 & 7.6 & -.. & 7.7 & 7.8 & 7.7 \\
\hline 29 & ... & ... & 7.6 & 7.8 & 7.6 & 7.7. & 7.8 & 7.6 & ... & 7.7 & 7.8 & 7.7 \\
\hline 30 & -.. & ... & 7.6 & 7.8 & $\ldots$ & 7.7 & 7.8 & 7.6 & $\cdots$ & 7.7 & 7.8 & 7.7 \\
\hline 31 & -- &.-- & -.. & 7.8 & -.. & 7.7 & 7.8 & ... & $\cdots$ & $\ldots$ & 7.8 & 7.7 \\
\hline Mean & 7.5 & 7.6 & 7.7 & 7.7 & 7.6 & 7.6 & 7.7 & 7.7 & 7.8 & 7.6 & 7.7 & 7.7 \\
\hline $\begin{array}{l}\text { Max- } \\
\text { imum }\end{array}$ & 7.7 & 7.7 & 7.9 & 7.8 & 7.8 & 7.8 & 7.9 & 7.9 & 8.0 & 7.7 & 7.8 & 7.8 \\
\hline $\begin{array}{l}\text { Min- } \\
\text { imum }\end{array}$ & 7.2 & 7.4 & 7.6 & 7.6 & 7.5 & 7.5 & 7.6 & 7.6 & 7.6 & 7.4 & 7.5 & 7.6 \\
\hline
\end{tabular}


Table 21. Mean daily $\mathrm{pH}$ of water from observation well CRM-3, February 1, 1993, through January 31, 1994

$[\mathrm{pH}$, given in standard units; $\cdots$, no data]

\begin{tabular}{|c|c|c|c|c|c|c|c|c|c|c|c|c|}
\hline Day & Feb. & Mar. & Apr. & May & June & July & Aug. & Sept. & Oct. & Nov. & Dec. & Jan. \\
\hline 1 & -.- & ..- & 7.4 & 7.3 & 7.4 & 7.3 & 7.3 & 7.1 & 7.1 & $\ldots$ & 7.3 & 7.4 \\
\hline 2 & -.- & --. & 7.4 & 7.3 & 7.4 & 7.2 & 7.3 & 7.0 & 7.1 & --- & 7.3 & 7.4 \\
\hline 3 & --- & 7.2 & 7.4 & 7.3 & 7.3 & 7.2 & 7.3 & 7.0 & 7.1 & --. & 7.3 & 7.4 \\
\hline 4 & --- & 7.2 & 7.4 & 7.3 & 7.2 & 7.2 & 7.3 & 7.0 & 7.1 & --- & 7.3 & -.. \\
\hline 5 & -- & --- & 7.4 & 7.3 & 7.2 & 7.2 & 7.3 & 7.0 & 7.1 & --- & 7.3 & 7.4 \\
\hline 6 & --- & --- & 7.4 & 7.3 & 7.2 & 7.2 & 7.2 & 7.0 & 7.1 & --- & 7.2 & 7.4 \\
\hline 7 & -.- & --. & 7.4 & 7.3 & 7.2 & 7.2 & 7.1 & 7.0 & 7.1 & --- & 7.2 & 7.4 \\
\hline 8 & -- & 7.2 & 7.4 & 7.3 & 7.2 & 7.2 & 7.1 & 7.0 & 7.1 & -.- & 7.2 & 7.4 \\
\hline 9 & -- & 7.2 & -.. & 7.3 & 7.2 & 7.2 & 7.1 & 7.1 & 7.1 & -.. & 7.2 & 7.4 \\
\hline 10 & 7.3 & 7.2 & 7.2 & 7.3 & 7.2 & 7.1 & 7.2 & --- & 7.1 & 7.0 & 7.2 & 7.4 \\
\hline 11 & 7.3 & 7.3 & 7.2 & 7.4 & 7.2 & 7.1 & 7.2 & 7.0 & 7.1 & 7.0 & 7.2 & 7.4 \\
\hline 12 & 7.3 & 7.3 & 7.2 & 7.4 & 7.2 & 7.1 & 7.2 & 7.1 & 7.1 & 7.1 & 7.2 & 7.4 \\
\hline 13 & 7.3 & 7.3 & 7.2 & 7.4 & 7.3 & 7.2 & 7.2 & 7.1 & 7.0 & 7.1 & 7.2 & 7.4 \\
\hline 14 & 7.3 & 7.3 & 7.2 & 7.4 & 7.3 & 7.2 & 7.2 & 7.1 & 7.0 & 7.1 & 7.2 & 7.4 \\
\hline 15 & 7.2 & 7.3 & 7.2 & 7.4 & 7.3 & 7.2 & 7.2 & 7.1 & 7.0 & 7.1 & 7.2 & 7.4 \\
\hline 16 & 7.2 & 7.3 & 7.2 & 7.4 & 7.2 & 7.2 & 7.2 & 7.1 & 7.0 & 7.1 & 7.2 & 7.4 \\
\hline 17 & 7.3 & 7.3 & 7.2 & 7.4 & 7.2 & 7.2 & 7.2 & 7.1 & 7.1 & 7.1 & 7.2 & 7.4 \\
\hline 18 & 7.2 & ... & 7.2 & 7.3 & 7.3 & 7.2 & 7.2 & 7.1 & 7.1 & 7.1 & -.. & 7.4 \\
\hline 19 & 7.2 & --- & 7.2 & 7.3 & 7.3 & 7.2 & 7.2 & 7.1 & 7.1 & 7.1 & 7.2 & 7.4 \\
\hline 20 & 7.2 & 7.2 & 7.2 & 7.3 & 7.3 & 7.3 & 7.2 & 7.1 & 7.1 & 7.1 & 7.2 & 7.5 \\
\hline 21 & 7.2 & 7.2 & 7.2 & 7.3 & 7.3 & 7.3 & 7.2 & 7.1 & 7.1 & 7.1 & 7.3 & -.- \\
\hline 22 & 7.2 & 7.2 & 7.2 & 7.3 & 7.3 & 7.3 & 7.2 & 7.1 & 7.1 & 7.1 & 7.3 & 7.1 \\
\hline 23 & 7.2 & 7.2 & 7.2 & 7.3 & 7.3 & 7.3 & 7.2 & 7.2 & 7.1 & 7.2 & 7.3 & 7.1 \\
\hline 24 & 7.2 & 7.2 & 7.2 & 7.3 & 7.3 & 7.3 & 7.2 & 7.1 & 7.1 & 7.2 & 7.3 & 7.1 \\
\hline 25 & 7.2 & --- & 7.2 & 7.3 & 7.3 & 7.3 & 7.1 & 7.0 & 6.9 & 7.2 & 7.3 & 7.1 \\
\hline 26 & 7.2 & -.- & 7.1 & 7.3 & 7.3 & 7.3 & 7.1 & 7.1 & --- & 7.2 & 7.3 & 7.1 \\
\hline 27 & --- & 7.3 & 7.2 & 7.3 & 7.3 & 7.3 & 7.1 & 7.1 & --- & 7.2 & 7.3 & 7.1 \\
\hline 28 & --- & 7.3 & 7.2 & 7.3 & 7.3 & 7.3 & 7.1 & 7.1 & -.. & 7.3 & 7.3 & 7.2 \\
\hline 29 & --- & 7.3 & 7.2 & 7.3 & 7.3 & 7.3 & 7.1 & 7.1 & --- & 7.3 & 7.3 & 7.2 \\
\hline 30 & --- & 7.3 & 7.2 & 7.3 & 7.3 & 7.3 & 7.1 & 7.1 & --- & 7.3 & 7.4 & 7.2 \\
\hline 31 & -- & 7.3 & --- & 7.3 & --- & 7.3 & 7.1 & --- & --- & ..- & 7.4 & 7.2 \\
\hline Mean & 7.2 & 7.3 & 7.3 & 7.3 & 7.3 & 7.2 & 7.2 & 7.1 & 7.1 & 7.1 & 7.3 & 7.3 \\
\hline $\begin{array}{l}\text { Max- } \\
\text { imum }\end{array}$ & 7.3 & 7.3 & 7.4 & 7.4 & 7.4 & 7.3 & 7.3 & 7.2 & 7.1 & 7.3 & 7.4 & 7.5 \\
\hline $\begin{array}{l}\text { Min- } \\
\text { imum }\end{array}$ & 7.2 & 7.2 & 7.1 & 7.3 & 7.2 & 7.1 & 7.1 & 7.0 & 6.9 & 7.0 & 7.2 & 7.1 \\
\hline
\end{tabular}


Table 22. Mean daily $\mathrm{pH}$ of water from the Cedar Rapids municipal water-treatment plant, February 1, 1993, through January 31, 1994

[pH given in standard units; ---, no data]

\begin{tabular}{|c|c|c|c|c|c|c|c|c|c|c|c|c|}
\hline Day & Feb. & Mar. & Apr. & May & June & July & Aug. & Sept. & Oct. & Nov. & Dec. & Jan. \\
\hline 1 & $\cdots$ & 7.3 & 7.3 & 7.2 & 7.5 & 7.4 & $-\cdots$ & 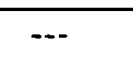 & 6.9 & 7.3 & 7.3 & $\cdots$ \\
\hline 2 & $\ldots$ & 7.3 & 7.3 & 7.2 & 7.5 & 7.4 & --- & --- & 6.9 & 7.3 & 7.3 & --- \\
\hline 3 & -- & 7.3 & 7.3 & 7.2 & 7.4 & 7.4 & --. & --- & 6.9 & 7.3 & 7.3 & -.. \\
\hline 4 & -.. & 7.3 & 7.3 & 7.2 & 7.3 & 7.4 & ... & -.. & 7.0 & 7.3 & 7.3 & -.. \\
\hline 5 & -- & 7.3 & 7.3 & 7.2 & 7.3 & 7.4 & --- & --. & 7.0 & 7.3 & 7.3 & 6.3 \\
\hline 6 & --- & 7.3 & 7.4 & 7.2 & 7.3 & 7.4 & -.. & --. & 7.0 & 7.3 & $-\cdots$ & 6.3 \\
\hline 7 & --- & 7.3 & $\ldots$ & 7.2 & 7.3 & 7.4 & 7.2 & --. & 7.0 & 7.3 & 7.3 & 6.3 \\
\hline 8 & $\ldots$ & 7.3 & --. & 7.3 & 7.3 & --- & 7.2 & -.. & 7.0 & 7.4 & 7.3 & 6.3 \\
\hline 9 & --- & 7.3 & -.- & 7.3 & 7.3 & --- & 7.2 & -.- & 7.0 & 7.3 & 7.3 & 6.3 \\
\hline 10 & --- & --. & 7.3 & 7.3 & 7.3 & --- & 7.2 & --- & 7.0 & 7.2 & 7.3 & 6.3 \\
\hline 11 & --. & 7.3 & 7.4 & 7.2 & 7.3 & --- & 7.2 & 7.2 & 7.0 & 7.3 & 7.3 & 6.3 \\
\hline 12 & $\ldots$ & 7.3 & 7.3 & 7.2 & 7.3 & -.. & 7.2 & 7.2 & 7.0 & 7.3 & 7.3 & 6.3 \\
\hline 13 & -- & 7.3 & 7.3 & 7.2 & 7.3 & -.- & 7.2 & 7.2 & 7.1 & 7.3 & 7.3 & 6.3 \\
\hline 14 & --- & 7.3 & 7.3 & 7.2 & 7.3 & -.- & 7.2 & 7.2 & 7.3 & 7.3 & 7.3 & 6.3 \\
\hline 15 & --- & 7.3 & 7.3 & 7.2 & 7.3 & -.- & 7.2 & 7.2 & 7.3 & 7.3 & 7.3 & 6.3 \\
\hline 16 & $\ldots$ & 7.3 & 7.4 & 7.2 & 7.3 & -- & 7.2 & 7.3 & 7.3 & 7.3 & 7.3 & 6.4 \\
\hline 17 & 7.2 & 7.3 & 7.4 & 7.2 & 7.3 & --. & 7.2 & 7.3 & 7.3 & 7.3 & 7.3 & 6.4 \\
\hline 18 & 7.2 & 7.3 & 7.4 & 7.2 & 7.3 & --- & 7.2 & 7.3 & 7.3 & 7.3 & -.. & 6.4 \\
\hline 19 & 7.2 & 7.3 & 7.4 & 7.2 & 7.3 & -.. & 7.2 & 7.3 & 7.3 & 7.3 & 7.2 & 6.4 \\
\hline 20 & 7.2 & 7.3 & 7.4 & 7.2 & 7.3 & --- & 7.2 & 7.3 & 7.3 & 7.3 & 7.3 & 6.4 \\
\hline 21 & 7.2 & 7.3 & 7.4 & 7.3 & .7 .3 & --- & 7.2 & 7.3 & 7.3 & 7.3 & 7.3 & $\ldots$ \\
\hline 22 & 7.2 & 7.3 & 7.4 & 7.5 & 7.3 & --- & 7.2 & 7.3 & 7.3 & 7.3 & 7.3 & 6.4 \\
\hline 23 & 7.2 & 7.3 & 7.4 & 7.5 & 7.3 & --- & 7.2 & 7.2 & 7.3 & 7.2 & 7.3 & 6.4 \\
\hline 24 & 7.2 & 7.3 & 7.4 & 7.5 & 7.3 & --- & 7.0 & 7.1 & 7.3 & 7.2 & 7.4 & 6.4 \\
\hline 25 & 7.3 & --. & 7.4 & 7.5 & 7.3 & $\cdots$ & 6.7 & 7.1 & 7.3 & 7.2 & 7.3 & 6.4 \\
\hline 26 & 7.3 & 7.3 & 7.4 & 7.5 & 7.3 & --- & 6.7 & 7.1 & 7.3 & 7.2 & -.. & 6.4 \\
\hline 27 & 7.3 & 7.3 & 7.3 & 7.5 & 7.3 & --- & -- & 7.0 & 7.3 & 7.2 & -.- & 6.4 \\
\hline 28 & 7.3 & 7.3 & 7.2 & 7.5 & 7.4 & --- & -- & 6.9 & 7.3 & 7.2 & --- & 6.4 \\
\hline 29 & --- & 7.3 & 7.2 & 7.5 & 7.3 & --- & -- & 6.9 & 7.3 & 7.3 & --- & 6.4 \\
\hline 30 & -- & 7.3 & 7.2 & 7.5 & 7.4 & --- & ... & 6.9 & 7.3 & 7.3 & --- & 6.4 \\
\hline 31 & -- & 7.3 & -- & 7.5 & --- & --- & --- & $\cdots$ & 7.3 & --- & -.. & 6.4 \\
\hline Mean & 7.2 & 7.3 & 7.3 & 7.3 & 7.3 & 7.4 & 7.1 & 7.2 & 7.2 & 7.3 & 7.3 & 6.4 \\
\hline $\begin{array}{l}\text { Max- } \\
\text { imum }\end{array}$ & 7.3 & 7.3 & 7.4 & 7.5 & 7.5 & 7.4 & 7.2 & 7.3 & 7.3 & 7.4 & 7.4 & 6.4 \\
\hline $\begin{array}{l}\text { Min- } \\
\text { imum }\end{array}$ & 7.2 & 7.3 & 7.2 & 7.2 & 7.3 & 7.4 & 6.7 & 6.9 & 6.9 & 7.2 & 7.2 & 6.3 \\
\hline
\end{tabular}


Table 23. Mean daily temperature of water from the Cedar River, surface-water monitoring site, February 1, 1993, through January 31, 1994

[Temperatures given in degrees Celsius; $\cdots$, no date]

\begin{tabular}{|c|c|c|c|c|c|c|c|c|c|c|c|c|}
\hline Day & Feb. & Mar. & Apr. & May & June & July & Aug. & Sept. & Oct. & Nov. & Dec. & Jan. \\
\hline 1 & -0.1 & -0.1 & 3.7 & 14.2 & 15.3 & 19.8 & 21.6 & 20.2 & 12.6 & 4.1 & 0.1 & -0.1 \\
\hline 2 & -.1 & -.1 & 3.4 & 13.9 & 14.1 & 20.6 & 21.6 & 19.9 & 12.5 & 4.3 & .8 & -.1 \\
\hline 3 & -.1 & -.1 & 3.6 & 13.7 & 13.5 & 21.9 & 21.5 & 19.6 & 12.4 & 5.0 & 1.3 & .1 \\
\hline 4 & -.1 & -.1 & 3.7 & 13.0 & 13.7 & 22.5 & 21.1 & 19.5 & 13.2 & 6.6 & 2.0 & -.1 \\
\hline 5 & -.1 & -.1 & 4.2 & 13.1 & 13.8 & 21.5 & 20.3 & 19.0 & 13.0 & 6.6 & 2.4 & -.1 \\
\hline 6 & -.1 & -.1 & 5.2 & 13.5 & 15.1 & 21.1 & 19.7 & 18.1 & 13.8 & 4.4 & 2.4 & -.1 \\
\hline 7 & -.1 & 0 & 6.4 & 14.4 & 15.7 & 21.1 & 19.9 & 18.1 & 15.6 & 3.0 & 1.6 & -.1 \\
\hline 8 & -.1 & .1 & 7.3 & 16.4 & 16.7 & 21.0 & 20.4 & 18.2 & 16.8 & 3.4 & 1.6 & -.1 \\
\hline 9 & -.1 & .1 & --- & 17.9 & 17.9 & 20.9 & 20.9 & 18.0 & 15.0 & 3.9 & 2.2 & -.1 \\
\hline 10 & -.1 & 0 & 8.1 & 18.4 & 18.8 & 21.2 & 21.4 & 17.3 & 12.6 & 4.4 & 2.2 & -.1 \\
\hline 11 & -.1 & 0 & 8.4 & 18.7 & 19.8 & 21.5 & 22.4 & 16.7 & 11.4 & 5.2 & .6 & -.1 \\
\hline 12 & -.1 & 0 & 7.9 & 19.1 & 20.4 & 21.9 & 23.0 & 17.5 & 11.2 & 5.0 & .2 & -.1 \\
\hline 13 & -.1 & .1 & 7.7 & 18.3 & 20.6 & 21.7 & 23.5 & 18.9 & 10.9 & 6.1 & 1.2 & -.1 \\
\hline 14 & -.1 & .2 & 7.1 & 18.0 & 21.1 & 21.4 & 23.6 & 17.7 & 11.3 & 6.0 & 1.7 & -.1 \\
\hline 15 & -- & .4 & 6.0 & 18.0 & 20.7 & 21.3 & 22.7 & 15.6 & 12.1 & 5.5 & 2.3 & -.1 \\
\hline 16 & --- & .5 & 4.8 & 17.4 & 19.7 & 21.3 & 22.6 & 14.7 & 12.7 & 4.7 & 2.8 & -.1 \\
\hline 17 & --- & .2 & 5.9 & 16.6 & 19.4 & 21.4 & 23.0 & 14.6 & 12.8 & 5.0 & 3.2 & -.1 \\
\hline 18 & --- & .1 & 7.4 & $\cdots$ & 20.3 & 21.6 & 23.3 & 14.9 & 12.2 & 4.5 & --- & -.1 \\
\hline 19 & --- & .1 & 8.5 & $\ldots$ & 20.5 & 21.9 & 22.9 & 14.6 & 12.4 & 4.6 & 3.3 & -.1 \\
\hline 20 & -.- & .2 & 8.1 & --- & 20.1 & 22.3 & 22.9 & 14.7 & 12.4 & 3.8 & 2.7 & -.1 \\
\hline 21 & -. & .1 & 8.8 & --- & 20.0 & 22.1 & 22.8 & 15.3 & 11.1 & 3.9 & 1.5 & -.1 \\
\hline 22 & -- & .1 & 9.3 & 13.9 & 20.7 & 21.6 & 22.4 & 16.0 & 10.2 & 4.3 & .4 & -.1 \\
\hline 23 & -- & .3 & 9.6 & 14.0 & 21.3 & 20.9 & 22.6 & 16.1 & 10.5 & 4.8 & -.1 & -.1 \\
\hline 24 & -.. & 1.6 & 10.3 & 14.1 & 21.5 & 21.0 & 23.1 & 15.6 & 11.1 & 4.9 & -.1 & -.1 \\
\hline 25 & --- & 2.5 & 10.8 & 14.1 & 21.5 & 21.8 & 23.6 & 14.9 & 11.6 & 4.3 & -.1 & -.1 \\
\hline 26 & ..- & 3.4 & 11.8 & 15.3 & 21.6 & 22.7 & 24.2 & 13.7 & 11.3 & 2.3 & -.1 & 0 \\
\hline 27 & -.1 & 3.3 & 12.2 & 16.9 & 22.0 & 23.2 & 24.6 & 12.9 & 9.8 & 1.0 & -.1 & 0 \\
\hline 28 & -.1 & 3.5 & 12.3 & 17.4 & 22.0 & 23.2 & 23.8 & 12.9 & 9.0 & .6 & -.1 & 0 \\
\hline 29 & $\cdots$ & 3.6 & 13.5 & 16.3 & 21.7 & 22.6 & 22.1 & 12.5 & 7.3 & .1 & -.1 & 0 \\
\hline 30 & -- & 3.7 & 14.1 & 16.0 & 20.5 & 22.7 & 21.4 & 12.1 & 5.7 & -.1 & -.1 & 0 \\
\hline 31 & -- & 4.2 & --- & 15.7 & $\cdots$ & 22.5 & 20.7 & --- & 4.6 & -- & -.1 & 0 \\
\hline Mean & -.1 & .9 & 7.9 & 15.9 & 19.0 & 21.7 & 22.2 & 16.3 & 11.6 & 4.1 & 1.2 & -.1 \\
\hline $\begin{array}{l}\text { Max- } \\
\text { imum }\end{array}$ & -.1 & 4.2 & 14.1 & 19.1 & 22.0 & 23.2 & 24.6 & 20.2 & 16.8 & 6.6 & 3.3 & 0 \\
\hline $\begin{array}{l}\text { Min- } \\
\text { imum }\end{array}$ & -.1 & -.1 & 3.4 & 13.0 & 13.5 & 19.8 & 19.7 & 12.1 & 4.6 & -.1 & -.1 & -.1 \\
\hline
\end{tabular}


Table 24. Mean daily temperature of water from observation well CRM-4, February 1, 1993, through January 31, 1994

[Temperatures given in degrees Celsius; ---, no data]

\begin{tabular}{|c|c|c|c|c|c|c|c|c|c|c|c|c|}
\hline Day & Feb. & Mar. & Apr. & May & June & July & Aug. & Sept. & Oct. & Nov. & Dec. & Jan. \\
\hline 1 & 0.9 & ... & 1.8 & 11.5 & 16.3 & --. & 23.3 & 23.9 & 15.3 & 11.4 & 4.7 & 0.1 \\
\hline 2 & .9 & $\ldots$ & 2.6 & 12.1 & 17.1 & --- & 22.9 & 24.4 & 14.6 & 11.1 & 3.8 & .1 \\
\hline 3 & .9 & 0.1 & 3.1 & 12.5 & 16.8 & $\cdots$ & 22.8 & 24.5 & 13.8 & 10.3 & 2.5 & .1 \\
\hline 4 & .9 & .1 & 3.3 & 13.6 & 16.4 & -.- & 22.9 & 23.8 & 13.3 & 9.4 & 1.5 & $\cdots$ \\
\hline 5 & .9 & .1 & 3.5 & 14.2 & 16.0 & $\cdots$ & 22.0 & 22.6 & 13.0 & 8.2 & .8 & .1 \\
\hline 6 & .9 & .1 & 3.6 & 14.3 & 15.6 & $\cdots$ & 21.8 & 21.7 & 12.8 & 6.8 & .4 & .1 \\
\hline 7 & .9 & .1 & 3.7 & 14.1 & 14.9 & $\cdots$ & 21.8 & 21.0 & 12.6 & 5.6 & .2 & .1 \\
\hline 8 & .9 & .1 & 3.9 & 14.1 & 14.4 & --. & 21.7 & 20.5 & 12.6 & 4.8 & .3 & .1 \\
\hline 9 & .9 & .1 & --- & 14.1 & 14.0 & -- & 21.7 & 20.1 & 12.6 & 4.8 & .8 & .1 \\
\hline 10 & .8 & .1 & 4.0 & 14.1 & 13.9 & -.- & 21.6 & 19.8 & --- & 5.3 & 1.5 & .1 \\
\hline 11 & .7 & .1 & 3.9 & 14.1 & 14.3 & --- & 21.3 & 19.6 & $\ldots$ & 5.9 & 1.7 & .1 \\
\hline 12 & .4 & .1 & 4.1 & 14.0 & 15.2 & --- & 20.8 & 19.1 & --- & 6.1 & 1.8 & .1 \\
\hline 13 & .2 & .1 & 4.7 & 14.0 & 15.4 & $\ldots$ & 20.6 & 18.6 & -- & 5.5 & 1.8 & .1 \\
\hline 14 & .1 & .1 & 5.9 & 13.7 & 15.6 & --. & 20.2 & 18.3 & 15.6 & 4.3 & 1.9 & .1 \\
\hline 15 & .1 & .2 & 7.2 & 13.3 & 15.7 & --- & 20.0 & 18.3 & 15.9 & 3.8 & 1.9 & .1 \\
\hline 16 & .1 & .2 & 8.0 & 13.3 & 15.9 & --- & 20.2 & 18.2 & 15.0 & 4.1 & 1.9 & .1 \\
\hline 17 & .1 & .2 & --- & 14.1 & 16.8 & 22.0 & 20.8 & 17.8 & 13.4 & 4.6 & 1.8 & .1 \\
\hline 18 & .1 & .3 & --. & 16.5 & 17.8 & 21.9 & 21.6 & 17.3 & 12.2 & 5.1 & 1.9 & --. \\
\hline 19 & .1 & .2 & $\cdots$ & 18.0 & 18.6 & 21.9 & 22.6 & 17.5 & 11.6 & 5.6 & 1.8 & --- \\
\hline 20 & .1 & .2 & --- & 18.1 & 19.4 & 21.9 & 23.3 & 18.4 & 11.4 & 6.0 & 1.8 & --- \\
\hline 21 & .1 & .3 & --- & 17.8 & 19.7 & 21.6 & 23.5 & 18.3 & 11.6 & 6.0 & 2.1 & -- \\
\hline 22 & .1 & .4 & -.. & 17.1 & 19.6 & 21.0 & 23.2 & 16.7 & 12.1 & 5.7 & 2.3 & .1 \\
\hline 23 & .1 & .5 & --- & 16.3 & 20.0 & 20.7 & 23.1 & 15.3 & 12.6 & 5.3 & 2.0 & .1 \\
\hline 24 & .1 & .5 & 8.2 & 15.5 & 20.4 & 20.6 & 23.4 & 15.0 & 12.7 & 5.0 & 1.9 & .1 \\
\hline 25 & .1 & .4 & 8.4 & 14.7 & 20.5 & 21.1 & 23.2 & 14.9 & 12.6 & 4.8 & 1.9 & .1 \\
\hline 26 & .1 & .3 & 8.7 & 14.1 & 20.4 & 21.9 & 23.1 & 15.1 & 12.4 & 4.5 & 2.2 & .1 \\
\hline 27 & .1 & .3 & 9.2 & 14.1 & 20.3 & 22.1 & 23.0 & 15.7 & 11.9 & 4.2 & 2.4 & .1 \\
\hline 28 & ..- & .3 & 9.6 & 14.1 & 20.5 & 21.5 & 22.9 & 16.1 & 11.2 & 4.3 & 1.5 & .1 \\
\hline 29 & -- & .4 & 10.1 & 14.2 & 21.0 & 21.4 & 22.7 & 16.1 & 10.8 & 4.6 & .6 & .1 \\
\hline 30 & -.. & .6 & 10.6 & 14.3 & 21.5 & 22.6 & 22.9 & 15.8 & 10.9 & 4.9 & .2 & .1 \\
\hline 31 & $\cdots$ & 1.1 & --. & 15.0 & -. & 23.5 & 23.4 & --- & 11.3 & $\cdots$ & .1 & .1 \\
\hline Mean & .4 & .3 & 5.8 & 14.5 & 17.5 & 21.7 & 22.2 & 18.8 & 12.8 & 5.9 & 1.7 & .1 \\
\hline $\begin{array}{l}\text { Max- } \\
\text { imum }\end{array}$ & .9 & 1.1 & 10.6 & 18.1 & 21.5 & 23.5 & 23.5 & 24.5 & 15.9 & 11.4 & 4.7 & .1 \\
\hline $\begin{array}{l}\text { Min- } \\
\text { imum }\end{array}$ & .1 & .1 & 1.8 & 11.5 & 13.9 & 20.6 & 20.0 & 14.9 & 10.8 & 3.8 & .1 & .1 \\
\hline
\end{tabular}


Table 25. Mean daily temperature of water from municipal well Seminole 10, February 1,1993 , through January 31, 1994

[Temperatures given in degrees Celsius; ---, no data]

\begin{tabular}{|c|c|c|c|c|c|c|c|c|c|c|c|c|}
\hline Day & Feb. & Mar. & Apr. & May & June & July & Aug. & Sept. & Oct. & Nov. & Dec. & Jan. \\
\hline 1 & 6.5 & -.. & $\cdots$ & 7.2 & 15.0 & $\cdots$ & 20.8 & 18.4 & 15.8 & 11.8 & 5.0 & 1.8 \\
\hline 2 & 6.5 & -.. & $\ldots$ & 7.5 & 14.8 & 17.1 & 20.9 & 18.5 & 15.7 & 11.7 & 4.9 & 1.8 \\
\hline 3 & 6.5 & -0.1 & --- & 8.0 & 14.7 & 14.5 & 21.0 & 18.5 & 15.5 & 11.6 & 4.9 & 1.7 \\
\hline 4 & 6.5 & -.1 & --- & 8.5 & 14.7 & 14.5 & 21.0 & 18.3 & 15.3 & 11.5 & 4.8 & -.- \\
\hline 5 & 6.5 & -.2 & -- & 9.0 & 14.7 & 14.4 & 21.1 & 18.5 & 15.0 & 11.4 & 4.7 & 1.3 \\
\hline 6 & 6.4 & -.2 & -.. & 9.5 & 14.7 & 15.7 & 21.0 & 20.3 & 14.6 & 11.2 & 4.5 & 1.1 \\
\hline 7 & 6.4 & -.2 & --- & 7.3 & 13.7 & 15.5 & 19.2 & 20.3 & 14.3 & 10.9 & 4.3 & .9 \\
\hline 8 & $\cdots$ & -.2 & -.. & 6.8 & 12.4 & 14.6 & 18.5 & 19.9 & 13.9 & 10.5 & 4.5 & .7 \\
\hline 9 & --. & -.2 & -.- & 6.7 & 15.1 & 13.6 & 19.2 & 20.2 & 13.6 & 10.1 & 4.4 & .5 \\
\hline 10 & 6.1 & -.2 & 2.2 & 6.8 & 15.3 & 13.6 & 19.2 & 20.8 & 13.4 & 9.5 & 6.8 & .4 \\
\hline 11 & 5.1 & -.2 & 2.5 & 7.3 & 15.4 & 13.6 & 19.6 & 21.1 & 13.2 & 8.9 & 6.4 & .3 \\
\hline 12 & 1.7 & -.2 & 2.8 & 7.3 & 13.1 & 14.4 & 19.6 & 21.2 & 13.0 & 8.2 & 6.4 & .2 \\
\hline 13 & 1.0 & -.2 & 3.0 & 8.3 & 12.5 & 14.6 & 18.8 & 21.4 & 13.0 & 7.8 & 6.5 & .1 \\
\hline 14 & .8 & -.2 & 3.1 & 10.2 & 12.8 & 14.2 & 19.9 & 20.6 & 13.0 & 7.2 & 6.5 & .1 \\
\hline 15 & .6 & -.2 & 3.3 & 10.8 & 12.7 & 13.7 & 18.5 & 21.2 & 13.2 & 6.7 & 6.5 & 0 \\
\hline 16 & .4 & -.2 & 3.4 & 11.3 & 13.8 & 13.7 & 19.5 & 21.1 & 13.5 & 6.3 & 6.6 & 0 \\
\hline 17 & 2.9 & -.1 & 3.7 & 11.8 & 15.1 & 13.7 & 20.3 & 21.2 & 13.8 & 5.9 & 6.6 & -.- \\
\hline 18 & 4.4 & -.1 & 4.1 & 12.0 & 15.0 & 13.4 & 20.1 & 21.0 & 13.9 & 5.7 & 6.6 & --. \\
\hline 19 & 4.4 & -.1 & 4.6 & 12.1 & 15.0 & 14.1 & 20.4 & 20.8 & 13.8 & 5.4 & 6.6 & -.. \\
\hline 20 & 4.5 & -.1 & 5.4 & 12.3 & 14.9 & 15.2 & 20.2 & 20.6 & 13.6 & 5.2 & 6.6 & $\cdots$ \\
\hline 21 & .7 & -.1 & 6.1 & 12.5 & 14.9 & 17.0 & 20.3 & 19.8 & 13.3 & 5.0 & 6.1 & $\cdots$ \\
\hline 22 & .2 & -.1 & 6.2 & 12.9 & 15.2 & 18.2 & 19.9 & 19.1 & 12.9 & 5.0 & 3.8 & -.1 \\
\hline 23 & 0 & -.1 & 6.3 & 13.2 & 15.5 & 18.6 & 19.7 & 18.7 & 12.6 & 5.0 & 2.7 & -.2 \\
\hline 24 & 0 & -.1 & 6.7 & 13.5 & 15.7 & 18.9 & 19.2 & 18.1 & 12.4 & 5.0 & 2.0 & -.2 \\
\hline 25 & -.1 & -.1 & 6.9 & 13.8 & 15.7 & 19.0 & 18.5 & 17.4 & 12.4 & 5.0 & 1.7 & -.1 \\
\hline 26 & -.1 & -.1 & 6.7 & 14.1 & 15.9 & 19.1 & 18.6 & 17.0 & 12.4 & 5.0 & 1.6 & -.2 \\
\hline 27 & -- & $\ldots$ & 6.5 & 14.5 & 16.2 & 19.6 & 18.7 & 16.6 & 12.4 & 5.0 & 1.6 & -.2 \\
\hline 28 & -.. & -- & 6.6 & 14.8 & 16.5 & 20.0 & 18.5 & 16.3 & 12.3 & 5.0 & 1.6 & -.2 \\
\hline 29 & --- & -.- & 6.8 & 15.1 & 16.9 & 20.3 & 18.5 & 16.0 & 12.2 & 5.0 & 1.6 & -.2 \\
\hline 30 & -.. & ... & 7.0 & 15.2 & -- & 20.5 & 18.4 & 15.9 & 12.1 & 5.0 & 1.7 & -.1 \\
\hline 31 & -.- & -- & $\cdots$ & 15.1 & -- & 20.7 & 18.2 & --- & 11.9 & $\cdots$ & 1.8 & -.1 \\
\hline Mean & 3.2 & -.2 & 4.9 & 10.8 & 14.8 & 16.2 & 19.6 & 19.3 & 13.5 & 7.6 & 4.5 & .4 \\
\hline $\begin{array}{l}\text { Max- } \\
\text { imum }\end{array}$ & 6.5 & -.1 & 7.0 & 15.2 & 16.9 & 20.7 & 21.1 & 21.4 & 15.8 & 11.8 & 6.8 & 1.8 \\
\hline $\begin{array}{l}\text { Min- } \\
\text { imum }\end{array}$ & -.1 & -.2 & 2.2 & 6.7 & 12.4 & 13.4 & 18.2 & 15.9 & 11.9 & 5.0 & 1.6 & -.2 \\
\hline
\end{tabular}


Table 26. Mean daily temperature of water from observation well CRM-3, February 1, 1993, through January 31, 1994

[Temperatures given in degrees Celsius; ---, no data]

\begin{tabular}{|c|c|c|c|c|c|c|c|c|c|c|c|c|}
\hline Day & Feb. & Mar. & Apr. & May & June & July & Aug. & Sept. & Oct. & Nov. & Dec. & Jan. \\
\hline 1 & $\ldots$ & $\cdots$ & 3.0 & 5.0 & 5.4 & 5.9 & 8.5 & 11.8 & 15.1 & 16.5 & 18.6 & 15.7 \\
\hline 2 & -. & -.. & 3.0 & 5.0 & 5.4 & 6.0 & 8.6 & 12.0 & 15.2 & 16.5 & 18.7 & 15.6 \\
\hline 3 & $\cdots$ & 3.4 & 2.9 & 5.1 & --. & 6.0 & 8.8 & 12.2 & 15.3 & .16 .6 & 18.6 & 15.4 \\
\hline 4 & $\ldots$ & 3.6 & 2.9 & 5.1 & 5.3 & 6.0 & 8.9 & 12.3 & 15.4 & 16.6 & 18.5 & -.- \\
\hline 5 & --- & --- & 2.9 & 5.0 & 5.2 & 6.0 & 9.1 & 12.5 & 15.5 & 16.6 & 18.4 & 15.1 \\
\hline 6 & --- & -- & 2.9 & 5.0 & 5.2 & 6.0 & 9.3 & 12.7 & 15.7 & 16.7 & --. & 15.0 \\
\hline 7 &.- & $\ldots$ & 3.0 & 5.0 & 5.1 & 6.0 & 9.3 & 12.9 & 15.8 & 16.8 & 18.3 & 14.8 \\
\hline 8 &.-- & 3.1 & 3.2 & 5.0 & 5.1 & 6.0 & 9.5 & 13.2 & 15.9 & 16.8 & 18.2 & 14.7 \\
\hline 9 & -- & 3.0 & --- & 5.0 & 5.0 & 6.0 & 9.9 & 13.4 & 16.0 & 17.0 & 18.0 & 14.6 \\
\hline 10 & 0.6 & 3.0 & 3.6 & 5.0 & 5.0 & 6.0 & 10.3 & -.- & 16.2 & 17.1 & 17.7 & 14.4 \\
\hline 11 & .6 & 3.0 & 3.7 & 5.0 & 4.9 & 6.0 & 10.4 & 13.9 & 16.3 & 17.1 & 17.2 & 14.3 \\
\hline 12 & .6 & 3.0 & 3.8 & 5.0 & 5.0 & 6.1 & 10.2 & 14.0 & 16.2 & 17.2 & 16.8 & 14.2 \\
\hline 13 & .6 & 3.0 & 3.9 & 4.9 & 5.0 & 6.1 & 10.3 & 14.2 & 16.1 & 17.3 & 16.6 & 14.1 \\
\hline 14 & .7 & 3.0 & 4.0 & 4.9 & 5.0 & 6.1 & 10.6 & 14.3 & 16.1 & 17.3 & 16.5 & 14.0 \\
\hline 15 & .7 & 3.0 & 4.1 & 4.9 & 5.1 & 6.1 & 10.7 & 14.6 & 16.1 & 17.4 & 16.5 & 13.9 \\
\hline 16 & .8 & 3.0 & 4.2 & 4.9 & 5.1 & --- & 11.3 & 14.7 & 16.1 & 17.5 & 16.3 & 13.8 \\
\hline 17 & .9 & 3.0 & 4.2 & 4.9 & 5.0 & 6.1 & 11.7 & 14.9 & 16.2 & 17.5 & 15.8 & 13.7 \\
\hline 18 & $\ldots$ & $\cdots$ & 4.3 & 4.9 & 5.0 & 6.1 & 11.5 & 15.0 & 16.2 & 17.7 & --- & 13.6 \\
\hline 19 & 1.0 & --- & 4.3 & 4.9 & 5.0 & 6.1 & 11.4 & 15.2 & 16.2 & 17.8 & 13.9 & 13.5 \\
\hline 20 & 1.1 & 3.0 & 4.3 & 4.9 & 5.0 & 6.2 & 11.4 & 15.4 & 16.3 & 18.0 & 12.6 & 13.5 \\
\hline 21 & 1.3 & 3.1 & 4.4 & 4.9 & 5.1 & 6.4 & 11.5 & 15.4 & 16.3 & 18.1 & 11.6 & --- \\
\hline 22 & 1.5 & 3.3 & 4.4 & 4.9 & 5.1 & 6.5 & 11.6 & 15.4 & 16.3 & 18.1 & 12.6 & 13.2 \\
\hline 23 & 1.6 & 3.3 & 4.4 & 5.0 & 5.1 & 6.6 & 11.7 & 15.3 & 16.3 & 18.2 & 14.2 & 13.1 \\
\hline 24 & 1.8 & 3.3 & 4.4 & 5.0 & 5.2 & 6.7 & 11.8 & 15.4 & 16.3 & 18.2 & 15.1 & 13.1 \\
\hline 25 & 2.0 & -- & 4.5 & 5.1 & 5.2 & 6.9 & 11.8 & 15.3 & 16.3 & 18.3 & 15.7 & 13.0 \\
\hline 26 & 2.3 & $\ldots$ & 4.5 & 5.2 & 5.3 & 7.1 & 11.7 & 15.3 & 16.3 & 18.3 & 15.9 & 12.9 \\
\hline 27 & $\cdots$ & 3.3 & 4.6 & 5.2 & 5.3 & 7.3 & 11.6 & 15.3 & 16.3 & 18.4 & 16.0 & 12.8 \\
\hline 28 & -- & 3.2 & 4.7 & 5.2 & 5.5 & 7.5 & 11.7 & 15.2 & 16.3 & 18.4 & 16.0 & 12.7 \\
\hline 29 & $\cdots$ & 3.2 & 4.8 & 5.3 & 5.6 & 7.8 & 11.6 & 15.1 & 16.4 & 18.4 & 15.9 & 12.6 \\
\hline 30 & -.. & 3.1 & 4.9 & 5.3 & 5.7 & 8.1 & 11.6 & 15.1 & 16.4 & 18.5 & 15.8 & 12.5 \\
\hline 31 & -- & 3.0 & -- & 5.3 & --- & 8.3 & 11.7 & -- & 16.4 & --- & 15.7 & 12.4 \\
\hline Mean & 1.1 & 3.1 & 3.9 & 5.0 & 5.2 & 6.5 & 10.6 & 14.2 & 16.0 & 17.5 & 16.3 & 13.9 \\
\hline $\begin{array}{l}\text { Max- } \\
\text { imum }\end{array}$ & 2.3 & 3.6 & 4.9 & 5.3 & 5.7 & 8.3 & 11.8 & 15.4 & 16.4 & 18.5 & 18.7 & 15.7 \\
\hline $\begin{array}{l}\text { Min- } \\
\text { imum }\end{array}$ & .6 & 3.0 & 2.9 & 4.9 & 4.9 & 5.9 & 8.5 & 11.8 & 15.1 & 16.5 & 11.6 & 12.4 \\
\hline
\end{tabular}


Table 27. Mean daily temperature of water from the Cedar Rapids municipal water-treatment plant, February 1, 1993, through January 31, 1994

[Temperatures given in degrees Celsius; $\cdots$, no data]

\begin{tabular}{|c|c|c|c|c|c|c|c|c|c|c|c|c|}
\hline Day & Feb. & Mar. & Apr. & May & June & July & Aug. & Sept. & Oct. & Nov. & Dec. & Jan. \\
\hline 1 & -.. & 10.7 & 8.0 & 7.8 & 11.4 & 12.9 & 16.8 & 16.7 & 16.4 & 14.2 & 11.5 & $\ldots$ \\
\hline 2 & .-- & 10.8 & 6.8 & 7.9 & 11.2 & 13.5 & 16.9 & 16.8 & 16.3 & 14.2 & 11.3 & $\cdots$ \\
\hline 3 & --- & 10.7 & 6.6 & 7.9 & 11.8 & 13.0 & 17.0 & 16.5 & 15.9 & 14.1 & 11.3 & $\cdots$ \\
\hline 4 & -.- & 10.5 & 6.8 & 8.0 & 12.0 & 13.3 & 16.9 & 17.5 & 15.9 & 14.1 & 11.2 & $\ldots$ \\
\hline 5 & -.. & 10.5 & 6.4 & 8.1 & 11.3 & 13.3 & 17.1 & 17.3 & 15.8 & 14.1 & 11.0 & 9.7 \\
\hline 6 & -.- & 10.5 & 6.7 & 8.3 & 10.8 & 14.0 & 17.3 & 16.8 & 15.6 & 14.0 & -- & 9.5 \\
\hline 7 & -.- & 10.5 & 7.2 & 8.7 & 11.5 & 14.0 & 16.7 & 17.3 & 16.2 & 13.8 & 11.0 & 9.4 \\
\hline 8 & --- & 10.5 & -.. & 8.2 & 12.2 & ..- & 16.6 & 16.8 & 15.9 & 13.8 & 10.9 & 9.3 \\
\hline 9 & -- & 10.3 & --- & 8.5 & 12.1 & --. & 17.3 & 16.8 & 15.8 & 13.7 & 10.8 & 8.9 \\
\hline 10 & -- & -.. & 5.9 & 8.8 & 11.5 & $\cdots$ & 16.7 & 17.1 & 15.8 & 13.5 & 10.6 & 8.4 \\
\hline 11 & --. & 9.3 & 6.0 & 9.6 & 11.5 & $\ldots$ & 16.4 & 17.2 & 15.3 & 13.4 & 10.7 & 8.5 \\
\hline 12 & -.- & 9.4 & 6.3 & 9.7 & 11.7 & --. & 16.9 & 17.2 & 15.7 & 13.1 & 10.7 & 8.9 \\
\hline 13 & $\ldots$ & 9.7 & 6.6 & 9.7 & 11.8 & --. & 17.0 & 17.6 & 15.6 & 13.2 & 10.4 & 8.6 \\
\hline 14 & -.- & 9.5 & 6.7 & 9.9 & 12.2 & ..- & 16.3 & 16.3 & 15.6 & 13.2 & 10.7 & 8.5 \\
\hline 15 & $\ldots$ & 9.4 & 6.8 & 9.8 & 12.1 & $\ldots$ & 17.3 & 16.2 & 15.7 & 13.0 & 10.7 & 8.7 \\
\hline 16 & $\ldots$ & 8.8 & 6.8 & 10.3 & 12.7 & --- & 17.3 & 17.0 & 15.5 & 12.6 & 10.6 & 8.4 \\
\hline 17 & 11.0 & 8.8 & 7.1 & 10.7 & 12.2 & 15.0 & 16.7 & 16.2 & 15.5 & 13.0 & 10.3 & 8.2 \\
\hline 18 & 11.4 & 9.4 & 7.1 & 11.2 & 11.1 & 14.7 & 16.7 & 16.0 & 15.3 & 13.1 & --- & 8.4 \\
\hline 19 & 11.1 & 9.0 & 7.0 & 11.3 & 11.2 & 15.1 & 17.2 & 16.0 & 14.8 & 12.8 & 10.2 & 8.7 \\
\hline 20 & 10.9 & 9.0 & 7.2 & 11.5 & 11.7 & 15.6 & 17.0 & 16.6 & 14.6 & 12.7 & 10.1 & 8.4 \\
\hline 21 & 10.5 & 9.0 & 7.3 & 11.0 & 11.8 & 15.3 & 15.4 & 16.8 & 14.6 & 12.5 & 10.1 & ... \\
\hline 22 & 10.4 & 9.6 & 7.5 & 10.8 & 12.0 & 14.7 & 16.4 & 16.9 & 14.5 & 12.5 & 10.1 & 8.4 \\
\hline 23 & 10.8 & 9.5 & 7.4 & 10.9 & 11.3 & 15.1 & 16.6 & 16.8 & 14.5 & 12.4 & 10.1 & 8.5 \\
\hline 24 & 10.6 & 9.3 & 7.5 & 10.7 & 11.9 & 15.7 & 16.6 & 16.9 & 14.8 & 12.4 & 10.3 & 8.8 \\
\hline 25 & 10.6 & -- & 7.6 & 10.8 & 12.2 & 16.3 & 16.3 & 17.1 & 14.8 & 12.4 & 10.2 & 8.4 \\
\hline 26 & 10.5 & 9.5 & 7.5 & 11.1 & 12.2 & 15.6 & 16.6 & 17.0 & 14.7 & 12.6 & ... & 7.9 \\
\hline 27 & 10.5 & 9.4 & 7.7 & 11.2 & 12.6 & 16.3 & 17.5 & 16.9 & 14.6 & 12.9 & --- & 7.8 \\
\hline 28 & 10.6 & 8.9 & 7.9 & 11.0 & 12.9 & 16.6 & 16.7 & 16.8 & 14.5 & 12.8 & -- & 8.1 \\
\hline 29 & -- & 8.5 & 8.1 & 10.8 & 12.7 & 16.5 & 16.8 & 16.5 & 14.4 & 12.1 & $\cdots$ & 8.0 \\
\hline 30 & ... & 8.0 & 7.7 & 11.0 & 12.7 & 15.8 & 17.0 & 16.6 & 14.3 & 11.8 & -..- & 8.7 \\
\hline 31 & --- & 8.1 & $\cdots$ & 11.1 & -. & 16.2 & 16.9 & --- & 14.2 & --- & $\cdots$ & 8.4 \\
\hline Mean & 10.7 & 9.6 & 7.1 & 9.9 & 11.9 & 14.9 & 16.8 & 16.8 & 15.3 & 13.1 & 10.6 & 8.6 \\
\hline $\begin{array}{l}\text { Max- } \\
\text { imum }\end{array}$ & 11.4 & 10.8 & 8.1 & 11.5 & 12.9 & 16.6 & 17.5 & 17.6 & 16.4 & 14.2 & 11.5 & 9.7 \\
\hline $\begin{array}{l}\text { Min- } \\
\text { mum }\end{array}$ & 10.4 & 8.0 & 5.9 & 7.8 & 10.8 & 12.9 & 16.3 & 16.0 & 14.2 & 11.8 & 10.1 & 7.8 \\
\hline
\end{tabular}


Table 28. Mean daily concentration of dissolved oxygen in water from the Cedar River, surface-water monitoring site, February 1, 1993, through January 31, 1994

[Dissolved-oxygen concentration given in milligrams per liter; -.., no data]

\begin{tabular}{|c|c|c|c|c|c|c|c|c|c|c|c|c|}
\hline Day & Feb. & Mar. & Apr. & May & June & July & Aug. & Sept. & Oct. & Nov. & Dec. & Jan. \\
\hline 1 & 12.0 & 14.6 & 10.4 & 9.7 & 9.3 & 7.0 & 6.2 & 7.7 & 11.1 & 14.8 & 14.0 & 13.9 \\
\hline 2 & 12.2 & 14.7 & 11.3 & 9.5 & 8.8 & 6.9 & 6.6 & 7.8 & 11.3 & 14.4 & 13.7 & 13.7 \\
\hline 3 & 12.1 & 15.2 & 11.9 & 9.2 & 8.7 & 6.7 & 6.7 & 8.0 & 11.5 & 14.1 & 13.5 & 13.3 \\
\hline 4 & 12.2 & 15.1 & 12.4 & 9.5 & 8.4 & 6.6 & 6.8 & 8.0 & 11.5 & 13.5 & 13.0 & 13.1 \\
\hline 5 & 12.3 & 14.4 & 12.2 & 9.8 & 8.4 & 6.7 & 7.1 & 8.0 & 11.5 & 12.6 & 12.7 & 13.1 \\
\hline 6 & 12.1 & 13.7 & 11.8 & 9.7 & 8.3 & 6.7 & 7.6 & 8.2 & 11.6 & 13.4 & 13.5 & 13.0 \\
\hline 7 & 12.2 & 12.9 & 11.3 & 9.1 & 8.0 & 6.8 & 7.8 & 8.6 & 11.3 & 14.3 & 14.5 & 12.9 \\
\hline 8 & 12.2 & 12.3 & 10.8 & 8.6 & 7.4 & 6.9 & 7.7 & 8.8 & 10.8 & 14.1 & 14.5 & 12.9 \\
\hline 9 & 12.3 & 11.9 & -- & 8.5 & 6.9 & 6.7 & 7.7 & 8.9 & 11.1 & 13.5 & 14.1 & 12.7 \\
\hline 10 & 12.3 & 12.1 & 10.7 & 8.4 & 6.7 & 6.3 & 6.9 & 9.1 & 10.5 & 12.7 & 13.8 & 12.5 \\
\hline 11 & 11.9 & 12.2 & 10.5 & 8.5 & 6.5 & 6.2 & 6.8 & 9.1 & 11.0 & 12.4 & 14.6 & 12.3 \\
\hline 12 & 11.2 & 12.8 & 10.7 & 8.4 & 6.4 & 6.2 & 7.0 & 9.1 & 11.5 & 11.7 & 14.9 & 12.1 \\
\hline 13 & 11.2 & 13.4 & 10.9 & 8.3 & 6.4 & 6.4 & 6.9 & 8.5 & 12.3 & 11.1 & 14.3 & 11.9 \\
\hline 14 & 11.8 & 13.7 & 11.0 & 8.2 & 6.3 & 6.5 & 6.7 & 8.1 & 12.3 & 11.1 & 13.8 & 11.8 \\
\hline 15 & -.- & 13.9 & 11.5 & 8.2 & 6.4 & 6.5 & 6.4 & 8.5 & 11.5 & 11.4 & 13.7 & 11.8 \\
\hline 16 & --- & 14.2 & 12.2 & 8.4 & 7.1 & 6.9 & 6.4 & 9.1 & 10.9 & 11.7 & 13.4 & 11.7 \\
\hline 17 & --- & 14.6 & 12.2 & 8.4 & 7.6 & 7.1 & 6.3 & 9.5 & 10.6 & 11.9 & 13.1 & 11.6 \\
\hline 18 & --- & 14.7 & 11.6 & -.- & 7.4 & 6.8 & 6.4 & 9.1 & 10.8 & 12.0 & ..- & 11.5 \\
\hline 19 & --. & 14.7 & 11.0 & --- & 7.2 & 6.8 & 6.1 & 8.9 & 10.9 & 11.9 & 12.9 & 11.3 \\
\hline 20 & --- & 14.6 & 10.9 & -- & 6.9 & 6.9 & 6.0 & 8.9 & 10.5 & 12.1 & 13.1 & 11.2 \\
\hline 21 & --. & 14.7 & 11.0 & --- & 7.2 & 6.9 & 6.2 & 8.9 & 11.3 & 12.2 & 13.8 & 11.0 \\
\hline 22 & --- & 15.0 & 10.8 & 9.3 & 7.1 & 6.9 & 6.4 & 8.8 & 12.1 & 12.0 & 14.4 & 10.7 \\
\hline 23 & $\cdots$ & 15.1 & 10.3 & 9.0 & 6.8 & 7.1 & 6.4 & 8.8 & 12.2 & 12.5 & 14.7 & 10.7 \\
\hline 24 & $\ldots$ & 14.6 & 9.8 & 9.0 & 6.5 & 7.2 & 6.9 & 9.6 & 12.2 & 12.4 & 14.9 & 10.7 \\
\hline 25 & $\cdots$ & 14.0 & 9.5 & 9.5 & 6.7 & 7.1 & 7.3 & 9.9 & 12.1 & 12.3 & 14.6 & 10.7 \\
\hline 26 & $\cdots$ & 12.9 & 9.4 & 9.8 & 6.9 & 7.0 & 7.1 & 9.9 & 11.4 & 13.1 & 14.2 & 10.9 \\
\hline 27 & 14.5 & 12.6 & 9.6 & 9.6 & 6.9 & 6.8 & 7.0 & 10.2 & 11.8 & 13.6 & 13.8 & 11.0 \\
\hline 28 & 14.5 & 11.7 & 9.8 & 8.6 & 6.9 & 6.6 & 7.0 & 10.5 & 12.9 & 13.9 & 13.8 & 11.0 \\
\hline 29 & --- & 10.9 & 9.8 & 8.1 & 7.1 & 6.4 & 7.2 & 11.1 & 13.4 & 14.1 & 14.0 & 11.1 \\
\hline 30 & --. & 9.9 & 9.9 & 8.6 & 7.0 & 6.5 & 7.2 & 11.1 & 13.9 & 14.0 & 14.4 & 11.2 \\
\hline 31 & --- & 9.2 & $\ldots$ & 9.0 & -. & 6.4 & 7.4 & --- & 14.6 & --. & 14.2 & 11.3 \\
\hline Mean & 12.3 & 13.4 & 10.9 & 8.9 & 7.3 & 6.7 & 6.8 & 9.0 & 11.7 & 12.8 & 13.9 & 11.9 \\
\hline $\begin{array}{l}\text { Max- } \\
\text { imum }\end{array}$ & 14.5 & 15.2 & 12.4 & 9.8 & 9.3 & 7.2 & 7.8 & 11.1 & 14.6 & 14.8 & 14.9 & 13.9 \\
\hline $\begin{array}{l}\text { Min- } \\
\text { imum }\end{array}$ & 11.2 & 9.2 & 9.4 & 8.1 & 6.3 & 6.2 & 6.0 & 7.7 & 10.5 & 11.1 & 12.7 & 10.7 \\
\hline
\end{tabular}


Table 29. Mean daily concentrations of dissolved oxygen in water from observation well CRM-4, February 1, 1993, through January 31, 1994

[Dissolved-oxygen concentration given in milligrams per liter; -.-, no data]

\begin{tabular}{|c|c|c|c|c|c|c|c|c|c|c|c|c|}
\hline Day & Feb. & Mar. & Apr. & May & June & July & Aug. & Sept. & Oct. & Nov. & Dec. & Jan. \\
\hline 1 & 5.2 & -.. & 0.8 & 5.2 & 2.4 & 0.9 & 1.9 & 0.2 & 4.3 & 5.4 & 9.9 & 11.0 \\
\hline 2 & 5.4 & ..- & .8 & 5.0 & 2.7 & .8 & 2.1 & .1 & 4.4 & 6.0 & 10.1 & 11.2 \\
\hline 3 & 5.8 & 9.7 & .8 & 4.8 & 2.5 & --- & 2.0 & .2 & 4.7 & 6.8 & 10.6 & 11.7 \\
\hline 4 & 6.4 & 7.9 & .8 & 4.3 & 1.9 & -.- & 1.4 & .3 & 5.1 & 7.7 & 11.0 & ... \\
\hline 5 & 6.0 & 8.9 & .8 & 3.9 & 1.5 & $\ldots$ & 2.0 & .4 & 5.1 & 8.5 & 11.0 & 11.5 \\
\hline 6 & 5.7 & 8.2 & .8 & 3.8 & 2.1 & .-. & 2.2 & 1.0 & 5.2 & 8.7 & 11.4 & 10.9 \\
\hline 7 & 5.7 & 6.6 & .7 & 3.5 & 2.4 & $\cdots$ & 2.2 & 1.3 & 5.2 & 8.4 & 11.3 & 10.2 \\
\hline 8 & 6.0 & 4.0 & .7 & 3.3 & 2.6 & -.. & 1.3 & 1.6 & 4.8 & 7.0 & 10.9 & 9.8 \\
\hline 9 & 6.1 & 1.1 & --. & 3.3 & 2.4 & -.. & 1.1 & 1.7 & 4.9 & 6.6 & 10.6 & 10.0 \\
\hline 10 & 5.8 & .8 & .8 & 3.1 & 1.7 & -- & 1.3 & --. & --- & 7.3 & 11.0 & 10.2 \\
\hline 11 & --- & .7 & .8 & 2.7 & 1.6 & --- & .9 & 1.5 & --. & 7.7 & 11.0 & 9.9 \\
\hline 12 & -- & .6 & 1.3 & 2.6 & 1.5 & -.. & 2.0 & 1.8 & --- & 7.6 & 10.9 & 9.7 \\
\hline 13 & 7.4 & .6 & 3.6 & 3.0 & .8 & --- & 1.9 & 2.0 & ... & 7.5 & 10.8 & 9.4 \\
\hline 14 & 6.8 & .6 & 3.8 & 2.3 & .7 & ... & .5 & 2.5 & 1.7 & 7.1 & 10.7 & 9.1 \\
\hline 15 & 6.4 & .5 & 4.8 & 1.2 & .7 & -.- & .2 & 3.2 & 1.6 & 6.7 & 10.6 & 8.6 \\
\hline 16 & 6.0 & .5 & 5.5 & 2.2 & 1.2 & --- & .2 & 3.2 & 1.9 & 6.0 & 10.6 & 8.3 \\
\hline 17 & 7.5 & .6 & ..- & 2.8 & .6 & .3 & .3 & 2.7 & 2.3 & 5.7 & 10.6 & 8.4 \\
\hline 18 & 8.8 & --. & -.- & 2.7 & .4 & .3 & .2 & 2.3 & 2.0 & 6.0 & 11.0 & --- \\
\hline 19 & 9.0 & 2.2 & --- & 3.1 & 1.7 & .3 & .5 & 3.1 & 1.2 & 6.5 & 11.1 & -.- \\
\hline 20 & 8.4 & 2.6 & --- & 3.0 & 2.0 & .3 & .2 & 3.8 & .6 & 6.5 & -.. & --. \\
\hline 21 & 9.5 & 4.2 & ... & 3.1 & 1.5 & .3 & .2 & 4.1 & .7 & 6.3 & 11.7 & $\ldots$ \\
\hline 22 & 9.0 & 4.5 & --- & 3.4 & .5 & .3 & .2 & 3.8 & .9 & 6.3 & 8.5 & 6.7 \\
\hline 23 & 6.8 & 3.8 & -.- & 4.0 & .4 & .3 & .2 & 3.7 & 1.1 & 6.9 & 4.8 & 6.5 \\
\hline 24 & 7.6 & 3.4 & 7.1 & 4.3 & .4 & .3 & .2 & --. & 1.4 & 7.6 & 7.7 & 6.4 \\
\hline 25 & 9.6 & 3.7 & 6.6 & 4.5 & .3 & .6 & .2 & 4.1 & 3.5 & 7.7 & 11.4 & 6.0 \\
\hline 26 & 9.4 & 3.8 & 6.1 & 4.5 & .3 & 1.2 & .2 & 4.4 & 4.8 & 7.6 & 11.9 & 5.7 \\
\hline 27 & 9.3 & 3.1 & 5.2 & 4.5 & .3 & 1.2 & .2 & 4.6 & 4.5 & 7.7 & 12.2 & 5.5 \\
\hline 28 & -.- & 2.0 & 4.5 & 5.1 & .4 & 1.4 & .2 & 4.4 & 4.9 & 7.8 & 12.3 & 5.3 \\
\hline 29 & --- & 1.0 & 4.2 & 4.7 & .4 & 2.6 & .2 & 4.2 & 4.4 & 8.2 & 12.0 & 5.0 \\
\hline 30 & $\ldots$ & .9 & 5.2 & 3.7 & .7 & 2.4 & .2 & 4.1 & 3.4 & 9.2 & 11.7 & 4.7 \\
\hline 31 & $\cdots$ & .9 & -.. & 2.7 & --- & 2.3 & .2 & --- & 4.6 & -- & 11.2 & 4.4 \\
\hline Mean & 7.2 & 3.1 & 3.0 & 3.6 & 1.3 & .9 & .9 & 2.5 & 3.3 & 7.2 & 10.7 & 8.3 \\
\hline $\begin{array}{l}\text { Max- } \\
\text { imum }\end{array}$ & 9.6 & 9.7 & 7.1 & 5.2 & 2.7 & 2.6 & 2.2 & 4.6 & 5.2 & 9.2 & 12.3 & 11.7 \\
\hline $\begin{array}{l}\text { Min- } \\
\text { imum }\end{array}$ & 5.2 & .5 & .7 & 1.2 & .3 & .3 & .2 & .1 & .6 & 5.4 & 4.8 & 4.4 \\
\hline
\end{tabular}


Table 30. Mean daily concentration of dissolved oxygen in water from municipal well Seminole 10, February 1, 1993, through January 31, 1994

[Dissolved-oxygen concentration given in milligrams per liter; --., no data]

\begin{tabular}{|c|c|c|c|c|c|c|c|c|c|c|c|c|}
\hline Day & Feb. & Mar. & Apr. & May & June & July & Aug. & Sept. & Oct. & Nov. & Dec. & Jan. \\
\hline 1 & 0.4 & $\ldots$ & -.. & 1.6 & 0.8 & $\cdots$ & 0.4 & 0.5 & 2.4 & 4.6 & 8.6 & 11.3 \\
\hline 2 & .4 & $\ldots$ & -.. & 1.3 & .7 & .5 & .4 & .5 & 2.5 & 4.2 & 8.5 & 11.5 \\
\hline 3 & .4 & 9.6 & $\ldots$ & 1.3 & .7 & .6 & .4 & .5 & 2.7 & 4.1 & 8.6 & 11.3 \\
\hline 4 & --- & 9.2 & ... & 1.2 & .7 & .6 & .4 & .5 & 2.9 & 4.3 & 8.9 & -- \\
\hline 5 & .6 & 9.2 & $\cdots$ & 1.2 & .6 & .6 & .4 & .5 & 3.1 & 4.9 & 9.4 & 11.0 \\
\hline 6 & .5 & 9.1 & ... & .9 & .6 & .6 & --. & .5 & 3.3 & 5.7 & 10.3 & 10.9 \\
\hline 7 & .5 & 8.8 & --- & 1.1 & .8 & .6 & 1.0 & .5 & 3.4 & 6.6 & 10.9 & 11.0 \\
\hline 8 & --- & 8.4 & -.- & 1.0 & .7 & .6 & 1.5 & .5 & 3.6 & 7.5 & 10.6 & 11.1 \\
\hline 9 & --- & 8.2 & ... & .9 & .7 & .6 & .7 & .5 & 3.8 & 7.4 & 10.5 & 11.1 \\
\hline 10 & .4 & 8.0 & 1.0 & .9 & .7 & .6 & .5 & .5 & 3.8 & 7.2 & 5.1 & 10.9 \\
\hline 11 & 2.5 & 7.2 & 1.0 & .9 & .7 & .6 & .5 & .4 & 3.9 & 7.0 & 4.0 & 10.6 \\
\hline 12 & 5.2 & 5.8 & .9 & .9 & .9 & .6 & .6 & .4 & 3.9 & 6.8 & 3.1 & 10.4 \\
\hline 13 & 6.4 & 4.0 & .9 & .9 & .7 & .6 & .7 & .4 & 3.8 & 6.7 & 2.5 & 10.1 \\
\hline 14 & 7.2 & 2.5 & .9 & .7 & .7 & .6 & .5 & .5 & 3.4 & 7.1 & 2.0 & 10.0 \\
\hline 15 & 7.5 & 1.8 & .9 & .7 & .7 & .6 & .6 & .4 & 3.1 & 7.7 & 1.6 & 9.8 \\
\hline 16 & 7.6 & 1.4 & .9 & .7 & .7 & .9 & .5 & .4 & 2.9 & 8.0 & 1.4 & 9.8 \\
\hline 17 & 4.6 & 1.2 & .9 & .6 & .7 & .7 & .4 & .4 & 2.7 & 7.9 & 1.2 & ..- \\
\hline 18 & 4.2 & 1.4 & .8 & .7 & .6 & .7 & .4 & .4 & 2.8 & 7.8 & 1.2 & $\cdots$ \\
\hline 19 & 2.6 & 1.3 & .8 & .7 & .6 & .6 & .4 & .5 & 3.2 & 7.6 & 1.1 & $\cdots$ \\
\hline 20 & 1.9 & 1.2 & .8 & .7 & .6 & .6 & .4 & .5 & 3.3 & 7.4 & 1.0 & ... \\
\hline 21 & 7.1 & 1.5 & .9 & .7 & .6 & .5 & .4 & .6 & 3.0 & 7.2 & 5.6 & $\ldots$ \\
\hline 22 & 6.3 & 2.1 & 1.2 & .7 & .6 & .5 & .4 & 1.0 & 2.6 & 6.9 & 9.8 & 7.6 \\
\hline 23 & 6.0 & 3.0 & 1.4 & .7 & .6 & .5 & .4 & 1.3 & 2.4 & 7.2 & 9.7 & 7.4 \\
\hline 24 & 6.9 & 3.9 & 1.7 & .7 & .6 & .5 & -.- & 1.5 & 2.5 & 7.4 & 9.5 & 7.1 \\
\hline 25 & 7.8 & 4.5 & 1.9 & .7 & .6 & .5 & .5 & 1.7 & 2.7 & 7.6 & 8.6 & 6.9 \\
\hline 26 & 7.8 & 5.0 & 2.0 & .7 & .6 & .5 & .5 & 1.8 & 3.1 & 7.8 & 7.5 & 6.8 \\
\hline 27 & ..- & ... & 2.1 & .7 & .6 & .5 & .5 & 1.9 & 3.8 & 8.0 & 6.7 & 6.7 \\
\hline 28 & --. & $\cdots$ & 2.3 & .7 & .6 & .5 & .5 & 2.0 & 4.5 & 8.3 & 7.0 & 6.6 \\
\hline 29 & $\ldots$ & $\ldots$ & 2.2 & .7 & .6 & .5 & .5 & 2.3 & 4.7 & 8.5 & 7.8 & 6.4 \\
\hline 30 & --- & -- & 2.0 & .7 & $\cdots$ & .5 & .5 & 2.4 & 4.9 & 8.6 & 9.3 & 6.2 \\
\hline 31 & --- & -. & ... & .8 & -- & .5 & .5 & -.- & 4.9 & ... & 10.6 & 6.0 \\
\hline Mean & 4.1 & 4.9 & 1.3 & .9 & .7 & .6 & .5 & .9 & 3.3 & 6.9 & 6.5 & 9.1 \\
\hline $\begin{array}{l}\text { Max- } \\
\text { imum }\end{array}$ & 7.8 & 9.6 & 2.3 & 1.6 & .9 & .9 & 1.5 & 2.4 & 4.9 & 8.6 & 10.9 & 11.5 \\
\hline $\begin{array}{l}\text { Min- } \\
\text { imum }\end{array}$ & .4 & 1.2 & .8 & .6 & .6 & .5 & .4 & .4 & 2.4 & 4.1 & 1.0 & 6.0 \\
\hline
\end{tabular}


Table 31. Mean daily concentrations of dissolved oxygen in water from observation well CRM-3, February 1, 1993, through January 31, 1994

[Dissolved-oxygen concentration given in milligrams per liter; ---, no data]

\begin{tabular}{|c|c|c|c|c|c|c|c|c|c|c|c|c|}
\hline Day & Feb. & Mar. & Apr. & May & June & July & Aug. & Sept. & Oct. & Nov. & Dec. & Jan. \\
\hline 1 & --- & -.. & 0.5 & 0.6 & 0.4 & ..- & 0.3 & 0.4 & 0.3 & 0.3 & 0.3 & 0.3 \\
\hline 2 & -.- & -.. & .5 & .5 & .4 & 0.9 & .3 & .4 & .3 & .3 & .3 & .3 \\
\hline 3 & --- & 0.8 & .5 & .5 & -.- & .4 & .3 & .4 & .3 & .3 & .2 & .3 \\
\hline 4 & -.. & .4 & .5 & .5 & --- & .4 & .3 & .4 & .3 & --. & .2 & --- \\
\hline 5 & -.. & -.- & .4 & .5 & .5 & .4 & .3 & .4 & .3 & .3 & .2 & 1.0 \\
\hline 6 & --- & -.- & .4 & .5 & .4 & .4 & --. & .4 & .3 & .3 & --- & .6 \\
\hline 7 & -.- & $\ldots$ & .4 & .5 & .4 & .4 & .3 & .4 & .3 & .3 & .3 & .5 \\
\hline 8 & --- & --. & .4 & .5 & .4 & .4 & .4 & .4 & .3 & .3 & .3 & .4 \\
\hline 9 & --. & -.- & $\ldots$ & .5 & .4 & .4 & .3 & .4 & .3 & .3 & .3 & .4 \\
\hline 10 & 3.1 & .4 & --- & .5 & .4 & .4 & .3 & -.. & .3 & .2 & .3 & .3 \\
\hline 11 & 2.4 & .4 & .5 & .5 & .4 & .4 & .3 & .4 & .3 & .3 & .3 & .3 \\
\hline 12 & 1.1 & .3 & .5 & .5 & .4 & .4 & .3 & .3 & .3 & .3 & .3 & .3 \\
\hline 13 & .3 & .3 & .5 & .4 & .4 & .4 & .3 & .4 & --. & .3 & .3 & .3 \\
\hline 14 & .2 & .3 & .5 & .4 & .4 & .4 & .3 & .4 & .3 & .3 & .3 & .3 \\
\hline 15 & .2 & .4 & .5 & .4 & .4 & .4 & .3 & .4 & .3 & .3 & .3 & .3 \\
\hline 16 & .2 & .4 & .5 & .4 & --. & --- & .3 & .3 & .4 & .3 & .3 & .3 \\
\hline 17 & .4 & .4 & .5 & .4 & --. & .5 & .3 & .3 & .4 & .3 & .3 & .3 \\
\hline 18 & -.- & --- & .5 & -.. & .4 & .4 & .3 & .3 & .4 & .3 & $\ldots$ & .3 \\
\hline 19 & --- & --. & .5 & --. & .4 & .4 & .3 & .3 & .4 & .3 & .4 & .3 \\
\hline 20 & .6 & .4 & .5 & .5 & .4 & .4 & .3 & .3 & .4 & .3 & -.. & .3 \\
\hline 21 & .6 & .4 & .5 & .5 & .4 & .4 & .3 & .3 & .4 & .3 & .4 & -.. \\
\hline 22 & .5 & .4 & .5 & .5 & .4 & .4 & .3 & .3 & .3 & .3 & .4 & .2 \\
\hline 23 & .5 & .4 & --- & .5 & .4 & .4 & .3 & .3 & .3 & $\ldots$ & .3 & .3 \\
\hline 24 & .5 & .4 & .8 & .5 & --. & .4 & ..- & --- & .4 & -.. & .3 & .3 \\
\hline 25 & .5 & --- & .7 & .5 & .4 & .4 & .4 & .4 & .4 & .2 & .3 & .3 \\
\hline 26 & .5 & -.- & .6 & .4 & .4 & .4 & .4 & .3 & .3 & .2 & .3 & .3 \\
\hline 27 & --- & 1.9 & .6 & .4 & .4 & .4 & .4 & .3 & .3 & .3 & .3 & .3 \\
\hline 28 & ... & 1.4 & .6 & .4 & .4 & .4 & .4 & .3 & --. & .2 & .3 & .3 \\
\hline 29 & ..- & .8 & .6 & .4 & .4 & .4 & .4 & .3 & .3 & .3 & .3 & .3 \\
\hline 30 & $\ldots$ & .5 & .6 & .4 & .4 & .4 & .4 & .3 & .3 & .3 & .3 & .3 \\
\hline 31 & -.. & .5 & --- & .4 & --- & .3 & .4 & -.. & .3 & --. & .3 & .2 \\
\hline Mean & .8 & 6 & .5 & .5 & .4 & .4 & .3 & .3 & .3 & .3 & .3 & .3 \\
\hline $\begin{array}{l}\text { Max- } \\
\text { imum }\end{array}$ & 3.1 & 1.9 & .8 & .6 & .5 & .9 & .4 & .4 & .4 & .3 & .4 & 1.0 \\
\hline $\begin{array}{l}\text { Min- } \\
\text { imum }\end{array}$ & .2 & .3 & .4 & .4 & .4 & .3 & .3 & .3 & .3 & .2 & .2 & .2 \\
\hline
\end{tabular}


Table 32. Mean daily concentrations of dissolved oxygen in the water from the Cedar Rapids municipal watertreatment plant, February 1, 1993, through January 31, 1994

[Dissolved-oxygen concentration given in milligrams per liter; ---, no datal

\begin{tabular}{|c|c|c|c|c|c|c|c|c|c|c|c|c|}
\hline Day & Feb. & Mar. & Apr. & May & June & July & Aug. & Sept. & Oct. & Nov. & Dec. & Jan. \\
\hline 1 & --. & 0.7 & 0.6 & 1.5 & 1.4 & 1.1 & 8.8 & 1.0 & 1.1 & 1.3 & 2.7 & --- \\
\hline 2 & -.. & .7 & .6 & 1.2 & 1.4 & 1.1 & 8.8 & 1.0 & 1.0 & 1.3 & 2.7 & -.. \\
\hline 3 & --. & .5 & .7 & 1.2 & 1.4 & 1.1 & 8.4 & 1.0 & .9 & 1.3 & 2.7 & -- \\
\hline 4 & -.- & .6 & 1.4 & 1.3 & 1.4 & 1.0 & 8.2 & .9 & 1.0 & 1.3 & 2.7 & -.- \\
\hline 5 & --- & .7 & .9 & 1.3 & 1.4 & .9 & 8.1 & .9 & 1.1 & 1.2 & 2.7 & 2.8 \\
\hline 6 & --. & .7 & .6 & 1.2 & 1.4 & 1.0 & --- & .9 & 1.0 & 1.2 & -.. & 2.7 \\
\hline 7 & ..- & .7 & --- & 1.4 & 1.4 & 1.0 & 1.1 & .9 & 1.0 & 1.2 & 1.7 & 2.5 \\
\hline 8 & -.. & .7 & --- & 1.5 & 1.5 & --- & 1.0 & .9 & 1.0 & 1.2 & 1.8 & 2.6 \\
\hline 9 & --- & .8 & $\cdots$ & 2.9 & 1.5 & -- & 1.1 & .9 & .8 & 1.3 & 1.7 & 2.8 \\
\hline 10 & --- & --- & 1.5 & 3.0 & 1.7 & $\cdots$ & 1.0 & .9 & .8 & 1.8 & 1.7 & 2.8 \\
\hline 11 & --- & 1.1 & 1.4 & 2.9 & 1.6 & --- & 1.0 & .9 & .8 & 3.2 & 1.7 & 2.5 \\
\hline 12 & -.- & 1.0 & 1.4 & 2.8 & 1.5 & --- & 1.0 & 1.0 & .8 & 3.6 & 1.6 & 2.4 \\
\hline 13 & --- & 1.0 & 1.2 & 2.9 & 1.4 & --- & 1.0 & 1.0 & 1.1 & 3.7 & 1.7 & 2.4 \\
\hline 14 & --- & 1.0 & 1.0 & 2.6 & 1.4 & --- & .9 & .8 & 1.4 & 3.9 & 1.5 & 2.9 \\
\hline 15 & -.- & .9 & .8 & 2.0 & 1.4 & --- & .9 & .8 & 1.4 & 3.5 & 1.6 & 2.4 \\
\hline 16 & -- & .9 & .8 & 2.0 & 1.3 & -- & .9 & .8 & 1.3 & 3.7 & 1.6 & 2.3 \\
\hline 17 & 0.7 & 1.0 & .7 & 2.3 & 1.4 & 11.2 & .9 & .8 & 1.5 & 3.2 & 1.6 & 2.5 \\
\hline 18 & 1.3 & .9 & 1.0 & 2.5 & 2.9 & 10.3 & .8 & .8 & 1.5 & 2.5 & --. & 2.9 \\
\hline 19 & 1.1 & .9 & 1.4 & 2.4 & 3.1 & 10.6 & .8 & .8 & 1.4 & 2.6 & 2.3 & 2.6 \\
\hline 20 & .9 & .9 & 1.4 & 2.6 & 3.9 & 10.7 & .8 & .8 & 1.4 & 2.7 & 2.4 & 2.5 \\
\hline 21 & .8 & .8 & 1.4 & --- & 3.1 & 10.7 & .8 & .8 & 1.3 & 2.8 & 2.6 & ... \\
\hline 22 & .7 & .8 & 1.4 & 1.6 & 3.9 & 10.1 & .8 & .8 & 1.3 & 2.7 & 2.6 & 2.3 \\
\hline 23 & .8 & .7 & 1.5 & 1.6 & 4.5 & 9.7 & .8 & 1.0 & 1.2 & --- & 2.5 & 2.8 \\
\hline 24 & .7 & .7 & 1.6 & 1.5 & 3.8 & 9.0 & .9 & 1.2 & 1.1 & 2.5 & 2.5 & 2.7 \\
\hline 25 & .4 & --- & 1.6 & 1.5 & 2.1 & 9.3 & 1.1 & 1.3 & 1.1 & 2.2 & 2.4 & 2.5 \\
\hline 26 & --- & .8 & 1.6 & 1.5 & 1.3 & 9.8 & 1.1 & 1.3 & 1.1 & 2.4 & -.- & 2.8 \\
\hline 27 & .6 & .9 & --- & 1.6 & 1.2 & 9.5 & 1.1 & 1.4 & 1.0 & 2.4 & $\cdots$ & 2.9 \\
\hline 28 & .9 & 1.3 & 1.6 & 1.7 & 1.2 & 9.4 & 1.0 & 1.1 & 1.2 & 2.3 & --. & 2.9 \\
\hline 29 & $\cdots$ & 1.3 & 1.4 & 1.7 & 1.2 & 9.8 & 1.0 & 1.1 & 1.5 & 2.4 & --- & 2.8 \\
\hline 30 & --. & 1.1 & 1.4 & 1.5 & 1.2 & 9.3 & 1.0 & 1.1 & 1.4 & 2.4 & --- & 1.9 \\
\hline 31 & --- & .8 & --- & 1.5 & --- & 8.6 & 1.0 & --- & 1.3 & --- & --- & 2.2 \\
\hline Mean & .8 & .9 & 1.2 & 1.9 & 1.9 & 7.1 & 2.2 & 1.0 & 1.2 & 2.3 & 2.1 & 2.6 \\
\hline $\begin{array}{l}\text { Max- } \\
\text { imum }\end{array}$ & 1.3 & 1.3 & 1.6 & 3.0 & 4.5 & 11.2 & 8.8 & 1.4 & 1.5 & 3.9 & 2.7 & 2.9 \\
\hline $\begin{array}{l}\text { Min- } \\
\text { imum }\end{array}$ & .4 & .5 & .6 & 1.2 & 1.2 & .9 & .8 & .8 & .8 & 1.2 & 1.5 & 1.9 \\
\hline
\end{tabular}


Table 33. Numerical range of each primary bio-indicator (particulates) counted per 100 gallons of water [EH, extremely heavy; H, heavy; M, moderate; R, rare; NS, not significant, >, greater than; <, less than; from Vasconcelos and Harris (1992)]

\begin{tabular}{lccccc}
\hline $\begin{array}{c}\text { Indicators for } \\
\text { surface water }\end{array}$ & EH & H & M & R & NS \\
\hline Giardia $^{2}$ & $>30$ & $16-30$ & $6-15$ & $1-5$ & $<1$ \\
Coccidia $^{2}$ & $>30$ & $16-30$ & $6-15$ & $1-5$ & $<1$ \\
Diatoms $^{\text {Other algae }}$ & $>150$ & $41-149$ & $11-40$ & $1-10$ & $<1$ \\
Insects/larvae $_{\text {Rotifers }}^{>300}$ & $96-299$ & $21-95$ & $1-20$ & $<1$ \\
Plant debris $^{3}$ & $>100$ & $31-99$ & $16-30$ & $1-15$ & $<1$ \\
\hline
\end{tabular}

\footnotetext{
${ }^{1}$ According to U.S.Environmental Protection Agency, 1991, Guidance manual for compliance with the filtration and disinfection requirements for public water systems using surface-water sources, Washington D.C.

${ }^{2}$ If Giardia cysts or coccidia are found in any sample, irrespective of volume collected, score as though the sample was counted per 100 gallons.

${ }^{3}$ Chlorophyll containing.
}

Table 34. Relative surface-water risk factors associated with scoring of primary bio-indicators (particulates) present during microscopic particulate analysis of water from the study area [EH, extremely heavy; H, heavy; M, moderate; R, rare; NS, not significant; from Vasconcelos and Harris (1992)]

\begin{tabular}{lccccc}
\hline \multicolumn{1}{c}{$\begin{array}{l}\text { Indicators for } \\
\text { surface water }\end{array}$} & EH & H & M & R & NS \\
\cline { 2 - 6 } \multicolumn{1}{c}{ Giardia } & 40 & 30 & 25 & 20 & 0 \\
Coccidia & 35 & 30 & 25 & 20 & 0 \\
Diatoms & 16 & 13 & 11 & 6 & 0 \\
Other algae & 14 & 12 & 9 & 4 & 0 \\
Insects/larvae & 9 & 7 & 5 & 3 & 0 \\
Rotifers & 4 & 3 & 2 & 1 & 0 \\
Plant debris & 3 & 2 & 1 & 0 & 0 \\
\hline
\end{tabular}

1 According to U.S. Environmental Protection Agency, 1991, Guidance manual for compliance with the filtration and disinfection requirements for public water systems using surface-water sources, Washington D.C.

2 Risk of surface-water contamination: greater than or equal to 20 , high risk; 10-19, moderate risk; 0-9 low risk. 